\author{
UNIVERSIDADE DE SÃO PAULO \\ FACULDADE DE FILOSOFIA LETRAS E CIÊNCIAS HUMANAS \\ DEPARTAMENTO DE LITERATURA BRASILEIRA
}

\title{
Presenças de Orfeu
}

Tese de Doutorado em Letras (Literatura Brasileira), apresentada ao Departamento de Letras Clássicas e Vernáculas da Faculdade de Filosofia, Letras e Ciências Humanas da Universidade de São Paulo, sob a orientação do Prof. Dr. Alcides Celso de Oliveira Villaça.

MARIA CLAUDETE DE SOUZA OLIVEIRA

São Paulo

2006 
Para Olivier e meus pais: Luiz e Luíza. 
Agradeço, especialmente:

Aos professores Murilo Marcondes de Moura, Joaquim Alves de Aguiar, Roberto Daud, Raquel Illescas Bueno e José Miguel Wisnik pela leitura atenciosa, sugestões e críticas feitas, seja no exame de qualificação e/ou na defesa desta tese - que me motivaram a fazer os ajustes no texto, inclusive, depois da defesa -, pela gentileza do empréstimo de livros e cessão de cópias de textos importantes para o desenvolvimento deste trabalho;

A minha irmã Claudinete que, por uma gentileza, gerou o acaso, origem do tema desta tese e pela prontidão providencial, sua e de minha sobrinha, Claudia;

Às amigas que, mesmo reclamando minha ausência, não deixaram de estar por perto ou à disposição: Cecília, Cláudia, Elisabeth, Marcy, Marta, Rosana e Rosely;

Aos meus colegas de pós-graduação, desde a época do mestrado: Alexandre, Ana Luíza, André, Fernando, leda, Salete, Mário, Raquel, Rejane (a quem agradeço também pelas conversas iluminadas e tanto mais), a Cilaine, Maria Salete e Cristiane, que conheci depois - todos de alguma forma sempre afetuosamente presentes -, pelas indicações bibliográficas, os empréstimos de livros e de gravação de cursos, a preocupação e o incentivo;

A Antonio Edson, pelas indicações bibliográficas, a Letícia, pelo empenho em conseguir uma cópia do filme Orfeu, de Diegues, aparentemente inexistente no mercado; ao senhor Jacob Lebensztayn, pela leitura atenciosa da tese; A Josenildo Forte Brito, pela tradução de resenhas do New York Times;

A Flávio Peralta e Marcelo, por, no último momento, terem vertido este trabalho em $P D F$, nova exigência dos tempos modernos;

Ao CNPQ, pelo apoio financeiro para a realização desse trabalho;

A Alcides, pela cumplicidade generosa e observações críticas, marcas de sua presença neste trabalho. 
Os mitos devolvem aos homens os seus próprios conflitos; como metáforas, eles "desempenham sua função de falar" aos "níveis profundos do ser humano". Com o correr do tempo, essas figuras de linguagem podem ir perdendo a capacidade de serem absorvidas, mas os artistas, "de acordo com suas disciplinas e artes", fazem-nas emergir "do contexto contemporâneo da experiência".

Partindo dessas premissas, foram feitas e em seguida confrontadas as análises dos poemas "Legado" e "Canto órfico", de Carlos Drummond de Andrade; da peça,"Orfeu da Conceição: Uma tragédia carioca, de Vinícius de Moraes e dos dois filmes baseados nela: Orfeu negro, de Marcel Camus e Orfeu, de Carlos Diegues.

Num primeiro momento, diferenciando-se do Orfeu de Drummond - que se define e define o que vê, mais próximo, talvez, do caráter apolíneo do mito - o Orfeu de Vinícius promove, ou deseja promover a dissolução dionisíaca das diferenças, inclusive sociais, sugerida pela figura do cantor do morro: Orfeu da Conceição; mas, aproximando-nos mais um pouco dessas retomadas, sem que a primeira impressão deixe de existir, podemos observar também a expressão "dionisíaca" do primeiro autor, assim como a expressão "apolínea" do segundo e, comum a estas duas expressões, a crença no valor artístico da poesia e do canto.

A presença de Orfeu nos filmes de Marcel Camus e de Carlos Diegues (que, como na peça, atualizam o mito em uma favela, na mesma década da estréia da peça, e quarenta anos depois dela, respectivamente) confirma a capacidade do canto e da arte de transformar a "agonia em elegia"1, como fizeram Carlos Drummond de Andrade e Vinícius de Moraes.

Palavras-chave: Orfeu, Carlos Drummond de Andrade, Vinícius de Moraes, Poesia, Canção.

\footnotetext{
1 Uso aqui a expressão de Otto Maria Carpeaux, ao analisar a poesia de Drummond. em "Fragmento sobre Carlos Drummond de Andrade". Origens e fins. Rio de Janeiro: Casa do Estudante, 1943.
} 


\section{Summary}

Myths are giving back to mankind their own conflicts. As metaphor "they play their role" to talk "to the deep levels of mankind". As time goes by, these language figures can loose their absorption capacity but artists "in accordance with their disciplines and arts" are reviving them "in the contemporary context of experience".

Starting from this observation, an analysis and a comparison of the following works are done : "Legado" \& "Canto orfico", poems from Carlos Drummond de Andrade, "Orfeu da conceiçao, a Carioca tragedy "from Vinícius de Moraes and two movies "Orfeu Negro" from Marcel Camus \& "Orfeu do Carnaval” from Carlos Diegues.

The first impression in Vinícius' Orfeo is that he promotes or wants to promote the Dionisyac dissolution of differences suggested by the singer on the "morro"*: Orfeu da Concecao. This first impression is different in Drummond's Orfeo who defines himself and defines what he sees as closer perhaps to the Apollinic character of the myth.

But getting closer to Orfeu's remake one can observe the Drummond Dionisyac expression as well as the Appolinic expression of Vinícius inverting the first impression but keeping in both the ethical feeling in front of the indifferent world to myth and the belief in the value of poetry and songs.

The presence of Orfeu in the movies of Marcel Camus and Carlos Diegues which as in the play are bringing up to date the myth in a "favela"**, during the same decade of the play and forty years later respectively, are confirming the capacity of songs and art to transform "agony in elegy" as Carlos Drummond de Andrade and Vinícius de Moraes did with their works

Key words: Orfeu, Carlos Drummond de Andrade, Vinícius de Moraes, poem, song.

1 * Morro : Rio de Janeiro hills

$2^{* *}$ Favela : slums 
ÍNDICE

Introdução

Cap. I Orfeu: O mito de Orfeu

1- A recorrência aos mitos ……......................................................... 13

2- O mito de Orfeu .......................................................................... 20

Cap. II Que lembrança darei?

1- Análise de "Legado"...................................................................... 37

2- Análise de "Canto órfico",............................................................... 56

Cap. III O vivo encontro entre o erudito e o popular

1- "O morro é Orfeu", análise de Orfeu da Conceição ................................. 81

2- "Agora eu sou Orfeu", análise de Orfeu negro, de Marcel Camus............ 120

3- "O Rei do Carnaval", análise de Orfeu, de Carlos Diegues....................... 141

4- Presenças de Orfeu..........................................................................149

5- Dialogando com outras críticas e depoimentos .....................................154

6- Orfeu é Vinícius (" o branco mais preto do Brasil “) .................................. 166

Cap. IV Presenças de Orfeu: Vinícius e Drummond .........................................169

Anexos: 1- Trechos de correspondências, entrevistas e relatos envolvendo os dois poetas: Carlos Drummond de Andrade e Vinícius de Moraes. 175

Bibliografia 185 
Introdução

O presente estudo derivou de um fato ocasional associado a um interesse antigo, vindo de uma leitura de "O sol de Homero"2. O acaso trouxe um comentário sobre o filme Orfeu negro, do francês Marcel Camus, baseado em Orfeu da Conceição, peça de Vinícius de Moraes. O filme, ganhador do Oscar em 1960, teria originado "o primeiro reconhecimento do Brasil, no exterior, depois do futebol e Carnaval".

O comentário vinha de um cantor e compositor de canções, famoso no Brasil e em países do exterior, quando recebia o troféu pela canção tema de Orfeu, de Carlos Diegues, nova adaptação cinematográfica da peça de Vinícius. Era Caetano Veloso. O texto, que parte da constatação da leitura errônea de Homero, obstáculo para uma compreensão profícua de sua obra, é de Otto Maria Carpeaux, nascido na Áustria em 1900, de uma erudição plena de vida, que chegou ao Brasil, fugindo da guerra, em 1940, ativo participante da evolução da crítica literária brasileira, que encontrou aqui "uma literatura e especialmente uma poesia de valor próprio, expressão original de grandes poetas, que representam uma nação, uma tradição"3.

No texto, Carpeaux reclamava a banalização a que fora submetida a obra de Homero e todos os mitos descritos nela. Neste processo, encobrira-se a complexidade do mundo grego reduzida a uma espécie de história em quadrinhos das escolas elementares. O mundo passava a considerar Homero uma leitura entediante. Compreendê-lo não significaria apenas conhecer os gregos, mas penetrar na experiência da origem mesma dos valores primordiais, contida nos mitos, como amor, ódio, compaixão, temor, que independente de época ou lugar atingem todos os homens.

\footnotetext{
${ }^{2}$ Carpeaux, Otto Maria. "O sol de Homero", in: Origens e fins. Rio de Janeiro: Casa do Estudante, 1943, p. 331-2.

${ }^{3}$ Idem, "Estúdios sobre la poesia brasilenã", in: Cuadernos americanos: La revista del nuevo mundo. (México). Ano 5, v. $3^{\mathrm{O}}$, n.6, nov-dez. 1946.
} 
Da antiga leitura, ficara em mim, principalmente, a relevância sublinhada por Otto Maria Carpeaux da aretê grega. O termo relaciona-se ao processo de auto-educação deste povo, para o qual a poesia de Homero era tomada como "Bíblia". Havia identidade entre a figura do homem ideal expresso nas duas epopéias e a do homem grego; os princípios éticos estavam identificados a um forte vínculo com a natureza, a um aprimoramento individual que contemplava o mundo do qual esse homem se sentia parte. Neste individualismo havia uma conformidade consciente com a Natureza e com o Cosmos, compreendido como indivíduo absoluto.

"O sol de Homero", primeiro ensaio de Origens e fins, antecipa o problema da compreensão de poesia, sobre o qual Carpeaux tratará no ensaio seguinte "Poesia e ideologia" - em que a ideologia é definida como responsável pela má compreensão de poesia, contra a qual, na contramão, sempre reage a "verdadeira poesia".

Acreditando nessa força do mito como capaz de ser recuperada pela obra artística, e que esta, por sua vez é, capaz de subverter a própria ideologia da época, como faz toda "verdadeira poesia", considerei que a peça de Vinícius e as retomadas dela pelos dois cineastas fariam conhecer algo do mito de Orfeu, nestas épocas, como também deixar ver algo sobre o Brasil ou sobre os autores expresso por essas obras.

Orfeu da Conceição, de Vinícius de Moraes, começou a ser escrita em 1942 e foi terminada em 53. Um pouco depois, mas ainda na mesma década, estréiam a peça Orfeu da Conceição (1956), no Teatro Municipal do Rio de Janeiro, e o filme Orfeu negro, com a direção do diretor francês Marcel Camus e roteiro baseado no texto de Vinícius (1959). Quarenta anos depois, estréia outro filme baseado na mesma peça de teatro: Orfeu, dirigido por Carlos Diegues.

Chamou minha atenção o fato de o mito de Orfeu estar "envolvido" naquele reconhecimento. Passados mais de 40 anos de sua estréia, "Orfeu negro" é 
lembrado ainda hoje com entusiasmo, no exterior, onde vez por outra é reapresentado pela TV e por mostras de cinema. Qual seria a relação entre Orfeu - o cantor que desce aos infernos à procura da amada, que dominava pelo encanto tanto animais ferozes como a própria natureza, o mortal tão próximo a Apolo e Dionísio - e este reconhecimento, no começo da década de 60? Por que Orfeu apareceria outra vez, passadas mais de quatro décadas, em outra adaptação da peça do poeta e compositor Vinícius de Moraes? A importância da canção popular brasileira poderia ser uma resposta, mas ela só fez aguçar ainda mais as primeiras questões.

Além de Vinícius, vários outros poetas brasileiros fazem alusão a Orfeu. Jorge de Lima, com Invenção de Orfeu, é o primeiro a ser lembrado; Murilo Mendes, Cecília Meirelles, Mário Faustino etc... juntam-se ao poeta cantor nesta recorrência. Entre eles, Carlos Drummond de Andrade.

Em 1951, Carlos Drummond de Andrade publica Claro enigma, e em 1954 Fazendeiro do ar, o primeiro livro traz "Legado", o segundo, "Canto órfico", dois poemas com referência direta a Orfeu, praticamente contemporâneos à peça e ao filme observados. A leitura desses poemas vinha de início como um contraponto ao que, no início, parecia ser uma visão demasiado romântica do mito, tanto de Vinícius de Moraes, quanto do cineasta Marcel Camus, mas, no decorrer do trabalho, o contraponto foi se transformando em diálogo que contestava as primeiras impressões. O enigmático "Canto órfico" levou-me à sugestão da modernidade como uma "falha" penetrando necessariamente a ideal harmonia escultural apolínea. A significação deste texto para as análises que eu vinha fazendo ganhou em vigor com a leitura de Passos de Drummond ${ }^{4}$, de Alcides Villaça, sobretudo pelo ensaio sobre "A máquina do Mundo", em que o embate entre o caráter "épico", representado pela máquina, é contraposto à consciência lírica do poeta frente ao mundo. A isso, juntaram-se os comentários do prof.

\footnotetext{
${ }^{4}$ São Paulo: Cosak \& Naify, 2006.
} 
Carlos Felipe Moisés ${ }^{5}$ sobre a incorporação da canção popular transpondo também os poemas clássicos de Vinícius, sobretudo os sonetos, principalmente a partir de Orfeu da Conceição.

Num primeiro momento, diferenciando-se do Orfeu de Drummond - que se define e define o que vê, mais próximo, talvez, do caráter apolíneo do mito - o Orfeu de Vinícius promove, ou deseja promover a dissolução dionisíaca das diferenças, sugerida pela figura do cantor do morro: Orfeu da Conceição; porém, aproximando-nos mais um pouco dessas retomadas do mito de Orfeu podemos acrescentar, sem negar as primeiras observações, a expressão "dionisíaca" dos poemas do poeta mineiro, assim como a expressão apolínea também presente na tragédia escrita pelo poeta carioca. Comum às retomadas, como eco da positividade de Orfeu, encontramos nessas obras o sentimento ético, fomentando a crença no valor da poesia, como expressão de desejo de transformação.

Ao mesmo tempo em que Drummond expõe a carência do mundo, que nega Orfeu, sua luta com as palavras expõe a carência das próprias palavras, que desde sua origem, por ironia das ironias, também "sugerem o que deveria ser, como se já fosse, embora não seja" necessitando do trabalho poético ${ }^{6}$. A poesia a ser feita deve suprir esta carência, promover a possibilidade de penetrar por essa fresta entre a cultura e o que veio antes dela, entre a palavra e o que a originou; entre nós e os mitos. É preciso trazer a chave. Ao poeta caberia lembrar a identidade entre homem e natureza sugerida pelos mitos, mesmo que pela alusão.

Essa luta entre o poeta e o mundo, cujo diálogo com o mito descobre um sentimento ético expresso pela arte (que já estava em Homero), está em "Canto órfico", em "Legado", e - aproximando Drummond a Vinícius -, está em Orfeu da Conceição, quando a canção popular atravessa a tragédia carioca.

\footnotetext{
${ }^{5}$ Aula ministrada na Casa do Saber, em maio de 2006, no curso Do sublime ao cotidiano: a trajetória poética de Vinícius de Moraes.

${ }^{6}$ A definição de ironia é dada por Anatol Rosenfeld citando de memória a frase que ele acredita ser de Bergson. A relação entre a ironia e a origem das palavras é feita por Anatol: " [...]Mas essa capacidade de distanciamento [da ironia, que sugere o que deveria ser como se já fosse, embora não seja] em face ao imediatamente vivido, pensado e experimentado, presidira a própria origem da língua humana. É graças a esta capacidade que os sons emitidos se transformam de mero sinal em símbolo" Cf.: "Thomas Mann: Apolo, Hermes, Dionísio", in: Texto e contexto. São Paulo: Perspectiva, $3^{\circ}$ ed., 1976 , p. 206
} 
A peça de Vinícius de Moraes, Orfeu da Conceição, ambienta o destino trágico de Orfeu e Eurídice, em pleno Carnaval, em uma favela do Rio de Janeiro. Apesar de ter como centro a celebração do amor, lembrando o tom romântico do século XIX, parte de um processo bastante vivo, principalmente, a partir da década de 30, com a divulgação do pensamento de Gilberto Freire, a literatura de escritores como Jorge Amado, a amizade entre poetas como Manuel Bandeira e artistas como Pixinguinha: a aproximação entre a cultura erudita e a popular, entre a cultura acadêmica e a cultura do morro, em cujo ambiente veio a nascer a própria Bossa Nova.

Os dois filmes, Orfeu negro e Orfeu, apesar de serem baseados na mesma peça, recuperam o mito de maneira bastante diferente.

Na peça, "O morro é Orfeu". Existe identidade entre o cantor e o lugar onde vive. O espelhamento entre o estado de espírito do músico e o do morro continua no filme de Camus: quando Orfeu está feliz, a favela ri com ele, quando este perde Eurídice, a favela transforma-se. Como na peça, novamente encontramos a celebração do amor, mas, enquanto nela temos a promoção do diálogo entre a cultura erudita e a popular, ladeado pelo confronto social entre o morro e a cidade, no filme de Camus, sublinha-se a cultura do morro, cujo confronto com a cidade volta-se para o embate entre o antigo e o moderno. A música e dança singulares promovidas no morro pelo novo Orfeu aparecem aos olhos de Camus como atualização de uma beleza ancestral que revive, embora ameaçada pela modernidade que chega à cidade.

Diferentemente dos outros dois Orfeus, o de Carlos Diegues faz parte do mercado; é um famoso cantor, que continua, por opção, a viver no morro, mas com celular, computador etc. O morro também não é mais o mesmo, e todo o tom idealista, que já aparecia na peça de Vinícius de Moraes e que vigorava no filme de Camus, aproxima-se ao caráter de documentário. A celebração do amor cede lugar aos vários episódios sobre o tráfico de drogas, violência, miséria etc. Os 
"monstros" do filme, como aqueles do poema "Legado", também não são cativados por Orfeu. Mesmo assim, o valor artístico, como meio de transformação da dor - enxergando ou fazendo enxergar a existência dela -, tanto dos poemas de Drummond, quanto da peça de Vinícius e do filme de Marcel Camus também pertence ao Orfeu da década de 90 . As quatro obras, enfim, promovem, cada uma a seu modo, o desejo ainda atual por um novo canto de Orfeu, que promova as mudanças necessárias.

Se, por um lado, Orfeu é a referência comum e essas obras o atualizam em um mesmo período pelo qual passa o Brasil (com exceção de Orfeu, de 1999), por outro, os recortes do mito e, em conseqüência, as interpretações que partem daí são bem diferentes entre si. As diferenças são motivadas, principalmente, porque vêm de um sentimento poético, singular, em relação ao Brasil e ao lugar do poeta/poesia/canto; são expressões críticas de alguma forma apaixonadas (no sentido passivo do termo) que trazem à tona muito de nós não só enquanto habitantes de um país de terceiro mundo, em desenvolvimento ou algo semelhante, mas como habitantes ainda motivados pela idéia do poder criativo do canto|poesia sobre a realidade mais do que real em que vivemos, neste mundo. 


\section{CAPÍTULO I}

\section{O MITO DE ORFEU}

\section{1- A recorrência aos mitos}

A impressionante semelhança entre mitos dos mais diferentes povos indica uma porta singular de reconhecimento de nós mesmos, enquanto passíveis que somos de experiências humanas comuns. O reconhecimento pela alteridade, provocado pelos mitos, assemelha-se àquele provocado pela criação poética.

Joseph Campbell associa mito e força metafórica. Para ele:

A vida de uma mitologia brota e depende do vigor metafórico de seus símbolos. Estes transmitem mais do que apenas um conceito intelectual, pois seu caráter interior é tal que proporcionam um sentido de efetiva participação numa realização de transcendência. O símbolo, energizado pela metáfora, comunica não simplesmente uma idéia do infinito, mas uma certa realização. $^{7}$

As mitologias são metafóricas. Não são relatos de fatos históricos. Como as metáforas, os mitos carregam significados, realizam-se no ato mesmo em que são vivenciados, seja pela leitura, representação ou pelos diferentes rituais. Os mitos são derivados da contínua e enigmática relação entre o homem e o mundo em que este vive.

Quer concebamos a mitologia em termos da afirmação do mundo como ele é, da negação do mundo como ele é ou da restauração do mundo ao que deve ser, a primeira função da mitologia é despertar na mente um sentimento de assombro [...].

Julgaria isso como a função essencialmente religiosa da mitologia, ou seja, a função mística, a qual representa a descoberta e reconhecimento da dimensão do mistério do ser.

\footnotetext{
${ }^{7}$ Campbell, Joseph. Isto és tu: redimensionando a metáfora religiosa. (Trad.Edson Bini) São Paulo: Landy, 2002, p. 35.
} 
A segunda função [...] é interpretativa, apresentar uma imagem consistente da ordem do universo. Por volta de 3200 a.C., surgiu o conceito de ordem do universo, juntamente com a idéia de que a sociedade, homens e mulheres participam desta ordem cósmica, por ser ela realmente a ordem básica da vida do todo [...].

A terceira função [...] é dar validade e respaldo a uma ordem moral específica, da qual surgiu essa mitologia [...];

A quarta função é conduzir o individuo através de vários estágios e crises da vida, isto é, ajudar as pessoas a compreender o desdobramento da vida com integridade. Essa integridade supõe que os indivíduos experimentarão eventos significativos a partir do nascimento, passando pelo meio da existência até a morte em harmonia, primeiramente com eles mesmos, em segundo lugar com sua cultura, em terceiro lugar com o universo e, finalmente com aquele misterium tremendum que transcende a eles próprios e a todas as coisas. ${ }^{8}$

É interessante observar que na seqüência das funções do mito, a primeira e a última relacionam os mitos ao auto-conhecimento, seja pela via mística, seja pela didática. As metáforas "desempenham sua função de falar" aos "níveis profundos do ser humano", ou seja, aos "arquétipos do inconsciente coletivo", definidos por Jung. Com o correr do tempo essas figuras de linguagem podem ir perdendo a capacidade de serem absorvidas, mas os artistas, "de acordo com suas disciplinas e artes", fazem-nas emergir "do contexto contemporâneo da experiência".

Os artistas partilham da vocação [...] de fundir as novas imagens da mitologia, ou seja, eles produzem as metáforas contemporâneas que nos permitem compreender a natureza transcendente, infinita e abundante do ser como ele é. Suas metáforas constituem os elementos essenciais do símbolo que tornam manifesto o esplendor do mundo como este é, isto em lugar de argumentar como este deveria ser de um modo ou de outro. Elas o revelam como ele é.

[...] As linguagens metafóricas tanto da mitologia quanto da metafísica não denotam mundos ou deuses reais, e sim conotam níveis e entidades no interior da pessoa tocada por elas. As metáforas apenas aparentam descrever o mundo exterior do tempo e do espaço. Seu universo real é o domínio espiritual da vida interior. ${ }^{9}$

\footnotetext{
${ }^{8}$ Idem, p. 30.

${ }^{9}$ Idem, p. 46.
} 
Na trilha de Freud quanto à relação entre as instâncias extra conscientes e a função simbólica dos temas míticos, mas com um método bastante diferente do elaborado pelo pai da psicanálise, encontra-se o trabalho de Paul Diel (Viena, 1893 - Paris, 1972), ferramenta esclarecedora nas análises realizadas neste trabalho.

Segundo Paul Diel a "imaginação afetiva", função predominante da psique primitiva, incitou os homens primitivos a verem, nos fenômenos cósmicos e metereológicos, forças intencionais benévolas ou hostis a eles. A alternância de luz e escuridão, da lua e do sol (vistos como divindades) significava uma luta sem descanso entre estas forças. Com o desenvolvimento das culturas agrárias e a dependência ainda maior do homem em relação à regularidade desses fenômenos, sua "imaginação", além de "afetiva e divagante", passa a ser "expressiva e simbólica", "ela se torna capaz de criar símbolos, ou seja, imagens com significação precisa tendo por finalidade expressar o destino do homem"10. As divindades solares e lunares multiplicam-se. Zeus, por exemplo, não é visto neste momento apenas alegoricamente, como o trovão, mas se torna o símbolo do espírito, e o "trovão lançado simboliza o esclarecimento do espírito humano, enviado pela divindade salvadora, fonte de toda a verdade”. Para o psicólogo:

A significação simbólica que substitui o sentido alegórico é de ordem psicológica uma vez que ela subentende uma atividade intencional das divindades antropomorfizadas. As intenções simbólicas das divindades são unicamente a projeção das intenções reais do homem, cria-se uma corrente de obrigações entre o homem real e o símbolo "divindade". O homem encontra-se, por um retorno de sua própria projeção idealizante, como "convidado" a participar da luta travada pelas divindades benévolas, para o bem estar do próprio homem. Da mesma maneira que as antigas imaginações em relação à "luta" dos astros, as divindades antropomorfizadas só existem em relação ao homem e às suas necessidades. Mas essas necessidades, por estarem de acordo com as intenções ideais, cujo símbolo é a divindade, não concernem mais às utilidades exteriores da vida. Elas concernem cada vez mais à satisfação essencial, à orientação sensata da vida humana: a disciplina na atividade e harmonia dos desejos. ${ }^{11}$ Essa satisfação essencial, a alegria, dom último

\footnotetext{
${ }^{10}$ Esta relação entre a sociedade e a criação simbólica dos mitos ("ordem do universo") coincide com a segunda e terceira funções dos mitos definida por Joseph Campbell, transcritas acima.

${ }_{11}$ A questão moral subentendida nesta descrição identifica-se à terceira função do mito definida também por Joseph Campbell.
} 
da divindade, se realiza através da atividade, e mesmo através da atividade utilitária; mas ela é determinada pelas intenções, pelos desejos mais secretos, dos quais a divindade torna-se o juiz simbólico: o distribuidor simbólico da recompensa ou do castigo. A atividade essencial do homem, o combate heróico, a purificação das intenções, são, simbolicamente falando, impostas ao homem pela divindade: a realização, a purificação dos motivos, causa das ações justas, são imaginadas como recompensas da divindade. ${ }^{12}$

Os monstros, ou seja, os símbolos contrários às forças do bem, relacionados às divindades lunares, são tomados ainda como projeção daquelas intenções secretas do homem. Este mecanismo subconsciente do homem atua como uma espécie de "observação íntima" dele, capaz "senão de compreender, mas ao menos pressentir os motivos que sustentam suas ações sensatas e insensatas" em relação aos outros. A metafísica do homem provirá da contemplação, enquanto o juízo moral de sua atitude provirá dessas forças simbólicas.

Assim a figuração mítica, que em sua origem falava apenas dos astros e suas evoluções imaginadas como uma luta entre divindades, acaba por exprimir os conflitos reais e intrapsíquicos humanos. $^{13}$

Para Paul Diel, este mecanismo simbólico é comum aos homens ainda hoje.

Existe uma espécie de observação íntima, tão pré-consciente como aquela dos mitos, mas que é habitualmente renegada, sinal de que é carregada de vergonha. Toda a simbolização do mito, segundo seu sentido escondido, não é outra senão a análise desta vergonha reprimida e do valor da confissão sublimadora. ${ }^{14}$

\footnotetext{
${ }^{12}$ Diel, Paul. Le symbolisme dans la mithologie grecque. Paris: Petite Bibliothèque Payot, p. 14.

${ }^{13}$ Idem, p. 15.

14 "[...] Esta observação íntima não é em si vergonhosa; ela é um fenômeno biologicamente adaptativo, e, como tal, é elementar e automática como o instinto. Ela substitui a segurança do instinto animal, porque o homem não poderia subsistir, se ele não perscrutasse sem cessar a intenção de todas as suas atividades, seja para controlar as suas próprias ações, seja para projetar na psique de outro os conhecimentos assim adquiridos em relação aos motivos humanos, a fim de interpretar, com sua ajuda, as intenções de seus semelhantes e de encontrar assim um meio de se impor ou de se defender. Podemos dizer que esta introspecção obscura de seus próprios motivos e a introspecção projetiva, a interpretação das ações do outro, ocupam a maior parte da vida
} 
Os motivos das ações humanas são elaborados nos "abismos da subjetividade", nas camadas mais profundas da psique. A visão mítica soube efetuar sobre o plano "surconsciente" e metafórico, a objetivação desses motivos. Conseguiu realizar, metaforicamente, o que a psicologia, segundo Paulo Diel, deveria realizar ${ }^{15}$, como, aparentemente, a criação artística realiza.

humana; elas são a preocupação mais constante de cada homem e a razão mais secreta de sua maneira de ser e de agir.

A introspecção é freqüentemente mórbida, precisamente porque ela é uma característica automática e incontrolada, produzida ordinariamente debaixo da soleira do consciente; ela ignora a lucidez e a objetividade que caracterizam o pensamento consciente; ela é supercarregada de afetividade ofuscante e subjetiva. [...] / para se orientar na vida, o homem deve evoluir em relação à lucidez sobre suas intenções secretas. Mas a dificuldade desta progressão evolutiva faz com que cada homem dentro de seu foro íntimo se refugie na afetividade que permite justificar imaginariamente as intenções insustentáveis e de falsear assim os motivos. A natureza biológica e adaptativa de introspecção-interpretação junta-se assim um caráter mentiroso e deformador que se torna causa da vergonha secreta, por sua vez, suscetível de ser reprimida ou sublimada. A espiritualização não é nada além do que o testemunho da mentira, e ao mesmo tempo, sua dissolução. A repressão é de longe a reação mais freqüente, porque o amor próprio deseja que cada homem esconda seus verdadeiros motivos freqüentemente inconfessáveis e que ele se vanglorie dos motivos plenos de uma sublimação falsa.

As conseqüências desta constante preocupação extra-consciente são da mais alta importância tanto para a vida humana em geral como para formação e, portanto, para a interpretação desta imagem da vida que são os mitos.

Se os motivos são falsos, as ações também o são, e toda a vida humana sofre. É deste sofrimento e da necessidade de superá-lo que falam os mitos. O único meio seria remediar a interpretação errônea dos motivos. Ora, a própria natureza previu este paliativo. Ao amor-próprio que reprime afetivamente os verdadeiros motivos, corresponde uma emoção que se opõe à mentira vaidosa em relação a si mesma, erro vital, falta essencial do homem. Esse ressentimento culpado [grifo meu] adverte sobre a ruptura da integralidade dos motivos e aplica-se às ações deficientes que provêm dos motivos falsos. Sendo pressentimento de um erro vital, a culpabilidade contém necessariamente a previsão obscura de uma direção sensata da vida ela é o germe de uma orientação em direção à faculdade de perceber intuitivamente a vida [vers le sens de la vie] [grifo meu]. Este sentido não é nada além do que o contrário perfeito da angústia culpável que corresponde à ruptura da integralidade intrapsíquica: a alegria que corresponde à harmonização dos motivos e das ações. A angústia culpável é então um tormento que adverte sobre uma perda da alegria, um remorso que exige seu próprio corretivo. $O$ conjunto desses sentimentos que oscilam entre angústia e alegria constituem uma instância biologicamente adaptativa, uma instância evolutiva ativante e preventiva em relação ao funcionamento sensato e insensato do psiquismo, uma instância pré-consciente, mais que consciente, 'surconsciente': a consciência. Longe de ser o resultado de uma prescrição de ordem sobrenatural, a instância surconsciente (a consciência) é o centro visionário de onde emana a imagem mítica do sentido [faculdade de conhecer intuitivamente] da vida: o símbolo "divindade" (figuração do ideal de harmonia e felicidade). A partir deste símbolo central são formados todos os outros símbolos que concernem ao combate heróico, combate destinado a prevalecer sobre esse engano [erreur] vital que é a falsa introspecção - interpretação e seu incessante cálculo de justificação mentirosa.”. Op. cit., p.17.

${ }^{15}$ Para Paul Diel: "Os mitos, assim compreendidos, colocam a psicologia diante de seu problema mais essencial: no lugar de recuar diante deste abismo da subjetividade que são as camadas profundas da psique onde se elaboram os motivos, ela deve sobre o plano consciente, refazer o mesmo trabalho de objetivação que a visão mítica soube efetuar sobre o plano surconsciente e metafórico/figurado. Recuar diante deste esforço de elucidação seria renunciar para sempre compreender a imagem da vida, os mitos e a própria vida. Idem. 
A idéia de que os mitos são metáforas do comportamento humano, de que significam muito mais que simples narrativas de conflitos entre deuses ou entre estes e os homens, volta e meia ganha corpo. Mesmo com o avanço da ciência e tecnologia, com suas explicações racionais dos fenômenos, este reflexo do mundo arcaico movimenta nossa cultura. $O$ interesse por essas narrativas milenares evidencia-se ao longo de nossa história, tanto pelos trabalhos de historiadores, arqueólogos e filósofos, como de artistas de todas as áreas: pintores, escultores, músicos, dramaturgos e poetas. Suas contínuas e diversas retomadas de Orfeu, Édipo, Medéia, Ícaro, Narciso, Eco etc. vão, a cada época, confirmando os mitos como arcabouço significativo da experiência humana de todos os tempos, trazendo consigo algo específico de cada época.

Os mitos gregos pertencem à época heróica, ou época de ouro na qual "a validade dos valores reside somente nos indivíduos que, mercê da sua vontade particular e da grandeza e atuação extraordinárias de seu caráter, se colocam à frente da realidade em que vivem"16. não há mediação entre o homem e as leis, instituições, ética, moral: homem e mundo formam uma unidade.

É difícil, principalmente em nossa época, compreender esta unidade - a chamada aretê grega. O exemplo exposto por Anatol Rosenfeld, quando diferencia "punição legal", própria do mundo das leis, mediado, e a "vingança", correspondente ao mundo heróico, pode nos ajudar:

[a punição legal] é imposta em nome do direito codificado e se exerce através dos órgãos do poder público, representados por numerosos indivíduos que são perfeitamente acidentais e substituíveis. Esta, a vingança, pode ser igualmente justa; mas ela decorre daqueles que se encarregam do ocorrido e que se vingam à base do direito que fala de dentro deles. $O$ vingador não é acidental, nem substituível (ele age em causa própria).

Desta integração derivaria o caráter "profundamente dramático" dos mitos, que, por sua vez, são consultados como oráculos pelo desejo de compreensão das "condições e experiências supra históricas do ser humano, tais como o amor,

\footnotetext{
${ }^{16}$ Rosenfeld, Anatol. Mito e o herói no moderno teatro brasileiro. $2^{\mathrm{a}}$ ed. São Paulo: Perspectiva. $\mathrm{p}$. 30.
} 
a morte, opções básicas em favor do bem e do mal, do conformismo ou inconformismo, da liberdade ou da escravidão". Experiências que, de alguma forma, apartam-se das ideologias.

Graças a este caráter, segundo Anatol Rosenfeld, retomando por sua vez Hegel, os artistas aspirariam a:

"reconstruir" o mito, muitas vezes em termos nacionais e autóctones e isso principalmente a partir dos movimentos românticos do passado, a fim de assim reconquistarem a unidade perdida e atingirem o impacto estético desejado. Boa parte da literatura e do teatro modernos procura recuperar a visão mítica ou pelo menos se esforça por usá-la. No teatro abundam as tentativas de empregar o mito grego, referindo-se analogamente a situações atuais. Pense-se, por exemplo, em Les Mouches (Sartre), peça que alude à Resistência. [...] pense-se em certas obras de Strindberg, Wedeking, O’Neill, Wilder, Lorca.

$\mathrm{Na}$ literatura narrativa o uso do mito e a tendência mitizante se fazem notar com insistência ainda maior. Basta mencionar os nomes de Hesse, Faulkner, Kafka, Thomas Mann e Joyce para ter uma idéia da intensidade com que se manifesta o desejo de recuperar a grande unidade sintética e a plasticidade sensível da visão mítica num mundo em que a fragmentação e a análise tendem a dificultar o labor artístico [...]. ${ }^{17}$ [grifo meu].

No mundo atual das burocracias, da indústria cultural, das leis do mercado, ou seja, no mundo demasiado complexo e cujas mediações crescem a cada dia e em progressão geométrica (para não dizer internáutica), as dificuldades de o artista "captar em termos sensíveis (particulares, singulares) a idéia geral [...]para render-se à plasticidade concreta exigida pela arte" parecem ser ainda maiores do que as da época em que Hegel já previa o fim da arte "considerando-a incapaz de com seus recursos, representar o mundo moderno, prosaico". Por outro lado, conforme Anatol, Hegel reconhece que:

[...] [apesar dos obstáculos] dificilmente podemos descartar a necessidade e 0 interesse pela totalidade individual e pela autonomia viva do herói [mítico], ainda menos quando se trata da arte em que é essencial a manifestação do substancial, da idéia geral, através da concreção individual, sensível $[\ldots]^{18}$

\footnotetext{
${ }_{18}^{17}$ Idem, p. 36-7.

${ }^{18}$ Idem, p. 30.
} 
2 - O mito de orfeu

Toda uma produção artística sobre Orfeu tem início na Antigüidade grecolatina com os poemas de Ovídio, de Virgílio, o teatro de Eurípides e mesmo a comédia derrisória de Aristófanes em torno da teogonia difundida pelo músico. $O$ interesse por ele continua no início do canto operístico, na romântica Itália do séc.XIX; nas esculturas de Rodin, do séc. XX na França - de cuja beleza derivam os versos de Rilke; no teatro, ensaios e filmes de Jean Cocteau na década de 60 etc.

O canto de Orfeu atinge a ferocidade dos animais, a natureza e o próprio destino trágico ao qual o músico é submetido. O resultado é sempre transformador. Seja como aquele que encanta ou amante que sofre, o motor de seu canto é o desejo de paz ou consolo; é o querer - este impulso de vida, causa da primeira inspiração -, força constante a nortear esta espécie de arquétipo dos cantores e poetas de sempre.

São vários os motivos $^{19}$ do tema de Orfeu: o diálogo com animais e a natureza onde vivem; a procura pela origem dos homens e a divulgação disso; a busca do Velocino de ouro; a procura pela origem dos homens e a divulgação disso ; a busca do amor perdido ; a culpa pela separação definitiva deste mesmo amor; a experiência da descida ao Inferno, que gera um conhecimento singular, tudo isso movido pelo canto, expressão pessoal transformadora, que a tudo toca e cuja ação ritual abre caminhos para a espiritualidade.

O Orfismo, iniciado por ele após sua descida ao Inferno, proclama e promove o encontro eterno entre homens e deuses, inimaginável pela religião oficial grega ${ }^{20}$.

\footnotetext{
19 Tomo o termo com a acepção dada por Raymond Trousson em Thèmes et mythes. Cf.: Bruxelles: Éditions de l'Université de Bruxelles, 1981. De maneira simplificada, os motivos podem ser tomados como as características gerais personificadas por um personagem. $\mathrm{O}$ motivo da sedução, por exemplo, "encarna-se, individualiza-se e concretiza-se" na personagem de Dom Juan.

${ }_{20}$ Estado marginal, semelhante ao destinado à Poesia, no Banquete, de Platão.
} 
Embora dotado de poderes sobre-humanos, Orfeu não é um Deus, não possui a diferença definitiva entre as duas categorias. Orfeu é mortal ${ }^{21}$. Mas, acima dos homens, pelo seu dom musical, mesmo que abaixo dos Deuses, ele aproxima as duas categorias, pelo que é, músico/ cantor, e pelo que faz. Orfeu é mortal, mas seu canto, ressoando o sofrimento da busca fracassada, enfrenta e resiste à morte. Abatido pelo sentimento definitivo de perda, a morte da amada, ele resiste pela transfiguração. Ironicamente, passando pelo sentimento da morte, pela descida malograda ao Inferno, atravessando a dor, ele aproxima-se dos deuses. Seu canto lamento é em si mesmo inspiração daquele que ficou só, mas vivo; inspiração que se perpetua no chamado insistente; apelo contínuo mesmo depois da morte de si mesmo. O herói (assim como a Arte, ou graças a ela) vence a morte.

\section{"Orphée au nom fameaux" 22}

Embora o mito de Orfeu seja bastante conhecido, proponho uma leitura mais genérica sobre ele, baseada em estudos da Mitologia, Arqueologia e Psicologia como um caminho para a interpretação das novas metáforas construídas pelo "Canto órfico", "Legado", Orfeu da Conceição e suas adaptações cinematográficas.

\footnotetext{
21 "Orfeu não era considerado como um deus, mas como um herói, como alguém a quem se pode atribuir algum parentesco com os deuses, que graças a isso possui certos dons sobrenaturais, mas que, no entanto, deve viver e morrer como um mortal comum. A tumba de seres como este era normalmente venerada (encontrava-se mais de uma) e o culto do herói morto começava ali, culto em geral bem distinto daqueles de um deus, muito próximo do culto a um santo. Orfeu não foi jamais, ou muito raramente, adorado como um deus. Seu papel era o de um profeta e de um grande sacerdote [...]." Guthrie, W.K.C. Orfée et la religion grecque. Étude sur la pensée orfhique. Paris : Payot, 1956.

${ }^{22} \mathrm{O}$ epíteto deixado por lbykos, poeta grego que, como Orfeu, viveu no séc. VI a.C., chama a atenção de vários pesquisadores do mito de Orfeu. Tanto o livro de Guthrie [op.cit] como o de Simonne Jacquemard e Jacques Brosse [Orphée ou l' initiation mystique, Paris : Bayard ditions, 1998] são iniciados por esta citação. Reynaldo Sorel também faz referência a esta consideração sobre Orfeu. [op. cit., p. 9].Como sublinha Guthrie, se por si só a frase não confirma a existência física do músico trácio, deixa clara a sua importância vindoura.
} 
Sem fugir do objetivo deste capítulo, de trazer informações sobre Orfeu, penso que vale destacar o particular envolvimento daqueles que pesquisaram este mito. Tendo por base praticamente um mesmo material, as escolhas das citações de trechos de manuscritos, dos adjetivos relativos a Orfeu e das descrições de imagens, das alusões ao que Platão e Aristóteles teriam considerado acerca de Orfeu e da religião fundada por ele expressam ora o que parece ser uma crença contida na existência física do músico encantador de homens e feras, ora uma certeza que parece transcender a própria pesquisa, numa fusão mesma entre o desejo do pesquisador e o que ele encontra em meio às lâminas de ouro, onde estão inscritos poemas órficos e os vasos e pedras preciosas com as cenas que se repetem propagando a trajetória do mito. Assim, o esperado discurso científicoobjetivo traz com ele o pulsar da subjetividade que determina as diferenças.

W.K.C. Guthrie é um bom exemplo do primeiro caso. Em Orphée et la religion grecque, de 1957, obra extensa e indicada em muitos outros trabalhos sobre Orfeu, são numerosas as vezes em que o pesquisador, com certo entusiasmo, supõe a existência de Orfeu "como homem verdadeiro [ ...] que, há tempos atrás, viveu e morreu como nós" e logo em seguida problematiza a dificuldade de se fazer afirmações mais definitivas: "à medida que tentamos situá-la no curso dos séculos, a figura de Orfeu esfumaça-se cada vez mais, ela escapa-nos ". Por outro lado, a consciência científica de Guthrie não evita que percebamos em seu texto, quando se refere às influências sobre Orfeu, alguma resistência ao "selvagem" Dionísio e grande admiração por Apolo. Gutrhie, inclusive, acredita na natureza puramente apolínea de Orfeu; para ele, não há nada de dionisíaco em Orfeu, salvo a religião e mesmo ela não seria a religião comum de Dionísio, mas uma religião particular que comporta seus mistérios, tudo indicando que o músico entrevia nela a possibilidade de modelá-la sobre outras bases.

No segundo caso, certamente estão Simone Jacquemard e Jacques Brosse (Simone, antes de iniciar sua abrangente pesquisa sobre Orfeu, já era, 
também ela, poeta). Sempre de maneira entusiasta, os pesquisadores apontam, como Guthrie, as qualidades de Apolo, mas diferente dele, marcam a importância de Dionísio:

A poesia de Orfeu é em primeiro lugar o canto de Apolo - expressão, aparência, música e palavra - mas seu conteúdo, através da paixão de Dionísio, exprime o mistério de Dionísio. [... $]^{23}$

Os deuses Apolo e Dionísio de características tão diferentes estão estreitamente relacionados a Orfeu. Isso talvez explique sua complexidade e a atração que seu canto provoca tanto de plantas, animais etc. como de simpatizantes "apolíneos" e "dionisíacos".

Apolo, como sabemos, é o Deus da harmonia; da beleza escultural, "o mais grego de todos os deuses"; divindade essencialmente benéfica - embora o descrevam também como impiedoso -; promotor da relação direta entre os homens e os deuses ajudando os primeiros a saber da vontade dos outros e a maneira de se reconciliar com eles; guerreiro, o primeiro a ensinar a Medicina aos homens; músico e dono de um arco de prata com flechas de ouro que nunca erram o alvo. Apolo é, sobretudo, o deus da luz, aquele no qual nenhuma sombra habita, o deus da Verdade. ${ }^{24}$

Filho de Zeus e Leta, ele vai, ainda pequeno, ao encontro de Pitão, a serpente que, perseguindo sua mãe, levou-a a se esconder na ilha de Delfos, para que pudesse dar a luz a ele e sua irmã, Ártemis. Depois de matar o monstro com sua flecha certeira, Apolo enterra o monstro e sobre ele ergue o sagrado oráculo de Delfos, "lugar onde são revelados aos homens os julgamentos de Zeus". Após vencer a batalha, o deus compõe uma música e letra narrando o "contraste entre a difícil batalha e a paz, o contraste entre a destruição e a criação, entre a morte e a

\footnotetext{
${ }^{23}$ Orphée ou l'initiation mystique. Paris : Bayard Éditions, 1998

${ }^{24}$ Cf.: Hamilton, Edith. La mitologie: sés dieux, sés héros, sés légendes. Belgique: Marabout, 1977, p. 32 ; Stephanides, Menelaos. (Trad. Ganymedes José). Rio de Janeiro: Ediouro/Tecnoprint Ltda, 1984, p. 13.
} 
vida [...] uma canção de grande beleza que a natureza ouviu em silêncio, enquanto se enchiam de lágrimas de felicidade, os olhos daqueles que viviam oprimidos" 25 .

Tanto Orfeu, como Apolo tocavam o mesmo instrumento. Pinturas e esculturas do séc. III ou IX a.C. chegam a apresentar Orfeu vestido com os trajes de Apolo, em cenas tipicamente órficas, em que os animais ao redor do músico trácio admiram seu canto. Alguns autores afirmam que Apolo, e não Eagre, o rei da Macedônia, seria o pai de Orfeu; para outros, a confusão vem do fato de Apolo ter sido o mestre de Orfeu, ensinando-o a tocar a lira. ${ }^{26}$

A versão drámatica de Ésquilo, sobre a morte de Orfeu, que é a mais antiga de que se tem registro, conta que, depois da descida ao Inferno, Orfeu era um adorador fervoroso de Apolo, o deus do sol $^{27}$. Era seu costume escalar o monte Pangée ao amanhecer para saudar a aparição do astro do dia. Por isso ele teria provocado a cólera de Dionísio, que estava convertendo a Trácia, antes domínio de Apolo, a seu próprio culto "selvagem". Dionísio envia contra Orfeu suas adeptas selvagens, as Mênades (ou bacantes), que o despedaçam, como tinham o costume de fazer com os animais ou no curso de suas orgias; Virgílio parece seguir Ésquilo descrevendo o assassinato como um ato de fúria báquica.

Dionísio é o filho do imortal Zeus, o maior entre os deuses, e de Semele, uma mortal. É o deus do vinho, e, como este, é visto ora como o melhor dos bens, aquecendo o coração dos homens, ora como o pior dos males. Dionísio nasce da coxa de Zeus. Semele, persuadida pela enciumada Hera, mulher e irmã de Zeus,

\footnotetext{
${ }^{25}$ Stephanides, Menelaos. Idem, p. 15.

26 "Uma estátua romana que data do fim da República, que foi encontrada sobre o Esquilin, [...] mostra [...] Orfeu com os mesmos trajes de Apolo: um homem jovem nu coroado de louros e tocando uma lira; a estátua poderia ser tomada por ser Apolo, se não fossem os pássaros em seu joelho e outros animais à maneira bem conhecida dos animais encantados pelo canto de Orfeu [...]. A tradição que dá Apolo como pai de Orfeu não era muito corrente na idade clássica, e Pindaro nos diz que Orfeu foi 'enviado por Apolo'. Ele é designado como companheiro de Apolo em uma inscrição em volta de um monumento da Trácia." Gutrhie, W.K.C., op. cit.

27 Jacquemard, Simone e Brosse, Jacques. Op. cit., p. 27.
} 
pede ao deus do Trovão que se mostre em sua forma natural. Este, não conseguindo persuadi-la e tendo jurado por Styx que atenderia a um pedido da amada, fosse ele qual fosse, transforma-se em um "esplendor fulminante". Semele é atingida mortalmente, mas Zeus ainda consegue retirar dela Dionísio e colocá-lo em sua coxa, a fim de finalizar a gestação de seu filho.

Já rapaz, Dionísio volta a sua terra natal, depois de longo périplo, acompanhado de um séqüito do qual participavam as jovens bacantes, passando pela Trácia (onde nascerá Orfeu), e por várias outras cidades, fugindo do ódio da madrasta e sempre vítima de perseguições de "personagens bem instalados em suas terras".

Depois de sair das profundezas marítimas, onde estava protegido por Tétis, e de realizar uma "espécie de iniciação clandestina", conquista a Ásia, com um "exército de fiéis, sobretudo de mulheres que, sem dispor de armas clássicas de guerreiro, combatem a golpes de tirso, isto é, grandes hastes vegetais pontudas, nas quais estão fixadas pinhas, e que têm poderes sobrenaturais ${ }^{28}$. Por todos os lugares onde passa, ensina aos homens a arte de cultivar a vinha e os mistérios de seu culto. Era recebido como um Deus. ${ }^{29}$

Dionísio ora é afugentado por ser estrangeiro, ora é reconhecido como um Deus.

Em Tebas, ele quer restaurar o contato entre os homens e os Deuses, na vida da cidade, indo de encontro ao que Perseu representava. Sob sua influência, as mulheres começaram a sair de seus lares, abandonar seus maridos, indo encontrar as bacantes na floresta. Lá entravam em perfeita integração com a natureza, felizes, chegavam mesmo a amamentar os animais no seio, como filhos; "bastava uma pancadinha com o tirso e do solo jorravam fontes de água pura, leite, vinho. A idade de ouro voltava"30. Mas ao sentir a violência guerreira contra elas, enviada por Penteu, "essas mulheres angelicais" transformaram-se em

\footnotetext{
${ }^{28}$ Vernant, Jean-Pierre. O universo, os deuses,os homens: mitos gregos contados por Jean-Pierre Vernand. São Paulo: Companhia das Letras

${ }^{29}$ Hamilton, Edith. Op. cit.: 65.

${ }^{30}$ Idem, p. 155
} 
"fúrias assassinas", eliminando os soldados. "Vitória da suavidade contra a violência, do campo selvagem contra a ordem cívica".

O culto a Dionísio é centrado em duas idéias bastante diferentes: a liberdade, o êxtase de alegria e a brutalidade selvagem. Dependendo da situação, este deus tanto podia ser amável como cruel. ${ }^{31}$

Sob o seu domínio, a coragem é estimulada e o temor banido - pelo menos por algum momento. Ele transporta seus adeptos, insufla neles a convicção de que são capazes de realizar o que antes achavam estar acima de suas forças. Toda essa facilidade feliz, toda essa confiança se dissipava, certamente, conforme estavam sóbrios ou bêbados, mas enquanto o efeito durava, tinham a sensação de possuir um poder maior do que eles mesmos. $O$ que experimentavam com Dionísio não parecia em nada com o que lhes inspiravam os outros deuses. Dionísio existia fora deles, mas também neles próprios. Esta sensação momentânea do poder que dava a embriaguez era somente um sinal que mostrava aos homens que eles possuíam dentro de si bem mais do que sabiam, "eles mesmos podiam se transformar em deuses".

Como Orfeu, Dionísio desce ao Inferno, mas diferentemente do músico, sai vitorioso: consegue levar sua mãe, não de volta para a terra, como queria Orfeu em relação a Eurídice, mas para o Olimpo, junto aos deuses. Como Orfeu, Dionísio é estraçalhado. Por ciúme, a mando de Apolo ou Hera, ou por iniciativa dos próprios Titãs, o deus do vinho é enganado e morto pelos monstros, que terminam por engoli-lo.

O destino trágico de Orfeu, despedaçado pelas bacantes, assemelha-se ao de Dionísio, estraçalhado pelos Titãs. O canto de Orfeu sobreviveria a sua própria morte. Dionísio é morto, desmembrado e engolido pelos irmãos enciumados, mas Zeus, seu pai, sabendo do fato, incinera os Titãs e das cinzas e do vapor

\footnotetext{
${ }^{31}$ Hamilton, Edith. Op. cit.: p. 68.
} 
produzido, (por causa disso ou graças a isso) nascem os homens, portadores em si mesmos do caráter divino e terreno. Novamente a vida vence a morte.

O Orfismo ${ }^{32}$, iniciado por Orfeu, é derivado dos mistérios de Eleuses - que louvavam inicialmente Perséfone e depois Dionísio e cujos fiéis acreditavam, a partir das experiências destes deuses, na imortalidade da alma e na vida após a morte. Perséfone volta para a terra, saindo do Inferno, a cada primavera; Dionísio, assim como as vinhas, morre com a chegada do frio, numa experiência trágica, mas volta depois à vida. Essa crença pressupunha a imortalidade da alma e a origem divina do homem baseada no mito de Dionísio desmembrado pelos Titãs:

Os órficos contestavam radicalmente [a religião oficial que pregava] a separação entre os homens e os deuses e sua conseqüência direta, ou seja, a identificação da alma humana defunta como sombra definitivamente presa no Hades, onde ela não é mais nada além de uma imagem, um simulacro da sombra que vive.

[...] A alma não pode morrer por causa de sua origem divina, mas ela é maculada por uma morte ancestral [de Dionísio]. Esta parcela imortal se encontra condenada a ser aprisionada [...] no corpo ("soma") como em um túmulo ("sema") enquanto ela não tiver pago o "resgate" exigido por Perséfone (mãe de Dionísio), em compensação do "antigo luto" da deusa. As condições do nascimento do homem valem a ele os ressentimentos da mãe de Dionísio: a dissiminação da imortalidade, enquanto almas humanas, relembram e dor de Perséfone; pior, esta dor é renovada, quando estes mesmos homens acreditam honrar os deuses repetindo através da prática oficial do sacrifício sangrento $o$ ato da morte de seu filho.[...]

Os homens podem escapar dos ressentimentos que the valem sua natureza "titânica" conformando-se às regras ascéticas do "gênero de vida órfica" [...] destinados a apaziguar o sofrimento de Perséfone: abluções catárticas, proibição de ingestão de carne e de sacrifícios com efusão de sangue. A vida ascética é o preço do resgate. O orfismo exprime sob a forma mitopoética o imperativo para a alma se libertar do corpo ao término de vidas sucessivas e assim reencontrar o divino original. A salvação do homem que consistia precisamente no término das existências terrestres é o resultado da iniciação perfeita que interrompe o ciclo doloroso da metesomatose acionada pelo assassinato cometido pelos Titãs. A encarnação assemelha-se a uma morte e a morte pode constituir o começo de um vida feliz. Isto não é obtido automaticamente, mas ao fim de uma iniciação que, para os órficos é sinônimo de purificação cotidiana, de observância absoluta das regras restritas de abstinência [...], a "tudo o que teve vida", o que

\footnotetext{
${ }^{32}$ Nascido no mundo helênico no séc. VI a.C. Sorel, Reynal. Op. cit., p. 5.
} 
implica em uma dieta vegetariana[...] a piedade não pode ser a repetição da morte primordial, mas uma ascese. Quanto à alma impura, esquecida da dor original, ela é submetida a lei do "ciclo das existências",[...] um ciclo de renascenças infinito para os não iniciados. [...] O Orfismo apresenta, entre outras, a particularidade de não acompanhar com qualquer exaltação o pressentimento de uma vida eterna.

A mancha é supra-humana. O homem não tem a qualidade do "pecador original". Mas, sendo o mal hereditário, a existência (órfica) será uma vida de expiação. Qualquer pessoa que esteja atento a não reviver a dor de Perséfone será subtraído ao ciclo da geração e da corrupção para reencontrar o divino original, enquanto que os não iniciados, que confundem piedade com matança ritual, reencarnarão em condições grosseiras e mesmo animais. A religiosidade órfica tomava assim a forma de um profundo desapego, de um gênero de vida estranho aos ritos e sacrifícios próprios da religiosidade cívica. ${ }^{33}$

O Orfismo teria sido instaurado depois da descida de Orfeu ao Inferno à procura de Eurídice. ${ }^{34}$

\section{A esposa de Orfeu}

foi provavelmente uma ninfa da Trácia, ou uma Druade, conquistada pelo encanto da música de Orfeu. Ela morre por causa de uma mordida de uma serpente em que ela pisa; segundo o relato de Virgílio, escapando de Aristeu, que a perseguia. Orfeu desolado, após tentar, em vão, se consolar com sua lira, acaba por descer ao reino de Plutão passando pela entrada que, dizem, encontrava-se no abismo de Ténare. Chegando ao Inferno, Orfeu se põe a tocar e as sombras fecham-se ao redor dele como os pássaros que ao final do dia ou em tempos de tempestade se apressam loucamente em direção a uma árvore florida. As Eumênides e Cérbere ficaram dóceis [...] Orfeu obtém assim a graça de sair com Eurídice do mundo dos mortos. ${ }^{35}$

Uma passagem de Alceste sugere o sucesso de Orfeu, e Hermésianax também afirma isso. ${ }^{36}$

\footnotetext{
${ }^{33}$ Idem, p. 6-9.

34 "À exceção dos versos inscritos sobre as lâminas, a compreensão do movimento órfico repousa sobre os testemunhos de segunda mão que se atropelam sobre mais de um milênio de anos. Idem, p. 13." Idem.

${ }^{35}$ Op. cit., p. 42.

${ }^{36} \mathrm{O}$ poeta alexandrino Hermésianax fala de Agriope "olhos selvagens", "nome que bem convém a uma ninfa da Trácia ou de Dryade, regiões onde Orfeu teria vivido, e que teria sido
} 
Sobre o fracasso de Orfeu em recuperar Eurídice, segundo Guthrie, Platão informa que os deuses fizeram Orfeu voltar do Inferno de mãos vazias, não tendo mostrado a ele senão o fantasma de sua esposa, e não a sua mulher verdadeira,

porque ele era somente um pobre músico sem coragem que procurara entrar no Inferno vivo, no lugar de ter a força de morrer para encontrar de maneira normal a sua bem amada [como Alceste fizera] [...].

\section{Para Guthrie,}

A história de Orfeu olhando para trás, e condenado por causa disso a deixar Eurídice, pode muito bem ser um acréscimo que só foi adotado universalmente no período alexandrino, se é que não foi inventado mesmo pelos alexandrinos. Era em todo caso uma história bem feita para ser explorada pelo espírito romanesco e patético que eles foram os primeiros a introduzir na literatura, como foi abundantemente provado mais tarde[...]Uma variante diz que a interdição também seria sobre a fala [...]. No relato de Ovídio, Orfeu tenta retornar ao Inferno, mas desta vez encontra o caminho barrado por Charon ${ }^{37}$.

Já Reynal Sorel vê no texto de Platão apenas uma argúcia, uma sutileza que o filósofo "empresta" à Fedra para que ela torne mais eficaz o seu discurso a respeito das "ilusões sobre o amor"38.

Para Guthrie, o ponto mais importante é descida de Orfeu ao Inferno; a razão que o teria de início levado até lá seria secundária:

os segredos de Hades estavam em seu poder, ele poderia revelar a seus adeptos qual seria o destino de suas almas e como eles deveriam se conduzir para que o destino fosse o melhor possível. Orfeu mostrou ser capaz de sensibilizar as divindades infernais e podia se esperar que ele intercedesse ainda em favor dos seus discípulos, se eles levassem uma vida pura

verdadeiramente a esposa de Orfeu". O nome de Eurídice ("vasto império") aparece pela primeira vez em literatura em um canto fúnebre em honra a Bien (séc. V a.C.); aparece também sobre um ou dois vasos do sul da Itália, que nos mostram Orfeu e Eurídice no Inferno, em que o nome Eurídice aparece ao lado de Orfeu, mas a maior parte dos artistas, como Polygnote, ressalta Guthrie, "representa um Orfeu que parece à vontade em Hades, não tendo nenhuma necessidade do pretexto da procura conjugal para justificar sua presença". Somente nos poetas latinos como Virgílio e Ovídio encontramos o tema elaborado em um relato completo e detalhado.

${ }^{37}$ Op.cit.

${ }^{38}$ Op. cit., p. 28. 
recomendada por ele.

Reynaldo Sorel amplia a importância da experiência de Orfeu:

Orfeu vindo sozinho do domínio dos mortos renasce dentro da diferença (ele não é mais "o mesmo" que desceu ao Inferno) e do sofrimento. A ascensão (renascimento|reencarnação) é muito freqüentemente ocultada em proveito da descida (morte, ou seja, a alma colocada no cruzamento da vida feliz - às custas da memória - ou do retorno à vida terrestre, metensomatose provocada pelo esquecimento).

Esta nova vida é uma ferida, uma errância, uma solidão, uma dolorosa quebra. Mas Orfeu é mais "consciente" (iniciado) do irreparável que cometeu esquecendo a lei de Perséfone. Esta é a razão pela qual seu mito, perfeita ilustração da metensomatose, incita os homens a cultivar as virtudes da memória dos ritos a cumprir, do caminho a seguir (tanto sobre a terra como no Hades) e as palavras a serem ditas para dirigir-se à divindade original e libertar-se da roda dos nascimentos que faz voltar o sopro continuo da imortalidade da alma. [...] A cabeça de Orfeu decapitada continua a cantar. $\mathrm{E}$ cantar para o grego é submeter-se à memória. ${ }^{39}$

É graças ao poder mágico de seu canto, variável e freqüente, que Orfeu toma lugar entre os Argonautas, a fim de protegê-los do canto das sereias. Já no início da viagem, pedem a ele que acabe uma discussão; ao ouvirem seu canto, os adversários esquecem a cólera. Narra-se em Argonautiques orfiques como o navio Argo começou por resistir aos esforços dos heróis para colocá-lo na água, só se deixando mover depois do sinal feito por Jason para que Orfeu pegasse sua lira. Feita por volta de 560 a.C., há uma escultura de Orfeu em pé no navio Argo, tocando a lira ${ }^{40}$.

O papel de Orfeu na viagem era o de céleustes, o cantor que escandia o movimento dos remadores, mas sua música tinha muito mais poder. Orfeu acalmava o mar em fúria com suas melodias, e, segundo o relato órfico, ele

\footnotetext{
${ }^{39}$ Op. cit., p. 28.

${ }^{40}$ Sorel, Reynal. Op.cit. p. 9. "As referências sobre a expedição de Jason e dos Argonautas, da qual Orfeu participara, são abundantes a partir de Homero e de Hesíodo, no entanto, são todas elas "isoladas" e "pouco conclusivas". O primeiro esboço, mais elaborado e que menciona Orfeu como um dos viajantes foi feito por Pindaro; além disso há os poemas épicos de uma época posterior, os Argonautas, de Apollo de Rhodes (por volta de 240 A.C.), uma imitação de Valleríus Flaccus (por volta do ano 80 a.C.) e o poema anônimo, Orphée, escrito talvez bem depois do séc. IV d.C., que conta em primeira pessoa, as aventuras de Orfeu e de seus heróis. Mais algumas referências raras encontradas em prosadores e é tudo o que se tem como informações sobre o papel de Orfeu durante a viagem." [cf.: Idem, p. 38].
} 
conseguia encantar os Rochedos Errantes, enquanto o Argo passava entre eles. Com o efeito do mesmo poder, quando chegaram à Colchita, Orfeu fez o dragão que guardava o Velocino de ouro se acalmar.

Orfeu não era somente um músico, mas um guia da expedição por tudo o que sabia sobre religião. Antes da saída do Argo, ele oferece um sacrifício propiciatório; passando pela Samotrácia, persuade os Argonautas a se iniciarem nos mistérios que tinham tornado a ilha famosa; depois da morte acidental do rei Kyzikos, oferece um sacrifício; a fim de liberar os heróis da maldição a qual o rei de Colchita Ihes tinha carregado, submete-se aos ritos purificadores à Malée, e, finalmente, antes de retornar à Trácia, como último gesto, Orfeu fica só no sorvedouro do Ténare (que diziam ser uma das entradas do Inferno) para prestar sacrifícios às divindades do mundo subterrâneo. Em outros relatos sobre a expedição dos argonautas, ele também desempenha um papel preponderante. Durante a viagem, o músico relata a origem de todas as coisas, o nascimento do mundo e dos deuses.

\section{Segundo Diodore ${ }^{41}$}

Depois de ter estudado por longo tempo e se aprofundado no estudo sobre os mitos que se relacionavam à teogonia, [Orfeu] foi morar no Egito onde ampliou seus conhecimentos e tornou-se o maior conhecedor entre os gregos da teogonia, de poesia e de música.

São creditadas a Orfeu três versões acerca da teogonia ${ }^{42}$. Na mais antiga de que se tem registro, a origem do mundo é creditada a um ovo de pássaro. Esta versão é ridicularizada em uma peça de Aristófanes. As outras duas versões

\footnotetext{
${ }^{41}$ Idem.

42 As obras atribuídas a Orfeu distribuem-se em dois grandes grupos: uma teogonia, da qual se conhece três versões e muitos poemas sobre temas diversos relacionados a esta teogonia ou à vida e às atividades de Orfeu. "À época imperial, ao lado desta teogonia, que comportava três versões, um grande número de escritos de gênero e conteúdo diversos circulavam sob o nome de Orfeu. É muito difícil fazer o inventário destes textos. [...] [Há] os textos explicitamente atribuídos a Orfeu e citados por autores conhecidos [...] [que] podem ser repartidos em quatro grandes classes: aqueles relacionados à vida e a atividades de Orfeu, os hinos em louvor aos personagens evocados dentro das diferentes versões da teogonia, as obras relativas às questões naturais como a astronomia e a medicina e os textos destinados a anexar a figura de Orfeu a um movimento filosófico ou religioso. [Brisson, Luc. Posfácio. In: Orphée: poèmes magiques et cosmologiques. Collection Aux sources de la tradition. Paris : Les belles lettres, 1993.]
} 
guardam semelhança com a teogonia descrita por Hesíodo, mas, em uma delas, a conquista do Olimpo feita por Zeus não é definitiva. Depois dele, Dionísio dá prosseguimento a um processo cíclico de "dispersão e reunificação, que parece não conduzir jamais a um estado de estabilidade fechado e definitivo, já que o fim parece conduzir ao início". Além disso, essa teogonia incorpora também uma antropogonia, já descrita acima: o nascimento dos homens a partir do vapor e das cinzas produzidas pela incineração dos Titãs que haviam engolido Dionísio ${ }^{43}$, e a conseqüente constituição dupla do homem: divina e terrena.

Nos primeiros séculos da Era Cristã, os cristãos, com medo de serem perseguidos, fingiam adorar Orfeu, no lugar de Cristo. A imagem dos peixes é associada aos dois. A ambos é associada a imagem de retirar os homens das trevas, como os pescadores retiram os peixes do mar, entregando-lhes a luz. A idéia da ressurreição e da imortalidade da alma também são comuns a eles.

"A sabedoria antiga dos gregos está ligada à música. O maior músico e o mais sábio entre os deuses era Apolo, e entre os semi- deuses, Orfeu". ${ }^{4}$ Para os gregos da Antiguidade, Orfeu não é só uma espécie de encantador de serpentes de uma espécie superior que conhecia o poder da música, que fazia vibrar todos os seres ao som de sua melodia quer eles fossem animados ou inanimados. Ainda segundo Guthrie,

isso não causaria aos gregos o espanto que nos causa, pois eles tinham penetrado melhor os liames íntimos que unem a música ao cérebro humano, mas os gregos viam em Orfeu qualquer coisa a mais. [grifo meu] ${ }^{45}$

Depois da perda de Eurídice e do tempo de luto pelo qual passa Orfeu sobre os rios de Strymon, ele evita inteiramente a companhia de mulheres.

Sobre a causa de sua morte, há opiniões variadas. Pausanias apresenta,

\footnotetext{
${ }^{43}$ Brissac, Luc. Idem.

44 Tanto Reynaldo Sorel [Op. cit. p. 20],.como Simonne Jacquemard [Op. cit. p. 21] destacam essa citação sobre o poder de Orfeu dentro da cultura grega.

${ }^{45}$ Op. cit., p. 12.
} 
além de sua opinião, uma enumeração de todas as "coisas falsas" em que os gregos acreditam; ele fala de um possível suicídio depois da morte de Eurídice e da existência, na cidade de Dium, na Macedônia, da tumba de Orfeu, onde se lia um epitáfio que dizia ter sido ele vítima da fúria de Zeus.

Orfeu teria desagradado ao deus, por uma razão próxima àquela de Prometeu: "em seus mistérios ele ensinava aos homens muitas coisas que eles não conheciam antes". Strabon explica o drama por uma conspiração fomentada entre todos aqueles compatriotas de Orfeu que não aceitavam seus ensinamentos. ${ }^{46}$

A tradição mais clássica coloca-o como vítima das mulheres da Trácia e da Macedônia $^{47}$. A versão drámatica de Ésquilo aponta a cólera de Dionísio, já descrita acima. Virgílio parece seguir Ésquilo descrevendo o assassinato como um ato de fúria báquica, mas ele prefere dar uma outra razão à fúria dessas criaturas: o desprezo com o qual Orfeu passa a tratá-las após a morte de Eurídice. Canon menciona que Orfeu recusa iniciá-las aos mistérios e Pausanias diz que ele afasta delas os seus esposos. Phanoclès dá como razão o ciúme, a mesma razão apontada por Ovídio.

Canon faz o seguinte relato sobre a morte de Orfeu:

Eis como ele morreu: foi colocado em pedaços pela mulheres da Trácia e da Macedonia, porque não permitia a elas que tomassem parte das cerimônias religiosas, ou talvez por outras razões, como a de ele ter se tornado inimigo das mulheres, após a morte se sua esposa. Um certo dia, uma massa de trácias e de macedônias em armas se reuniram em Libéthra e entraram juntas em uma construção que era vasta e bem escolhida para que se pudessem desenvolver os ritos de iniciação. Quando os homens entraram para as suas cerimônias deixaram todas as armas à porta. As mulheres aproveitaram este momento e, plenas de raiva da afronta a que eram submetidas, agarraram as armas, mataram aqueles que tentavam impedi-las, estraçalharam Orfeu, membro por membro, e jogaram seus restos no mar. Nenhuma represália foi impingida às mulheres, e o país foi invadido pela peste. Procurando qualquer solução, os habitantes consultaram um oráculo, que thes disse que se encontrassem a cabeça de Orfeu e enterrassem-na seriam libertados dos seus males. Depois de muitas dificuldades, encontraram a cabeça, graças a um pescador, ao redor da embocadura do rio Mélès. A cabeça cantava ainda, ela não tinha de maneira nenhuma sofrido por

\footnotetext{
${ }^{46}$ Idem.

${ }^{47}$ Sorel, Reynal. Op. cit., p. 26.
} 
sua estada no mar e não tinha sucumbido também a nenhuma das mudanças que se impõe aos corpos sem vida. Mesmo depois de muitos dias decorridos, a cabeça parecia normal e resplandecente [...]. Eles pegaram-na. O lugar onde a deixaram foi, em seguida, o santuário do herói, mas mais tarde se elevou lá um templo, ou seja, o lugar foi honrado de sacrifícios e de todas as outras homenagens rendidas aos deuses. Nenhuma mulher devia jamais colocar os pés em seu interior." ${ }^{48}$

Morto na Trácia, Orfeu teria sido enterrado pelas musas, ou seja, sua mãe e suas irmãs no mesmo lugar de seu assassinato. Outra versão é a de ele ter sido transportado para perto do monte Olimpo.

Pausanias diz que a tumba se encontrava perto da cidade de Libéthra, no Olimpo. Um oráculo de Dionísio havia advertido aos habitantes de Libéthra que se eles permitissem que os ossos de Orfeu vissem o sol, a cidade seria castigada. Naturalmente o povo não o levou em consideração e um dia a tumba foi mexida e quebrada, em conseqüência, uma das torrentes do Olimpo cobriu a cidade. Mais tarde, os habitantes da cidade vizinha, Dion, recolheram os ossos de Orfeu e deram a eles uma nova sepultura. Segundo Pausanias, a tumba ainda podia ser vista em sua época. De acordo com a história local, a urna que ainda podia ser vista continha os restos de Orfeu. Mesmo conhecendo a versão de que Orfeu teria sido morto pelo raio de Zeus, Pausanias afirma que o que se contava naquela região era que ele teria sido assassinado por mulheres na região vizinha.

Outra lenda corrente na Antigüidade está registrada em Lycidas, de Milton: a cabeça e a lira de Orfeu foram jogadas no rio de Hèbre; flutuaram ao largo da costa da Ásia até a ilha de Lesbos; mesmo separada do corpo despedaçado, a cabeça continuava cantando. Os moradores da ilha enterraram-na como descreve o poema de Phanoclès, repetido por um escrivão que cita as obras de um historiador local. Lucien nos diz que o templo de Baco teria sido construído em cima do lugar onde estaria a cabeça de Orfeu. A lira, assegura a tradição, tinha sido colocada no templo de Apolo onde foi por longo tempo conservada.

Os registros mais antigos que concernem à morte de Orfeu são pinturas de vasos que representam o assassinato e que remontam ao século $\mathrm{V}$ a.C. Sobre estas decorações, Orfeu não aparece jamais colocado em pedaços (Robert,

\footnotetext{
${ }^{48}$ Guthrie, W.K.C., op.cit., p. 74.
} 
Heldensage, sugere que era talvez por razões artísticas, esclarece Guthrie), mas as Fúrias estão munidas de todo um arsenal de armas em via de realizar o grande crime. Às vezes há apenas uma atacante, às vezes muitas, algumas mulheres são armadas de lanças, outras de machados, outras de pedras, algumas parecem ter conseguido apressadamente instrumentos mais caseiros como uma foice ou mesmo uma brocha. Isso pode sugerir uma vingança feminina antes natural que suscitada pela ordem divina, segundo Guthrie. Ainda, para o pesquisador, "Virgílio combina as duas idéias com a liberdade de um grande poeta, mas Phanoclès, que se prende à primeira versão toma as espadas trazidas pelas mulheres como instrumentos de vingança". Os artistas que decoram os vasos mostram muitas vezes a cena do assassinado combinada com aquela onde Orfeu encanta os guerreiros trácios tocando a lira, o que, para Gutrhie, prova que as decorações confirmam a influência de Orfeu sobre os homens e sua indiferença frente aos sentimentos de suas mulheres, motivando o assassinato.

A arte antiga fornece muitas ilustrações interessantes sobre este mito. Um espelho etrusco, em bronze, provindo de um túmulo de Chiusi, designado pelo seu estilo como sendo do séc.IV a.C., mostra a cabeça de Orfeu que olha o céu, os lábios entreabertos, com a inscrição de seu nome invertido. Muitas pessoas o escutam em pé, enquanto um jovem homem sentado ao lado direito toma nota dos oráculos sobre tabletes. O desenho praticamente se repete no decô de um Kylix, a cabeça que profetiza, o jovem homem sentado tomando notas e agora, à direita Apolo, em atitude interpretada ora como amizade ora como o seu contrário. Para Guthrie, pode-se dizer que Apolo se dirige a Orfeu com desprezo frente a sua popularidade, "avançando" a mão em "um gesto de autoridade". Em outro vaso, vê-se a descoberta da lira de Orfeu por duas mulheres de Lesbos. Os oráculos produzidos sobre o destino da cabeça de Orfeu formam também o tema de numerosas gravuras em pedra preciosas.

Para Guthrie, entre todas as dúvidas que possam existir, Orfeu tem, inegavelmente, uma individualidade bastante nítida. Essa pelo menos é uma conclusão a que se pode chegar segundo o estudo do personagem complexo que toda a documentação antiga apresenta : 
Há momentos em que Orfeu parece estar a ponto de se confundir com Apolo, o Deus que tocava a lira; há outras ocasiões, pensando em sua morte, que poderíamos perguntar se ele não seria uma encarnação de Dionísio trácio. Mas não, ele aparece sempre diferente, jamais totalmente igual a estes deuses e sendo certamente alguma coisa a mais. A complexidade de seu personagem às vezes faz crer aos eruditos, sejam eles antigos ou modernos, que ele não é um única personalidade, mas duas. A primeira coisa a fazer então seria estudar a psicologia do personagem [...]Orfeu é antes de tudo um músico cuja arte tem um poder mágico. Ésquilo sabia que ele encantava a natureza inteira com seus cantos [...] Para os gregos a magia se aliava de perto à música, e para alguns entre eles o nome de Orfeu era sinônimo [...] de sortilégios e encantamentos. Durante ao menos um milhar de anos, Orfeu foi um nome que tinha uma virtude mágica [...] [era] um mago de um tipo especial de religião de mistérios, modificação dos mistérios de Dionísio. Seus ensinamentos estavam contidos em textos sagrados. Tanto é forte a crença em sua antigüidade que alguns supõem ter sido ele o inventor da escrita ao mesmo tempo em que atribuem a ele uma reputação única como poeta. Outros acreditam que seja tão antigo que não podem, por isso, admitir que ele tenha escrito seus próprios poemas [...].

A influência de Orfeu se exercia sempre em favor da civilização e das artes da paz. Seu caráter pessoal não é de maneira nenhuma aquele de um herói, no senso moderno deste termo; ele possui uma característica dominante que é a doçura que em certos momentos torna-se nobreza.

[...] É absolutamente desprovido de atributos guerreiros, diferente nisso do deus-arqueiro selvagem com quem ele se assemelha por outros motivos. A atmosfera calma que o envolve difere estranhamente também das atitudes habituais do deus selvagem das montanhas do qual ele adota a religião. A música, é verdade, pode também excitar tanto quanto acalmar, mas os cymbales e os tympanons das orgias da Trácia ou de Phrygie pareciam à primeira vista não ter nada em comum com os acordes melodiosos da lira de Orfeu. A virtude desta lira consistia em tocar os corações dos guerreiros e direcionar seus pensamentos para a paz, podia também domar as feras mais selvagens. Os homens como os animais apressavam-se em torno de Orfeu para ouvir seus cantos. Nas pinturas que decoram os vasos gregos e que representam as cenas deste tipo, as expressões dos que escutam não nos deixam nenhuma dúvida quanto ao efeito produzido pela música de Orfeu, e um autor posterior a ele faz o eco dos seus prodígios: "Pela música e seus cantos, Orfeu ganha os gregos, transforma o coração dos bárbaros e doma os animais selvagens" [...]. Ele ensina aos homens a agricultura e para lá dirige seu espírito envolvido pela paz e pela doçura. [...]. 49

${ }^{49}$ Idem p.51-2 


\section{CAPÍTULO II}

\section{QUE LEMBRANÇAS DAREI?}

Tanto o poema "Legado", de Claro enigma [1948], como "Canto órfico" [1951], de Fazendeiro do ar, pertencem, como distingue o crítico José Guilherme Merquior, ao "quarteto metafísico" da obra de Carlos Drummond de Andrade, escritos entre 1948 e $1959^{50}$. Os poemas dessa fase, de caráter filosófico e "interrogação existencial", não abandonam as questões sociais evidentes nas obras anteriores; pelo contrário, conseguem potencializar a qualidade do lírico enquanto expressão do social. "Legado" e "Canto órfico" são exemplos dessas reflexões sobre o fazer poético, em que a figura evocada de Orfeu deriva, justamente, da tensão considerada entre o poeta e o mundo.

\footnotetext{
${ }^{50}$ Merquior, José Guilherme. Verso universo em Drummond; trad. Marly Oliveira. Rio de Janeiro: José Olympio, Secretaria de Estado de Cultura, Ciência e tecnologia, 1975. [...] a primeira grande contribuição do verso drummondiano consistiu em apreender o sentido profundo da evolução social e cultural de seu país. A partir de sua própria situação de filho de fazendeiro emigrado para a grande cidade, justamente na época em que o Brasil começava sua metamorfose (ainda em curso) de subcontinente agrário em sociedade urbano-industrial, Drummond dirigiu o olhar do lirismo para o significado humano do estilo existencial moderno. Desde então, tornou sua escrita extraordinariamente atenta aos dois fenômenos de base desta mesma evolução histórica: o sistema patriarcal e a sociedade de massa. Sua abertura de espírito, sua sensibilidade à questão social, sua consciência da história impediram-no de superestimar as formas tradicionais de existência e dominação, mas, ao mesmo tempo, ele se serviu do "mundo de Itabira" - símbolo do universo patriarcal - para detectar, por contraste, os múltiplos rostos da alienação e da angústia do indivíduo moderno, esmagado por uma estrutura social cada vez menos à medida do homem[...]".
} 
Meu filme não é nada de diferente de um strip-tease ...gradualmente tirando a pele do meu corpo para revelar minha alma toda nua para uma audiência bastante ansiosa por esta verdade além da verdade que se tornará um dia o sinal de nossa época. Este é um legado de um poeta para a mocidade, na qual ele sempre encontrou apoio.

[Abertura de Testamento de Orfeu, de Jean Cocteau]

\section{"LEGADO"}

Que lembrança darei ao país que me deu tudo que lembro e sei, tudo quanto senti? Na noite do sem-fim, breve o tempo esqueceu minha incerta medalha, e a meu nome se ri.

E mereço esperar mais do que os outros, eu?

Tu não me enganas, mundo, e não te engano a ti.

Esses monstros atuais não os cativa Orfeu, a vagar, taciturno, entre o talvez e o se.

Não deixarei de mim nenhum canto radioso uma voz matinal palpitando na bruma e que arranque de alguém seu mais secreto espinho.

De tudo quanto foi meu passo caprichoso na vida, restará, pois o resto se esfuma, uma pedra que havia em meio do caminho. ${ }^{51}$

\footnotetext{
${ }^{51}$ Andrade, Carlos Drummond de. Reunião (10 livros de poesia). $3^{\text {a }}$.ed. Rio de Janeiro: Livraria
} José Olympio Editora, 1973, p. 165. 
"Legado", análise e interpretação.

O poema é iniciado por uma questão:

Que lembrança darei ao país que me deu

tudo que lembro e sei, tudo quanto senti?

O último verso poderia ser a resposta:

uma pedra que havia em meio do caminho.

Reduzido dessa forma, um certo tom jocoso sobressai no poema. O final, que remete ao verso talvez mais conhecido de Carlos Drummond de Andrade, e certamente o que causou maior polêmica entre os críticos, ri ironicamente da questão afetiva e preocupada do início, como se toda a expressão poética de Drummond pudesse ser resumida a esse único verso, e ainda mais, à negatividade, assim isolada e fortuita.

O poema, é claro, não se resume a esses três versos, o tom de Orfeu é outro; é preciso aproximarmo-nos mais.

Ao determinar o modo como "tudo" foi sentido ("tudo quanto senti") ${ }^{52}$, o poeta sublinha seu envolvimento mais intenso pelo que foi sentido. Considerando o tempo verbal dos três processos ("lembrar" e "saber", no presente, e "sentir", no passado), parece haver, nessa determinação, a consciência de alguma superioridade (em quantidade e/ou intensidade) do que foi sentido no passado, em relação ao lembrado e sabido, no presente, que, por sua vez, problematiza ainda mais a resposta procurada: "Que lembrança darei ao país que me deu[...]".

\footnotetext{
52 "Tudo que lembro e sel" e "tudo o quanto senti" são dádivas do país ao poeta. O pronome "tudo" relacionado aos três verbos aproxima os processos de lembrar, saber e sentir: Além de serem presentes do país ao poeta, representam a totalidade dessas capacidades, com um adendo: no segundo hemistíquio do verso, a troca do pronome relativo "que" ("tudo que lembro e sei") pela expressão determinante "o quanto" acrescenta a sentir a noção de intensidade.
} 
Aparentemente a lembrança a ser dada (ou retribuída) deve equivaler ao recebido, deve ser merecedora do que foi sentido, e do que, no presente, é lembrado e sabido. A resposta deve satisfazer o desejo de retribuição do que foi recebido do país, como também, talvez, vencer a dificuldade de transformar o que foi processo (sentir) em substantivo (lembrança). Trazer o passado para o presente. Enfim, transformar a experiência em versos ${ }^{53}$.

A negatividade vinda a seguir, fechando a primeira estrofe, não traz a resposta, pelo contrário, parece invalidar ou suspender a questão,:

Na noite do sem-fim, breve o tempo esqueceu

minha incerta medalha e a meu nome se ri.

"Breve, o tempo esqueceu"; o tempo "ri”. À dádiva do país, ("deu"), corresponde o esquecimento do tempo ("esqueceu"); ao sentimento do poeta ("senti"), o riso indiferente do tempo ("ri”). O poeta que projetava sua atitude pressupondo o devir ("Que lembrança dare ${ }^{54}$ [...]?") identifica com prontidão o descaso do tempo contemporâneo, onde se destacam a brevidade, o esquecimento e o riso. O tempo presente não rirá, ele já ri. O futuro deixa de existir para um tempo que só considera o presente.

A pressuposição do futuro move a ação especulativa do poeta, mas o tempo presente, a princípio, desvia esta atenção. Este tempo debochado, que ri e que esquece o passado, obstaculiza a pressuposição do futuro - motriz da imaginação poética. Opondo-se à conjunção entre poeta e país, evidencia-se a divergência entre o poeta e o tempo presente: o país dá ("tudo o que lembro e sei, tudo o que senti"), mas o tempo esquece ("minha incerta medalha, e a meu nome se ri”).

Depois de colocado o problema na primeira estrofe, a segunda estrofe desenvolve a questão:

\footnotetext{
${ }^{53}$ A repetição do verbo "dar", no final dos dois hemistíquios desse verso, acentua a idéia do desejo de reciprocidade do poeta em relação a país.

${ }^{54} \mathrm{O}$ uso do verbo "dar", no futuro, marca a distância da efetivação do processo ("darei"), quando comparada à expressão equivalente : "vou dar", que pressupõe ação imediata. O uso do tempo futuro parece assim precisar a preocupação com o devir e sublinhar o conflito vivido entre o poeta e o mundo atual .
} 
E mereço esperar mais do que os outros, eu?

Tu não me enganas, mundo, e não te engano a ti.

Da nova pergunta, podemos inferir a lembrança trazida do passado (" $E$ mereço esperar mais do que os outros [mereceram]?) considerada por quem lembra e sabe. Assim, a questão que já sugere em si a resposta traz consigo a experiência, o lembrar-se dos "outros", provavelmente esquecidos. ${ }^{55}$ No mundo em que o esquecimento é moeda corrente, é natural colocar-se no lugar do outro a ser esquecido. No final da pergunta, "eu" ressoa, em rima, "esqueceu" ("o tempo esqueceu"), antecipando o que o poeta supõe: ele também será esquecido.

A oposição entre o poeta e o "tempo", da estrofe anterior, ocorre agora entre o poeta e o "mundo". O segundo verso, dessa estrofe, recupera pela rima final o último, da primeira estrofe, onde se descrevia a atitude de desprezo do "tempo" em relação ao poeta. Assim temos:

na primeira estrofe:

["o tempo esqueceu"]

"minha incerta medalha / e a meu nome se ri".

na segunda estrofe:

"Tu não me enganas, mundo,/ e não te engano a ti"

Enquanto entre o poeta e país havia uma reciprocidade positiva, o mesmo não acontece entre o poeta e o mundo. A atitude desdenhosa do tempo, que "ri", é recuperada pela rima determinando também o descaso do mundo em relação ao

\footnotetext{
${ }^{55}$ Como observa o crítico Vagner Camilo, em sua análise de "Legado", Drummond expõe esta sua "visão desenganada" quanto ao reconhecimento público, em "Apontamentos Literários", de Passeios na llha, onde o poeta fala "a respeito das oscilações constantes da 'bolsa de valores intelectuais', tão 'emotiva e calculista, como todas as bolsas: se hoje temos talento; amanhã não mais; se éramos bons poetas em determinadas circunstâncias, em outras somos demasiadamente herméticos ou vulgares; demasiadamente comprometidos pelo nosso individualismo ou pelo nosso socialismo [...] o público não nos decifra: apóia ou despreza, simplesmente'.". In: Drummond, da Rosa do Povo à Rosa das Trevas. São Paulo: Ateliê Editorial, 2001, p.186.
} 
poeta ("ti"). O tempo (breve, do presente) que esquece e o mundo que (não) engana (também no presente) opõem-se ao poeta. Até mesmo o que seria futuro, (o tempo rirá), já é presente, que "se ri". Futuro e passado não são considerados pelo mundo e pelo tempo presente, que esquecem e riem. A oposição entre poeta e mundo/tempo presente afasta-nos ainda mais do plano da especulação afetiva do início. A esse plano opõe-se o do merecimento e da medalha incerta.

Oposto ao mundo/tempo presente que tentam enganar e que esquecem (onde não há lugar para lembranças), ecoando "eu"/ poeta (primeiro verso), temos Orfeu $^{56}$ no terceiro verso.

Esses monstros atuais não os cativa Orfeu,

A vagar, taciturno, entre o talvez e o se.

O poeta não engana o mundo, assim como Orfeu também não cativa "esses monstros atuais". Ambos fracassam. A proximidade entre os dois se dá, além da rima e da oposição frente ao mundo/tempo presente, na causa do fracasso: ambos não conseguem seduzir os monstros atuais, não os enganam nem os cativam, enfim, não os tocam.

Esses monstros, embora remetam à mitologia, aos enormes animais contra os quais lutava Hércules etc, não são transformados mais pelo canto pacífico de Orfeu, são monstros atuais. Eles não só pertencem ao presente, mas estão inteiramente presos a ele: os monstros atuais esquecem o passado e inibem a criação poética que considera o futuro. Se tomarmos ainda o sentido etimológico de atual - relacionado à prática -, temos a sugestão da ação imediata cuja experiência desenvolve-se no próprio ato, dispensando a abstração da experiência anterior, distante, portanto, da ação do poeta, provinda de sua experiência do passado, que determina seu passo, identificado ao de Orfeu, cuja característica,

\footnotetext{
${ }^{56} \mathrm{O}$ poder de encanto de Orfeu sobre homens e animais, cativando-os pelo canto, é talvez mais conhecido do que o mito de Orfeu, que desce ao Inferno à procura de Eurídice, usando também o seu dom para convencer Hades e Perséfone. O canto é, também ele, mais uma recorrência dos poemas de Claro enigma. Para ficarmos só nos títulos, temos: "Cantiga de enganar", "Canção para álbum de moça" e "Canto negro". Os "cantos", aliás, estão nos livros de poemas de Drummond, desde Alguma poesia.
} 
por sua vez, é "vagar taciturno entre o talvez e o se". Diferentemente do poeta que, vivenciando o passado ("quanto senti"), lembra e sabe -, eles zombam da experiência passada ("sentir") enquadrando-se exclusiva e anormalmente à mentalidade e à tendência vigente.

Esse $\operatorname{vagar}^{57}$ discreto, de poucas palavras entre o talvez e o se associa a atitude errante do poeta/Orfeu tanto ao modo Infinitivo dos verbos ("vagar") - o mais indeterminado dos modos, porque pode se processar em qualquer tempo, e também o mais determinado deles porque nomeia a ação -, como ao Subjuntivo ("talvez"), relacionado às probabilidades e aos desejos, e ao Condicional ("se"), que impõe restrições. Acrescenta-se a esses modos o Indicativo, relacionado também, e logo na abertura do poema, à efetivação das ações nos diferentes tempos: o futuro (“darei"), o presente ("lembro e sei”), o passado ("senti”).

A esse Universo de tempos pelo qual caminha(m) o(s) poeta(s) - e os mitos -, contrapõe-se o "mundo" "desses monstros atuais" agarrado a um único modo e tempo: ao tempo presente, do modo Indicativo, e, mais grave do que isso, agarrado, não à atitude pessoal, mas às tendências vigentes. A pergunta do poeta sobre que lembrança dar a quem lhe deu o que tem só pode ser respondida por ele mesmo, que considera os diferentes tempos: o da memória, relacionado à vida passada; o do presente, relacionado ao agora; o do futuro, relacionado à vida em projeção (que fecha e continua o círculo mítico do tempo). Desse modo, a questão é feita e dirigida a si mesmo, que considera o futuro não como morte, fim de "o quanto" sentiu (sugerida pela expressão "noite do sem-fim"), mas como propulsor de seu passo criativo no presente.

Depois de se posicionar frente ao mundo, trazendo a lembrança de Orfeu, o poeta não só parece responder à questão inicial, mas também demarcar a sua posição frente ao mundo e tempo, no qual se encontra:

Não deixarei de mim nenhum canto radioso,

57 O termo adquire nesse poema acepção semelhante à que o crítico Alcides Villaça dá ao advérbio "devagar" no desenvolvimento de sua análise do poema "Cidadezinha qualquer", de Drummond: "o advérbio labora com sua raiz verbal (vagar), para imprimir à ação de ir um aspecto de errância entre solene e vagabunda". In: Passos de Drummond. São Paulo: Cosac e Naify, 2006, p.40. 
Uma voz matinal palpitando na bruma

E que arranque de alguém seu mais secreto espinho.

O não inicia sua resposta. O terceto ressoa a negatividade já encontrada na primeira estrofe, quando o poeta considerava o descaso do mundo que parece sempre descartar o que não se ajusta à mentalidade e tendências vigentes, o que não é atual.

Dialeticamente, ao negar "um canto radioso", "uma voz palpitando na bruma" "que arranque de alguém seu mais secreto espinho", ele traz para o poema o potencial do canto de Orfeu contrário aos monstros atuais, como uma espécie de voz interna do próprio poeta negada ${ }^{58}$, não por ele, mas pelo mundo. $\mathrm{Na}$ "negação afirmativa", própria da alusão ${ }^{59}$, o poeta recorre a Orfeu, cujo canto é radioso, transformador e identificado, ainda, a Apolo (Deus da beleza e harmonia, o qual Orfeu reverenciava a cada nascer do sol, início de um novo dia).

Se, por um lado o mundo é identificado aos monstros do plano mítico, seres anormais e contrários à natureza, por outro, o poeta traz, mesmo que por alusão, a proximidade, reiterada a cada verso, entre Orfeu e a natureza, sugerindo a sua proximidade e a do próprio homem e a natureza: o canto é radioso, como o sol de Apolo; a voz é matinal e, além disso, palpita na bruma e é capaz ainda de arrancar de alguém o seu mais secreto espinho. O uso do modo subjuntivo fechando a estrofe, após a enumeração do que o poeta diz não deixar, atualiza dialeticamente o desejo potencial de transformação pelo canto "que arranque de alguém seu mais secreto espinho", mesmo que acompanhado pela consciência de sua impossibilidade atual. A expressão "que arranque", aliás, pode ser entendida tantonno sentido de se livrar do espinho como o de reconhecer sua existência.

\footnotetext{
${ }^{58}$ Corroborando esta interpretação, a expressão "Não deixarei de mim", em que há a substituição do verbo "dar" da questão inicial pelo verbo "deixar", desta resposta, poderia talvez ser entendida como aquilo que, por desejo do próprio poeta, não será apartado dele, mesmo que apenas internamente e não como expressão.

${ }^{59}$ Cambiante como a indeterminação do "tudo" que determina o sentir.
} 
A terceira estrofe pode ser entendida, portanto, como início da resposta à questão inicial, na medida em que o poeta declara, aludindo a Orfeu, uma atitude poética frente ao "mundo" que o tenta enganar ou mesmo seduzir; e ainda mais: uma atitude poética que define tanto sua ação presente, como a perspectiva da existência futura de sua criação poética (ou do desejo por ela, insinuado pelo uso do modo subjuntivo).

De tudo quanto foi meu passo caprichoso

na vida, restará, pois o resto se esfuma,

uma pedra que havia em meio do caminho.

A referência a sua atitude no passado e a rima final do verso "De tudo quanto foi meu passo caprichoso" aproximam novamente o poeta ao Orfeu do "canto radioso". Neste último terceto, o "canto radioso" é integrado, também pela rima, à produção artística do poeta, ao seu "passo caprichoso". O adjetivo é revelador: tanto pode significar inconstância, volubilidade - aproximando-se do mundo rival ao poeta -, como cuidado, aplicação, esmero e, ainda, excentricidade, extravagância. ${ }^{60}$ Os significados são bastante diferentes entre si, mas têm como traço comum a determinação ativa que parte do próprio sujeito, mesmo quando se mostra como inconstante.

O destaque da locução adverbial, isolada por vírgula, completando o enjambement - "na vida" -, evidencia a qualidade do "passo" daquele que, à época de Rosa do povo, declarava sua opção por estar "preso à vida", e que agora ainda neste momento, mesmo que de outra forma, parece confirmar esta opção.

A expressão atualiza os dois, poeta e Orfeu, neste lugar de todos os tempos - presente, passado e futuro - ambiente natural dos mitos e das poesias: a vida.

Fechando o soneto, a expressão inicial e determinante "de tudo quanto senti" praticamente volta. Outra vez, indeterminação absorvente e intensidade vêm

${ }^{60}$ Houais, Antônio. Dicionário Houais da Língua Portuguesa. Rio de Janeiro: Objetiva, 2001. 
do passado, mas relacionadas, agora, ao futuro, considerado novamente: "restará".

Tudo quanto (senti) destacava no início o envolvimento sensível do poeta, no passado, ao lado de seu lembrar e saber atuais; ao voltar nesta última estrofe, depois das considerações anteriores - em que o passado, figurado por Orfeu, aparece -, a expressão reintegra, com vigor, a pergunta inicial: "Que lembrança darei ao país que me deu/ tudo que lembro e sei, tudo quanto senti?". Na retomada da questão, a "resposta" liberta-se das limitações do tempo que ri e do mundo dos monstros atuais :

De tudo quanto foi meu passo caprichoso

Na vida, restará, pois o resto se esfuma

Uma pedra em meio do caminho.

A oração explicativa, "pois o resto se esfuma", sugere a dissolução deste "resto", que se "esfuma", ou seja, sugere o esquecimento da criação poética realizada, e mesmo o esquecimento de alguma poesia identificada a "uma voz palpitando na bruma". Mas, insinuando uma outra impressão, "resto", por homonímia, acopla ao seu sentido "restará", da oração principal, o que o transforma em sujeito: o "resto" restará, escapando, surpreendentemente, do esquecimento e pressupondo o futuro. "Restará" traz consigo o "resto". Novamente, contrapondo-se à idéia de morte (a "noite do sem fim"), sugerida agora por "se esfuma", encontramos o canto do poeta. ${ }^{61}$

No futuro, portanto, restaria a poesia identificada ao último verso: "uma pedra que havia em meio do caminho".

"Caminho" ressonando "espinho" reafirma semanticamente a problemática expressa pelo verso ontológico, mas ao mesmo tempo, o som repetido pela rima traz para o final do poema a idéia do desejo enérgico de transformação sugerido pelo uso do modo subjuntivo: "E que arranque de alguém seu mais secreto

\footnotetext{
61 "De tudo ficou um pouco./Do meu medo/ Do teu asco./Dos gritos. Da rosa/ficou um pouco. [...]" In: Rosa do povo, "Resíduo", op. cit., p.102.
} 
espinho", como se a consideração do obstáculo contivesse em si mesma senão a possibilidade de resolução, mas o desejo por ela; não se nega o problema, tampouco o desejo particular, mesmo que de maneira potencial, de mudança (pulsão de todo capricho). A determinação particular do "passo caprichoso", cuja inconstância é efeito da inconstância do próprio mundo, continua.

É interessante notar que a resposta à questão inicial, parece-me, marca a constatação dele, poeta, sobre o que ficará de sua poesia, à revelia mesmo do que ele faça. "Uma pedra que havia em meio do caminho", símbolo reduzido por muitos à negatividade, complementando o verbo ("restará"), pode ser a resposta. O verso retoma um dos mais populares de Drummond ("no meio do caminho tinha uma pedra"), que inclusive, independente do próprio poema do qual faz parte, ("No meio do caminho") firmou-se como imagem de problema na fala coloquial; o mesmo verso serviu aos críticos que reduziam a poesia de Drummond ao topos do ferro, da negatividade, causando a irritação natural do poeta. ${ }^{62}$

Enfim, o verso seria, aqui, a resposta à pergunta inicial e poderia, por esse motivo, ser considerado irônico por se relacionar àqueles críticos cujas restrições não sobreviveriam à lembrança do verso, ou, por outro lado, indicar a impotência do poeta frente ao modo como sua poesia é avaliada. Mas considerar essas hipóteses, sobretudo a segunda, é aceitar, de alguma forma, que os versos são movidos pelo desejo da fama, pelo desejo da aprovação dos outros, pela busca das "medalhas", ou aceitar um conformismo do poeta, que também destoa da especulação inicial.

A resposta à questão inicial considera a atividade poética frente ao mundo atual. A força motriz dessa poesia é a consciência da falta que ganha, em vigor, justamente por conseguir, pela alusão, mostrar-se, não como entrave, mas como

\footnotetext{
62 O verso retoma o poema "No meio do caminho", cuja polêmica entre os críticos gerou uma série de textos, sobretudo nos anos quarenta, após o aparecimento da "geração de 45" e da demissão de Drummond. O grande volume das críticas, caricaturas, partitura de música, outros poemas etc. dirigidos a essa produção que "corre o mundo e é considerada ora obra de gênio, ora monumento de estupidez", conforme salienta Drummond, deu origem à biografia do poema, organizada pelo próprio poeta, na qual ele inclui, entre as várias referências a "No meio do caminho", o poema "Legado". Cf.: Uma pedra no meio do caminho. Biografia de um poema. Rio de Janeiro: Editora do Autor.
} 
potência. Sua expressão parte da conjunção dialética com o que falta - canto de Orfeu -, afirmado em sua negação. A força dessa poesia não vem do que "oferece" o mundo breve, das condecorações, mas sim do desejo da transformação do sentimento em saber e lembrança, em legado, finalmente.

\section{Legado e o mito de Orfeu}

Em um mundo regido pelo presente do indicativo, sempre breve, cuja marca é o esquecimento, não se promove lugar para a transmissão da experiência, para a recuperação do que foi esquecido. Em "Legado", o poeta deslocado, sempre gauche, como Orfeu, entre o "o talvez e o se", em um outro espaço de tempo, quem sabe o das possibilidades ou o da realização dos desejos/ ("que arranque") reconhece o valor da experiência, assim como o da memória, determinando o seu passo

Nesse jogo do poema, entre o afetivo e o desdenhoso, quem pergunta e responde é aquele cuja consciência vem do que lhe foi dado pelo país no passado ("tudo quanto" sentiu) e que se atualiza no presente: lembrar e saber (ações reveladoras das capacidades de recuperar e saborear, trazer de volta e experimentar).

Em "Legado" a ação transforma-se em nome, o fazer poético é também ele o "Legado" deixado pelo poeta, é processo que se transforma em objeto, em poema. É atividade criadora e, neste sentido, transformadora também. O pronome indefinido, que passa a definir, e a ação "restará", transformada em substantivo, em "resto", libertando-se do estado de dicionário, espelham os passos do poeta, definidos de acordo com o que ele, poeta, percebe na vida; não se deixando enganar pelo que, no mundo, não se identifica ao seu canto íntimo de Orfeu. As palavras deixam o seu "estado de dicionário" pela ação de seu olhar, que consegue harmonizá-las objetivamente, através do sentimento. Olhar capaz de, como observou Otto Maria Carpeaux sobre a poesia de Drummond, transformar a "agonia em elegia"63.

\footnotetext{
${ }^{63}$ Carpeaux, Otto Maria."Fragmento sobre Carlos Drummond de Andrade”, in: Origens e fins. Rio
} 
Além da referência direta a Orfeu, "noite do sem fim" e passo "taciturno" sugerem a morte e, neste contexto, a descida de Orfeu ao Inferno à procura da amada morta e a conseqüente criação do Orfismo. Aliás, o verso retomado por Drummond, "uma pedra que havia em meio do caminho", recorda-nos o início da primeira parte da Divina Comédia, de Dante, em que o poeta caminha pelo Inferno.

O Orfismo, religião fundada pelo músico e cantor à revelia da religião oficial, considerava o corpo humano como um túmulo para a alma. A morte não significava o fim da existência, mas uma possibilidade de sair do sofrimento da vida enclausurada. Diferente da religião oficial e do que encontramos nas epopéias de Homero, o Orfismo indicava a possibilidade de se aproximar dos deuses.

Uma das condições para os iniciados merecerem o plano divino, após o período de expiação na terra, era lembrar-se das palavras que Ihes haviam sido transmitidas e do caminho a escolher no reino de Hades. A memória, como senha, abriria os caminhos para o encontro com os deuses. Apenas aqueles que lembrassem o que Ihes fora transmitido poderiam atravessar pela morte e conviver com os deuses, livrando-se também do Inferno ou de voltar ao mundo em um outro corpo, considerado como período de expiação (que poderia ocorrer no corpo do réptil mais peçonhento).

Para Guthrie, Simmone Jacquemard e Reynaldo Sorel a causa da descida de Orfeu ao inferno, ou seja, a morte de Eurídice, é de pouca ou nenhuma importância. A questão principal para eles, de maior importância também em "Legado", é a do significado disso. Para Reynaldo Sorel,

Orfeu vindo sozinho do domínio dos mortos renasce dentro da diferença (ele não é mais "o mesmo" que desceu ao inferno) e do sofrimento. A ascensão (renascimento|reencarnação) é muito de Janeiro: Casa do Estudante, 1943. 
freqüentemente ocultada em proveito da descida (morte, ou seja, a alma colocada no cruzamento da vida feliz - às custas da memória - ou do retorno à vida terrestre, metensomatose provocada pelo esquecimento).

Esta nova vida é uma ferida, uma errância, uma solidão, uma dolorosa quebra. Mas Orfeu é mais "consciente" (iniciado) do irreparável que cometeu esquecendo a lei de Perséfone. Esta é a razão pela qual seu mito, perfeita ilustração da metensomatose, incita os homens a cultivar as virtudes da memória dos ritos a cumprir, do caminho a seguir (tanto sobre a terra como em Hades) e as palavras a serem ditas para dirigir-se à divindade original e libertar-se da roda dos nascimentos que faz voltar o sopro contínuo da imortalidade da alma. ${ }^{64}$ [grifo meu]

A memória é tomada como condição para convivência com os deuses, símbolo de uma vida feliz, ao mesmo tempo em que o esquecimento implica uma vida de expiação. Assim, o mito de Orfeu identifica-se à origem da cultura enquanto esta guarda o sentido de passagem do conhecimento de uma geração para outra, de um povo para outro, de preservação da memória. ${ }^{65}$

Evocar Orfeu é ao mesmo tempo evocar toda uma tradição e a importância disso para, de alguma forma, transcender a condição mortal.

Como sabemos, a memória da família, dos amigos, de Minas é marcante nos poemas de Drummond ${ }^{66}$. Em Claro enigma, ela é titulo de um dos poemas ${ }^{67}$; está também em "Remissão"68, outro soneto do início do livro; em "Tarde de maio"69, em "Museu da inconfidência"70, em "Permanência"71 e nos dois últimos

\footnotetext{
${ }^{64}$ Sorel, Reynal. Op. cit., p. 28.

65 Talvez por isso a criação da escrita, cuja origem data da mesma época em que Orfeu teria vivido, por volta do séc. VI a.C., seja atribuída a ele. Orfeu teria transcrito os seus próprios poemas, encontrados há poucas décadas atrás.

66 "Confidência do Itabirano" (Sentimento do mundo), "Retrato de família" (Rosa do povo), "No país dos Andradas" (Rosa do povo) etc.

67 "Amar o perdido/deixa confundido/este coração.//Nada pode o olvido/contra o sem sentido/apelo do não.//As coisas tangíveis/tornam-se insensíveis/à palma da mão.//Mas as coisas findas,/muito mais que lindas,/estas ficarão."

68 "[...]Tua memória, pasto de poesia, /tua poesia, pasto dos vulgares. [...]."

69 "[...]O próprio amor se esconde, ao jeito dos bichos caçados;/não está certo de seu amor; há tanto lavou a memória/das impurezas de barro e folha que repousava. [...]."

${ }_{71}^{70}$ São palavras no chão/E memória nos autos./As casas ainda restam, /Os amores ainda não.

71 "E o esquecimento ainda é memória, e lagoas de sono/selam em seu negrume o que amamos e
} 
poemas que fecham Claro enigma: "A máquina do mundo"72 e em "Relógio do Rosário"73.

Há também, em Claro enigma grande incidência de poetas relembrados seja de maneira direta, já nos títulos dos poemas: "Sonetinho do falso Fernando Pessoa" e "Quintana's Bar", ou indireta, de maneira ora mais, ora menos explícita. Em "Aniversário", há a lembrança do amigo morto há pouco tempo, Mário de Andrade, com quem Drummond manteve correspondência durante longo tempo: "[...]Este menino malasártico |Macunaíma de novo porte, lescreve cartas no ar fantástico | para compensar tua morte.[...]". Manuel Bandeira é lembrado em vários poemas. Está em "O chamado" : "[...] a que Pasárgada, a que abrigo [...]", e na abertura de Claro enigma - "Dissolução" -, onde o último verso faz lembrar a chave de ouro de "Momento no café" : "E sem alma, corpo, és suave", e em "Entre o ser e as coisas", que nos traz à memória "A onda" ("Aonde anda a onda | a onda ainda anda"), logo no primeiro verso: "Onda e amor, onde amor, ando indagando[...]", lembrando ainda Oswald de Andrade e seu "amor humor". Rilke está em "Aspiração":

\footnotetext{
Já não queria a maternal adoração

que afinal nos exaure, e resplandece em pânico,

tampouco o sentimento de um achado precioso

como o de Catarina Kippenberg aos pés de Rilke
}

Fernando Pessoa volta, em "Cantiga para enganar": [...]O mundo não vale a pena | mas a pena não existe.[...]".

Diferentemente do tempo dos monstros atuais, do tempo que tudo esquece,

\footnotetext{
fomos um dia,/ou nunca fomos, e contudo arde em nós/à maneira da chama que dorme nos paus de lenha jogados no galpão."

72 " [...]e a memória dos deuses, e o solene/sentimento de morte, que floresce/no caule da existência mais gloriosa,/tudo se apresentou nesse relance/e me chamou para o seu reino augusto,/afinal submetido à vista humana".

73 "[...] dor de tudo e de todos, dor sem nome,/ativa mesmo se a memória some. [...]"
} 
o poeta novamente recupera o passado que continua no presente, através dos legados deixados também por esses outros poetas, que devem permanecer, como o canto de Orfeu.

A lembrança, que em "Legado" aproxima poeta e país, é freqüente em toda a obra de Drummond, especialmente em Claro enigma. Os versos

Agora me lembra um, antes me lembrava outro

dia virá em que nenhum será lembrado

abrem, em contraponto, o poema "Permanência"; "que relembramos?" é questão de "Perguntas em forma de cavalo-marinho". A lembrança faz parte do jogo de "Cantiga de enganar":

O mundo não vale a pena,

mas a pena não existe

De sofrer e de olvidar

de lembrar e de fruir

de escolher nossas lembranças

e revertê-las acaso

se lembrem demais em nós."

e é evocada em "Carta":

[...] quando só há lembrança,

ainda menos pó, menos ainda, nada, [...]

A lembrança está também nas recordações de "Mesa":

[...]interrogavas em ti

uma lembrança saudosa e não de todo remota [...].

Essa lista de versos é apenas um indício da importância da memória na 
poesia de Drummond ${ }^{74}$. Todos esses fragmentos de poema, em que passeiam parentes, amigos, lugares, épocas, ou seja, experiências que se repetem a cada leitura, como os mitos que entram pelas brechas do tempo histórico, confirmam a importância do fazer poético enquanto expressão de vida no poema, oposto a "esses monstros atuais" - contra os quais reage $(\mathrm{m}) \mathrm{o}(\mathrm{s})$ poeta (s) (gauches) -, próximos daqueles a quem o poeta expõe sua queixa; fazer que parte da vida no mundo e que devolve a ele a subjetividade desprendidamente objetivada.

Neste sentido é válido mencionar a importância da recuperação do passado "trazido pela memória afetiva" para a elaboração poética sobre a qual trata o crítico Antonio Candido, quando se refere a uma das inquietudes de Drummond, traduzida pela procura de conciliação entre "as perspectivas sociais de Sentimento do mundo"75 :

O passado, trazido pela memória afetiva, oferece farrapos de seres contidos virtualmente no eu inicial, que se tornou, dentre tantos outros possíveis, apenas o eu insatisfatório que é. Ora, o passado é algo ambíguo, sendo ao mesmo tempo a vida que se consumou (impedindo outras formas de vida) e o conhecimento da vida, que permite pensar outra vida mais plena; é portanto com os fragmentos proporcionados pela memória que se torna possível construir uma visão coesa, que criaria uma razão de ser unificada, redimindo as limitações e dando impressão de uma realidade mais plena. Esta razão-de-ser poderia consistir na elaboração da obra de arte, que se apresenta como unidade alcançada a partir da variedade e justifica a vida insatisfatória, o sofrimento, a decepção e a morte que se aproxima:

Que confusão de coisas ao crepúsculo!

Que riqueza! Sem préstimo, é verdade.

Bom seria captá-las e compô-las

num todo sábio, posto que sensível:

\footnotetext{
${ }^{74}$ Cf.: Villaça, Alcides. Passos de Drummond. "Pensando-se agora nos enquadramentos próprios da memória, pode-se falar num memorialismo poético de Drummond, na soma de todos os poemas cuja matéria e cujo processo nasçam do interior de uma lembrança. Poemas como "Infância", "Viagem à família" e "As três compoteiras", por exemplo, poderiam agrupar-se no mesmo tópico geral de memorialismo, numa antologia, a despeito dos intervalos de tempo e das diferenças formais que os separam. Mas esses poemas, em que a memória tem um papel decisivo, não se distanciam apenas quanto à época de origem e à forma final: distanciam-se também quanto à qualidade mesma da memória em que se produziram, ou seja, distinguem-se quanto à pluralidade dos humores (em sentido lato) que vão constituindo formas de lembrar." Op.cit. p. 110.

75 "Inquietudes na poesia de Drummond" in Vários escritos. São Paulo: Livraria duas cidades. $3^{\circ}$ ed., 1995, p.116-7.
} 
Uma ordem, uma luz, uma alegria

Baixando sobre o peito despojado.

E já não era o furor dos vinte anos

nem a renúncia às coisas que elegeu,

mas a penetração do lenho dócil,

um mergulho em piscina, sem esforço,

um achado sem dor, uma fusão,

tal uma inteligência do universo

comprada em sal, em rugas e cabelo. ["Versos a boca da noite"] [grifo meu]

A especificidade do canto ("radioso") e o rigor da composição do soneto lembram Apolo; o sentimento que move o poeta lembra Dionísio; assim, os dois deuses identificados a Orfeu se fazem presentes, marcados pela valorização da memória e pela consideração da morte, por aquele cujo passo na vida é taciturno.

A negatividade aproxima vida a sofrimento, sobretudo se pensarmos no descontentamento e frustração profundos de Drummond que, como observam alguns críticos, fazem-no se "afastar da praça dos poderes"76 ou voltar-se para uma poesia "metafísica"77. Apesar de, em "Legado", a vida não ser tomada como período de expiação, penitência por faltas cometidas, como era vista pelos órficos, a preservação da memória representa para o poeta, como para os seguidores de Orfeu, um meio de combater o sofrimento. Enquanto preservar a memória significa para os órficos um meio de promover uma aproximação com os deuses, depois da morte, para o poeta, preservar a memória significa promover um encontro consigo mesmo, que se transforma em força motriz de sua ação, na vida. Não se trata de preservar palavras-chaves sem ligação com a experiência no mundo - por pior que este seja -, para alcançar depois da morte o convívio com os Deuses, livrando-se da permanência no Inferno ou da volta ao mundo terreno, visto como expiação. Diferentemente dos órficos, a memória valorizada por Drummond não é tomada como instrumento para a convivência fora da vida na terra, mas como instrumento para se reconhecer no presente.

\footnotetext{
${ }^{76}$ Camilo, Vagner. Op. cit.

${ }^{77}$ Merquior, José Guilherme. Op. cit.
} 
A "lembrança" deixada pelo poeta ao país que lhe deu "tudo" é o seu "legado". Legado de quem não esquece o que leu - como a escolha de se expressar através de um soneto, forma negada na primeira fase do Modernismo, sugere - nem onde vive ${ }^{78}$, como demonstra sua crítica aos "monstros atuais". A memória para Drummond é parte integrante - diretamente relacionada ao sentir -, do que se traduz em poema graças à capacidade de recuperação poética do passado pelo trabalho artístico, marca da figura síntese (apolínea e dionisíaca) que é Orfeu. A obra do poeta tem origem na intensidade do sentimento, propulsor do que é lembrado e sabido (e também atualizado) por ele, ou seja, do que foi de alguma forma vivenciado pelo coração e vaza o mundo "desses monstros atuais", em sua concretização: o poema.

\footnotetext{
${ }^{78}$ As duas expressões em itálico retomam uma afirmação de Caetano Veloso ao se referir a sua
} atuação na vida pública do Brasil: "Não posso esquecer o que li, nem onde vivo". 
"CANTO ÓRFICO", de Carlos Drummond de Andrade

A dança já não soa,

a música deixou de ser palavra,

o cântico se alongou do movimento.

Orfeu, dividido, anda à procura

dessa unidade áurea, que perdemos.

Mundo desintegrado, tua essência

paira talvez na luz, mas neutra aos olhos

desaprendidos de ver; e sob a pele,

que turva imporosidade nos limita?

De ti a ti, abismo; e nele, os ecos

de uma prístina ciência agora exangue.

Nem tua cifra sabemos; nem captá-la

dera poder de penetrar-te. Erra o mistério

em torno do seu núcleo. E restam poucos

encantamentos válidos. Talvez

um só e grave: tua ausência

ainda retumba em nós, e estremecemos,

que uma perda se forma desses ganhos.

Tua medida, o silêncio a cinge e quase a insculpe, braços do não saber. Ó fabuloso

mudo paralítico surdo nato incógnito

na raiz da manhã que tarda, e tarde,

quando a linha do céu em nós se esfuma

tornando-nos estrangeiros mais que estranhos. 
No duelo das horas tua imagem

atravessa membranas sem que a sorte se decida a escolher. As artes pétreas recolhem-se a seus tardos movimentos. Em vão elas não podem

Amplo

vazio

um espaço estelar espreita os signos

que se farão doçura, convivência, espanto de existir, e mão completa caminhando surpresa noutro corpo.

A música se embala no possível, no finito redondo, em que se crispa uma agonia moderna. O canto é branco, foge a si mesmo, vôos! Palmas lentas sobre o oceano estático: balanço de anca terrestre, certa de morrer.

Orfeu, reúne-te! Chama teus dispersos e comovidos membros naturais, e límpido reinaugura o ritmo suficiente, que, nostálgico, na nervura das folhas se limita, quando não compõe no ar que é todo frêmito, uma espera de fustes, assombrada. 
Orfeu, dá-nos teu número

de ouro, entre aparências

que vão do vão granito à linfa irônica.

Integra-nos, Orfeu, noutra mais densa

atmosfera do verso antes do canto,

do verso universo, latejante

no primeiro silêncio,

promessa de homem, contorno ainda improvável

de deuses a nascer, clara suspeita

de luz no céu sem pássaros,

vazio musical a ser povoado

pelo olhar da sibila, circunspecto.

Orfeu, que te chamamos, baixa ao tempo

e escuta:

só de ousar-se teu nome, já respira

a rosa trismegista, aberta ao mundo ${ }^{79}$

${ }^{79}$ Andrade, Carlos Drummond de. Op. cit., p. 213. 
[Morte] - O que você entende por poeta?

[Poeta] - O poeta, compondo seus poemas, usa uma língua, nem viva, nem morta, que poucas pessoas falam e poucas pessoas entendem.

[Morte] - E por que essas pessoas usam essa língua? [Poeta] - Para encontrar seus compatriotas, num mundo em que $o$ exibicionismo freqüentemente é exercido por exibicionistas cegos.

[O testemunho de Orfeu, Jean Cocteau.]

\title{
O CANTO ÓRFICO
}

A perda é o mote da descida de Orfeu ao inferno e do "Canto órfico" de Drummond:

\begin{abstract}
A dança já não soa,
a música deixou de ser palavra,

o cântico se alongou do movimento.

Orfeu, dividido, anda à procura

dessa unidade áurea, que perdemos
\end{abstract}

Dança e movimento, música e som; canto e palavra. A dança realiza-se com o movimento; a música é composta pelo som; o cântico é formado por palavras. $O$ trocadilho invertendo essas relações e marcado pela negatividade, logo no início do poema, sublinha a perda da unidade das $\operatorname{artes}^{80}$ e da interrelação entre elas, assim como faz pressupor uma unidade anterior positiva. Do mesmo modo, o aposto, determinando Orfeu, e a oração adjetiva ("que perdemos"), determinando nós, pressupõem uma unidade procurada por Orfeu

\footnotetext{
${ }^{80}$ A observação do trocadilho na referência às diferentes artes foi observada por Alcides Villaça. André Luís Rodrigues, em sua análise desse poema [trabalho de conclusão de curso de graduação, gentilmente confiado a mim por André, a quem agradeço muito] também observa: "Esta primeira estrofe poderia ser definida pela perda: se "a dança já não soa", ela certamente já soou um dia; se a música deixou de ser palavra", ela algum dia já o foi; se "o canto se alongou do movimento", ele esteve algum dia dele próximo. Estes três versos parecem referir-se a um tempo mítico, em que as artes não estavam distanciadas [...]".
} 
(“dividido”) e perdida por nós.

\begin{abstract}
Mundo desintegrado, tua essência
paira talvez na luz, mas neutra aos olhos

desaprendidos de ver; e sob a pele,

que turva imporosidade nos limita?

De ti a ti, abismo; e nele, os ecos

de uma prístina ciência, agora exangue.
\end{abstract}

"Mundo desintegrado", por sua vez, também faz supor uma perda de unidade, identificando-se às artes, a Orfeu e a nós. Se em "Legado", o poeta se colocava em franca oposição ao Mundo: "Tu não me enganas, mundo, e não te engano a ti.", agora a relação com o mundo, além de conflituosa, envolve não só o poeta, mas também, de maneira mais evidente ${ }^{81}$, o leitor ou as pessoas que, inconformadas como ele, tentam decifrar o Mundo:

[...] e sob a pele, | que turva imporosidade nos limita?

[...] Nem tua cifra sabemos; nem captá-la | dera poder de penetrar-te.

As negativas continuam. Desde o início até o verso dividido "amplo / vazio", o poeta trava embate com o "Mundo" expondo tanto as perdas do "Mundo desintegrado", como também a dos olhos "desaprendidos de ver", que, por sua vez, tanto podem ser olhos do mundo como os olhos do poeta ou mesmo os nossos. De qualquer forma, a estrofe é marcada pela impossibilidade de comunicação entre o "mundo desintegrado", o poeta e "nós". Se, por um lado, é sugerida ("talvez") uma "essência" do "mundo", que "paira na luz", por outro, os "olhos", "desaprendidos de ver", e a "imporosidade" "sob a pele" impedem a penetração dessa luz, seja pelo olhar ou pela pele. Do mesmo modo que a "essência" do "mundo" não chega até nós, há também a incapacidade desse nós

\footnotetext{
81 A referência ao leitor, em "Legado", aparece textualmente apenas na referência a "esses monstros atuais", indicando o distanciamento do poeta e ao mesmo tempo a maior proximidade dos leitores (ou das pessoas a quem ele dirige o poema) em relação aos "monstros atuais".
} 
de se aproximar desta essência: "De ti a ti, abismo" .

A consciência da falta, gerada pela percepção das negativas ("imporosidade", "limitação", "exangue") acentua o valor do que já foi perdido, ou seja, da integração, do aprendido, da porosidade, do ilimitado etc. e sugere, ao mesmo tempo, uma unidade perdida do "mundo" portador também de uma essência existente, embora não percebida, como ocorre com as artes.

\footnotetext{
Nem tua cifra sabemos; nem captá-la

dera poder de penetrar-te. Erra o mistério

em torno do seu núcleo. E restam poucos

encantamentos válidos. Talvez

um só e grave: tua ausência

ainda retumba em nós, e estremecemos

que uma perda se forma desses ganhos.
}

É importante observar que, apesar de o poeta ainda dialogar com Mundo ${ }^{82}$, as palavras "cifra", "encantamentos", "grave" (que junto a "só" pode sugerir a nota "sol") e a expressão "retumbar em nós" evocam Orfeu; assim, a "ausência" - um dos "poucos/encantamentos válidos" - do "Mundo" "desintegrado" traz com ela a percepção, algo inconsciente, de Orfeu (ou de sua ausência tida como perda). ${ }^{83}$

Após o relato das perdas, é, inesperadamente, a "ausência", sinônimo de falta ou vazio, que parece sugerir, senão uma saída, mas uma nova avaliação do que (não) se vê. A ausência significante leva-nos a reavaliar "abismo", outro termo associado à falta, vazio etc ${ }^{84}$; e a conclusão é a de que também ele pode ter seu "estado de dicionário" transformado pelo poema. No "Canto órfico", "abismo" aponta uma possibilidade de comunicação entre "mundo" e "nós" ou entre "mundo" e si próprio:

De ti a ti, abismo, e nele, os ecos de uma prístina ciência, agora exangue.

\footnotetext{
${ }^{82}$ O pronome possessivo confirma isso.

${ }^{83}$ Talvez a ausência de "uma voz matinal palpitando na bruma".

84 "[...]precipício, profundeza, [...] incomensurável.Tudo o que é insondável, misterioso, grande distância, profunda separação, situação difícil, insustentável, caos inferno. Dicionário Houais, op. cit.
} 
Se tomarmos "prístina ciência" como a "gaia ciência" dos trovadores do séc. XII, O "abismo" pode ser a possibilidade de ouvir os "ecos" das antigas cantigas, acompanhadas pela dança e música, surgindo novamente a alusão a Orfeu, vinda desta vez pelas cantigas e também pelos "ecos", enquanto repetição de sons, própria do canto.

O conflito amplia-se na quarta estrofe, quando o incômodo do mistério do Mundo provoca o desabafo vindo em nova série de negativas:

\author{
[...]Tua medida, o silêncio a cinge e quase a insculpe \\ braços do não saber. Ó fabuloso, \\ mudo paralítico surdo nato incógnito \\ na raiz da manhã que tarda, e tarde, \\ quando a linha do céu em nós se esfuma, \\ tornando-nos estrangeiros mais que estranhos
}

e continua ainda na quinta estrofe, que se divide em duas dividindo também o poema em dois momentos bastante distintos:

\footnotetext{
No duelo das horas tua imagem

atravessa membranas sem que a sorte

se descida a escolher. As artes pétreas

recolhem-se a seus tardos movimentos.

Em vão: elas não podem.
}

"No duelo das horas" a "imagem" do "mundo" "atravessa membranas" parecendo abrir uma via de comunicação entre o poeta/nós e o "mundo", antes inexistente, a não ser, paradoxalmente, pelo "abismo", que separava "mundo" de nós (ou dele mesmo: "De ti a ti, abismo", excluindo tanto o poeta como "nós").

Do abismo saem "os ecos/ de uma prístina ciência agora exangue"; na "ausência que retumba em nós" se encontra um dos poucos "encantamentos validos" que "restam" para uma possível comunicação entre poeta/nós e "mundo". Subliminarmente, aparece Orfeu sugerindo, mesmo no trecho mais dramático do 
poema, um outro modo de olhar.

"Abismo", que à primeira vista indicava impossibilidade, surge, pela construção poética, como possibilidade. É essa mesma sensação, de respiro, que temos ao passar pelo espaço em branco graficamente sugerido:

amplo

vazio

após a constatação da impossibilidade das "artes pétreas".

A diferença de tom entre a primeira e a segunda partes do "Canto órfico" é flagrante. Desde seu início até à metade da quinta estrofe, observamos a impotência do poeta frente às perdas e negatividades sentidas por ele no "Mundo" e, como reflexo, nele ou em nós mesmos. Por outro lado, as referências a Orfeu acompanham a descrição angustiada do poeta; assim, a procura anunciada no início:

Orfeu, dividido, anda à procura

dessa unidade áurea, que perdemos

efetiva-se no próprio poema. Orfeu parece "andar" entre as faltas e negatividades elencadas no diálogo dramático do poeta. O poema começa e termina com referências ao músico.

$\mathrm{Na}$ quarta estrofe, Orfeu continua, na recorrência à medida - termo relacionado ao canto e à poesia - e prossegue ainda pelo uso do verbo "insculpir" que pode significar trazer à memória, faculdade tão cara ao Orfismo, como vimos na análise de "Legado". Aliás, por um triz ("quase"), ou seja, pela falta da atuação da memória o que seria preciso mudar não muda.

Tua medida, o silêncio a cinge e quase a insculpe

braços do não saber. [...] 
Depois de "amplo | vazio" - graficamente sugerido, acentuando a lembrança de "ausência" e "abismo" -, o tom negativo, as perdas e impossibilidades são percebidos de outra maneira, descortinando-nos um novo tom. A série de privações e o duelo transformam-se em canto. Música, canto, ritmo, compõe, musical, poesia, canto branco, verso universo latejante vêm se opor à desintegração, imporosidade e à limitação dos primeiros momentos.

À reiterada negatividade expressa pelas estrofes anteriores ("e tarde", "e grave", "e estremecemos") contrapõem-se o sentimento e a transparência: "e comovidos", "e límpido". A relação conflituosa com o "mundo" dá lugar a uma possível "promessa de homem", impulsionada pela evocação direta de Orfeu, marca definitiva da mudança de tom do poema:

\footnotetext{
Orfeu, reúne-te! Chama teus dispersos

e comovidos membros naturais,

e límpido reinaugura

o ritmo suficiente, que, nostálgico,

na nervura das folhas se limita,

quando não compõe o ar que é todo frêmito,

uma espera de fustes assombrada. [grifos meus]
}

Os imperativos entusiasmados ao invocar Orfeu ("reúne-te", "chama", "reinaugura", "dá-nos", "Integra-nos" e finalmente "baixa ao tempo/ e escuta") sugerem se não a possibilidade do encontro da unidade perdida de uma época de ouro, pelo menos a ousadia da expressão do desejo de mudança determinada por este chamado a Orfeu, capaz de fazer respirar "a rosa trismegista aberta ao mundo". 
Nem tua cifra sabemos; nem captá-la

dera poder de penetrar-te.

Orfeu era capaz de ouvir os sons peculiares a cada um dos seres, fossem eles animados ou não, o que lhe dava a capacidade de escolher o canto exato para cativar homens e animais (por mais selvagens que fossem), rochedos (como aqueles que teriam impedido o avanço dos Argonautas), monstros (como os que vigiavam a morada de Hades) etc.

La poesie est pour lui beaucoup plus qu' un flux lyrique. Elle est saisie du réel par le martèlement des mots apparentés aux sons et les doublant. Orphée connaît le pouvoir de la vibration, et sa poésie encercle, encerre, illumine un fragment de l'espace où toutes choses se meuvent, y compris les dieux. Le mot, le son juste du mot, des mots assemblés, est possiblement, pour qui en connaît le maniement, verbe créateur. Mots et sons fusionnent et forment une nappe magnétique, chargée d'une efficacité qui n'a pas de limites. [...] Orphée connaît lê maniement des mots et des vibrations par eux déclenchées ${ }^{85}$.

Todo o inconformismo do poeta na primeira parte do "Canto órfico" gira em torno da necessidade de adequação de seu canto ao que ele vê, ou talvez fosse melhor dizer, ao que ele não vê. A mudança percebida na segunda parte do poema parece antes uma mudança de atitude frente ao que se via do que uma mudança do que se via. Agora,

A música se embala no possível,

no finito redondo, em que se crispa

uma agonia moderna.

como se o poeta encontrasse não a medida do mundo (ou sua essência?), mas a de seu próprio canto, que, depois de enfrentar o "abismo", parece renascer

85 Jacquemard, Simone e Brosse, Jacques. Op. cit., p. 18-9. 
"noutro corpo". Não há uma mudança do mundo, mas uma mudança da atitude poética após um voltar-se para si mesmo.

Esta virada corresponde a uma mudança subjetiva, por não partir de uma transformação do mundo, mas do sujeito (poeta) frente ao que ele observa (ou não observa). A mudança também não vem por uma oferenda "gratuita" como a de "A Máquina do mundo" ${ }^{86}$, mas parte do encontro do mito dentro do próprio poeta, ou de sua consciência da lamentável ausência de Orfeu no mundo provocando, por isso, a sua ação poética. Os versos decassílabos (assim como o soneto, em "Legado") ainda continuam, remetendo-nos a uma métrica antiga, mas uma nova linguagem encarna os novos sentimentos e percepções do mundo ${ }^{87}$.

No "Canto órfico" de Drummond, a mudança de atitude do poeta frente ao mundo é postura de quem não toma o obstáculo como limite de sua expressão, mas como condição dela; resultado de trabalho constante com as palavras, que continua. Neste sentido, esse poema junta-se a vários outros de Drummond sobre sua atitude poética.

Esse trabalho constante com as palavras está, por exemplo, em "O lutador", que, embora pertencente a um outro contexto histórico, assinala uma preocupação marcante da obra de Drummond. ${ }^{88}$

Lutar com as palavras

é a luta mais vã.

\footnotetext{
${ }^{86}$ Cf.: Análise de "A máquina do mundo" feita pelo crítico Alcides Villaça. "O poeta a máquina e o mundo". In: Passos de Drummond. Op. cit. 77-106.

87 Villaça, Alcides. Lendo poetas brasileiros. Trabalho apresentado para o concurso de Livredocência na FFLCH- USP, 1999, p. 5

${ }^{88}$ Para José Merquior [Op. cit. p. 72]: "Não poderíamos superestimar a significação de 'O lutador' na obra de Drummond. Numa antologia de seus versos, organizada por ele próprio, o poeta transcreve este poema no começo da seção 'poesia contemplada'; o que significa que o considera sua primeira real reflexão em matéria de poética. Desnecessário acrescentar que o 'Lutador' representa um ruptura definitiva com a poética do vivido, sustentada até o Sentimento do mundo. Drummond sabe agora que a poesia 'não é a arte do objeto' (tal como pensava o jovem autor de Alguma poesia), mas antes a 'arte do nome do objeto'".
} 
Entanto lutamos

mal rompe a manhã. [...]

Quisera possuir-te

neste descampado, [...]

Luto corpo a corpo,

luto todo o tempo $[\ldots]$

O ciclo do dia ora se conclui

e o inútil duelo

jamais se resolve. [...]

Cerradas as portas,

A luta prossegue

Nas ruas do sono.

A luta que se dá no descampado e mesmo depois de concluído o ciclo do dia prossegue no sono neste poema, parece continuar em "Canto órfico", no duelo das horas atravessando membranas sem que a sorte decida a escolher, como parece continuar também, no dia seguinte, com o "elefante" de "poucos recursos" 89 , mas de olhos sensíveis atravessando a cidade: "Amanhã recomeço".

O embate aparentemente insolúvel entre poeta e mundo - motor da criação poética - , e a luta com as palavras, que alude a uma transformação possível, mesmo que no plano mítico, são expressos também pelo desenlace inesperado do poema "Áporo", de A rosa do povo, na guinada surpreendente do caminho que parte da dificuldade presente no plano histórico para a alusão positiva ao plano mítico; transformação esta que se dá pelo trabalho incansável e persistente do

\footnotetext{
${ }^{89}$ Cf.: Villaça, Alcides. Passos de Drummond, op.cit., p. 68. "Os 'poucos recursos' confessados já no início da fabricação [do elefante] não expõem a modéstia falsa do grande poeta: falam de sua compreensão das formas mesmas da poesia lírica moderna, penosamente arrancadas de uma tradição exausta de seu abalado prestígio"
} 
"inseto" (poeta) transfigurado pela elaboração poética, em que a disparidade de tamanho entre o sujeito e oponente é fabulosamente vencida. ${ }^{90}$.

A atitude reflexiva do trabalho poético à procura de uma unidade perdida do mundo, de nós e do poeta define a poesia sentimental de Drummond (no sentido dado por Schiller), evidenciada no "Canto órfico" pela presença de Orfeu, na primeira parte, em que ele aparece subliminarmente, e na segunda, em que é tomado como ideal .

[...] o ser natureza do poeta ingênuo representa um dever ser para os poetas sentimentais. Impossibilitados (pela "época em que florescem" ou por "condições acidentais") de ser ingênuos, de criar naturalmente segundo a maneira grega, os poetas modernos têm ali, na natureza ingênua, um objeto a ser buscado, um Ideal de beleza. Ora, é paradoxalmente nesta inferioridade para com o modelo inatingível dos antigos que reside a maior virtude dos modernos. Quando se estabelece como referência entre os dois tipos de gênio não mais a natureza, mas o Ideal que ela representa, estes últimos afirmam toda a sua vantagem sobre aqueles. [...] Ora, é justamente nesse ponto - a busca consciente de um Ideal do gênero humano - que reside a 'superioridade' do sentimental em face do ingênuo $[\ldots]^{91}$

A impressão viva da força da natureza de uma "época de ouro" - talvez aquela definida por Rousseau, em que o homem estava "a meio caminho entre a brutalidade [primitiva] das etapas anteriores e a corrupção das sociedades civilizadas"92 - cantada pelo gregos, em sua "poesia ingênua", perpassa o poema ao lado de Orfeu, dividido, em seu caminho à procura da unidade perdida, da nota certa, transformadora.

Do mesmo modo que a alusão à morte em "Legado" ("noite do sem fim") não paralisa o poeta, a constatação da morte no "Canto órfico", sugerida em

\footnotetext{
${ }^{90} \mathrm{Cf}$. Análise do poema "Áporo" do crítico David Arrigucci Jr. "Dificuldades no trabalho", In: Coração Partido. São Paulo: Cosac \& Naify, 2002. Para o crítico, "Caminho difícil do saber e do mito, 'Áporo' é também o árduo percurso da poesia tal como se espelha na consciência do poeta, debruçada sobre o próprio fazer sem saída".

${ }^{91}$ Cf.: Suzuki, Márcio. "Apresentação" de Poesia ingênua e sentimental, de Schiller. São Paulo: lluminuras. 1991, p.37.

${ }_{92}$ Chauí, Marilena. "Vida e obra" in: Rousseau (Os Pensadores). São Paulo: Nova Cultural. 1999, p.13.
} 
"balanço de anca terrestre certa de morrer", não indica fim, mas pulsão para criação poética, compromissada com o presente e com a vida. Compromissada em achar as cifras.

Assim, reforçando a idéia da luta travada pelo poeta, "prístina ciência", considerada por esta análise como possível "gaia ciência", na primeira parte do poema, quando é determinada como "exangue", pode ganhar um novo sentido, repetindo o que se passa com "abismo" e "ausência". Envolvida pela mudança de tom do poema, ela pode ser identificada ao explicitamente desejado "verso universo latejante", representado pelo "número de ouro" de Orfeu, "entre aparências que vão do vão granito à linfa irônica".

Estrangeiro mais do que estranho

Memória e cultura

Na seqüência de características negativas atribuídas a Mundo, na quarta estrofe do poema, anterior à mudança, a privação continua como traço comum (mudo paralítico surdo nato incógnito). O traço da incomunicabilidade próprio de "imporosidade" repete-se tanto nos "olhos desaprendidos de ver", quanto em "nato incógnito" ou "surdo nato".

A princípio, nato parece deslocado; sozinho, não remete à característica negativa. Ele só passa a ter sentido negativo na associação com o termo anterior ou posterior a ele: lido como adjetivo, qualificando surdo (surdo nato), ou substantivo, sendo incógnito seu adjetivo (nato incógnito). O que parece significativo é que as duas formas dirigidas a Mundo têm como conseqüência em "nós" o sentir-se estrangeiro, ou seja, não identificado ao nascimento (nato) enquanto surdo ou incógnito.

A percepção de tornar-se estrangeiro, mais do que estranho, se dá como 
resultado da percepção da passagem do tempo, vinda após a fala dramática, que a cada estrofe toma mais fôlego, sobretudo pelas orações ou expressões aditivas, iniciadas pela conjunção $e^{93}$. O conflito parece crescer - principalmente depois do uso do vocativo e da aceleração do ritmo provocado pela seqüência de insultos sem virgulas ou conjunção. A revolta acompanha o desabafo talvez dirigido ao mundo, como ocorre nas primeiras estrofes, mas talvez também, pelo uso do termo "estrangeiros", a país: "Ó fabuloso/mudo paralítico surdo nato incógnito". A seqüência de insultos aparta o sentido positivo de "fabuloso", imprimindo a ele os aspectos de inação doentia, a falta de comunicação e, sobretudo por conta de "ignoto", a falta de conhecimento (ou auto-conhecimento), daquele que por vontade própria, ou não, esconde sua identidade. Mas, ao mesmo tempo, a seqüência de insultos faz ver um envolvimento profundo daquele que se exalta.

O termo "fabuloso" remete-nos a um mundo antigo, onde história real e imaginação mítica se mesclam admiravelmente, remetendo-nos, enfim, ao mundo próprio de Orfeu. Tomado como está, é como se "fabuloso" estivesse no "lugar errado"; é como se ele precisasse ser acompanhado ou acompanhar Orfeu, ou seja, como se ele só fosse percebido enquanto admirável, em um outro tom, que também está no poema de Drummond, mas na sua segunda parte do "Canto", quando Orfeu é chamado a descer até nós. Assim, tanto há uma indignação clara como uma alusão positiva em relação a este "fabuloso".

Se considerarmos que "fabuloso", relacionado no poema claramente a mundo, pode relacionar-se também a país - por conta do "desabafo" em que o poeta se vê transformado, junto a "nós", em "estrangeiros mais que estranhos" poderia haver nos dois modos de se tomar este termo, negativa ou positivamente, uma referência às atitudes de Drummond e Mário de Andrade, frente ao Brasil.

A lembrança deste outro poeta (Orfeu) vem também por causa do poema "Mário desce aos infernos", poema de Drummond em homenagem ao amigo, feito logo depois da morte de Mário de Andrade. Além da coincidente referência a

\footnotetext{
93 "e sob a pele, que turva imporosidade nos limita", "e nele", "e grave", "e tarde".
} 
Orfeu, este outro poema de Drummond alude ao empenho do amigo em suas pesquisas sobre a cultura popular brasileira, ao seu mergulho nela. Os versos finais do "Canto órfico", reforçando esta aproximação, remetem também à homenagem a este outro poeta.

A polaridade entre "fabuloso", tido negativa e positivamente, se relacionada a país, pode remeter à discórdia entre Drummond e Mário de Andrade sobre o Brasil, no início da amizade entre os dois poetas. Logo nas primeiras correspondências entre eles, Mário pede que o amigo o acompanhe em seu interesse pelo Brasil:

Carlos, devote-se ao Brasil, junto comigo. Apesar de todo o ceticismo, apesar de todo o pessimismo e apesar de todo o século XIX, seja ingênuo, seja bobo, mas acredite que um sacrifício é lindo [...] Eu vivo e vocês não vivem porque são uns despaisados e não têm coragem suficiente de serem vocês. É preciso que vocês se juntem a nós ou com esse delírio religioso que é o meu, do Osvaldo, de Tarsila [...]Trata-se de ser. E vocês [referindo-se aos poetas de Minas, amigos de Drummond] ainda não são[.... ${ }^{94}$

Em resposta, Drummond escreve:

Pessoalmente acho lastimável essa história de nascer entre paisagens incultas e sob o céu pouco civilizados. Acho o Brasil infecto [...].

Sentindo-se, como descreve José Maria Cançado, biógrafo de Drummond, "no direito de intervir, fraternal, mas direto", Mario de Andrade continua tentando convencer o amigo a mudar de opinião:

A paisagem é inculta de um modo geral, não há dúvida. Mas para você, ela é inculta em relação à Gare d'Orsay e aos bouquins que o sr. Anatole France escarafunchava nos cais horas a fio, para depois arranjar-Ihes literatura. A mesma paisagem que a você desgosta deu-me horas de

${ }^{94}$ Cançado, José Maria. Os sapatos de Orfeu. São Paulo: Globo, 2006, p. 105-6. 
intensa felicidade.

Comentando ainda sobre o "apertado dilema", confessado por Drummond, entre nacionalismo e universalismo - "O nacionalismo convém às massas, o universalismo convém às elites"-, Mário prossegue seus esclarecimentos:

Tudo errado [...]Nacionalismo quer dizer simplesmente: ser nacional. $O$ que mais simplesmente ainda significa dizer: ser [...] E agora reflita bem no que eu cantei no final do "Noturno" e você compreenderá a grandeza deste nacionalismo universalista que eu prego. [grifo $\mathrm{meu}]^{95}$.

Os poucos trechos dessas cartas - que retratam a "falta de adesão" de Drummond ao "nacionalismo do amigo Mário (que não deixou de lhe recriminar o absenteísmo e as excessivas preocupações da inteligência diante da emoção)"96 _ no início da amizade entre os dois, é necessário frisar -, imprimem tanto o entusiasmo de Mário, aberto a um Brasil "fabuloso", como a crítica de Drummond a um Brasil "mudo paralítico surdo nato incógnito".

O mito de Orfeu vem representado em "Canto órfico" pela descrição das perdas - cuja memória faz parte delas ("olhos desaprendidos", "braços do não saber", "incógnitos"). Como vimos, a valorização da memória surge no mito de Orfeu a partir de sua experiência no reino dos mortos. Por causa dela, ele passa a ensinar aos homens um meio de não serem jogados ao fogo de Hades ou às trevas, palavra que, não por acaso, é sinônimo de ignorância, cognata de incógnito, termo usado para definir o "Mundo desintegrado", que termina por gerar no poeta o sentir-se estrangeiro.

Da mesma forma que a passagem pelo inferno origina em Orfeu a valorização da memória - e, por extensão, da cultura -, o voltar-se para si mesmo,

\footnotetext{
${ }^{95}$ Idem. P. 105-6.

${ }^{96}$ Villaça, Alcides. Passos de Drummond. São Paulo: Cosac Naify, 2006.
} 
o confronto com o abismo, com o vazio provocado pelo sentimento de ausência e perda, com a fragmentação - que percebida só faz aumentar o sentimento de uma unidade faltante - lembra também o conflito de Mário de Andrade, de alguma maneira expresso em Macunaíma ${ }^{97}$.

No poema "Mário de Andrade desce aos Infernos", de 1945, que integra $A$ rosa do povo, além da identificação entre Mário de Andrade e Orfeu, salienta-se justamente a importância da memória valorizada por este poeta :

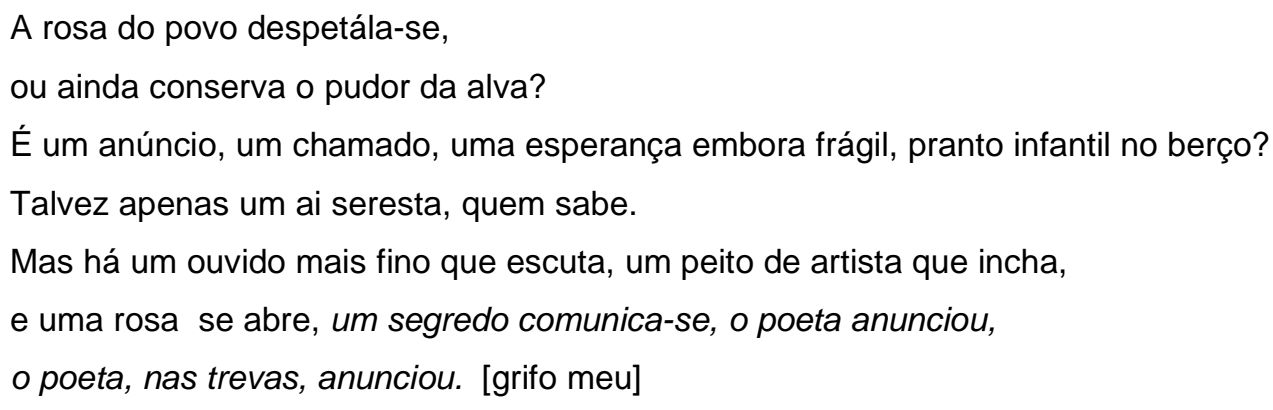

Ao contrário de Orfeu, que depois de perder Eurídice consegue encantar os monstros que o impediam de revê-la, o poeta não encanta o mundo/país "mudo paralítico surdo nato incógnito", mas como o mito, enfrentando "ausência" e "abismo" - o seu Inferno -, promove uma transformação. Nesse sentido, é interessante observar, na primeira parte do poema, o uso da preposição em e da contração nele, as expressões sob a pele ("que turva imporosidade nos limita?"), poder de penetrar-te e ainda retumba em nós, assim como a recorrência do pronome, todos indicando interioridade ou um movimento voltado para o interior (ou no interior), marcando a possibilidade de mudança diretamente relacionada a um voltar-se para si mesmo (ou a um encontro com Orfeu, que "retumba em nós"). Ainda o uso reiterado do advérbio acena uma possibilidade de mudança: "[...] tua essência / paira talvez na luz [...] “, "[...]e restam poucos encanamentos válidos /

\footnotetext{
${ }^{97}$ Cf.: Souza, Gilda de Melo. O tupi e o alaúde: uma interpretação de Macunaíma. São Paulo: Duas Cidades, 1979.
} 
Talvez um só e grave: tua ausência [...]", que também parece depender deste voltar-se para si mesmo. ${ }^{98}$

Pensando na mudança de perspectiva evocada pela segunda parte do "Canto órfico", neste "novo corpo" que parece considerar a persistência e o valor do trabalho poético, apesar de tudo, assim como a necessidade de uma autoavaliação que promova reconhecimento, não parece fora de lugar lembrar deste outro Orfeu, Mário de Andrade, e de suas cartas a Drummond, em que o autor de Macunaíma tentava mudar a impressão do amigo sobre o Brasil e incutir nele a necessidade de se "redescobrir" este país.

Resgatar a memória é sinônimo de sair das trevas, penetrar no que é ignorado e trazê-lo à luz, como fez Mário de Andrade. Com seu "Canto órfico" Drummond parece apontar a urgência de um voltar-se para si mesmo, que pode ser estendido também à urgência vista por Mário, sugerindo um mergulho em nós mesmos, exemplificado pela atitude desse poeta e pesquisador incansável ${ }^{99}$, sobretudo no que diz respeito a pesquisas sobre a música produzida no Brasil.

\footnotetext{
${ }^{98}$ Esta atitude lembra o "conhece-te a ti mesmo" socrático com a diferença de este movimento não ser, neste poema, movido pelo intelecto e razão, mas pelo sentimento provocado pelo conflito. Assim este voltar-se para si identifica-se ao auto-conhecimento definido por Rousseau que aponta o sentimento, conforme expõe Marilena Chauí, como "'faculdade infinitamente mais sublime" do que a razão e como o "verdadeiro caminho para a penetração na essência da interioridade [...] a chave com que se pode conhecer a Natureza e alcançar misticamente o próprio infinito". Para ele, continua a filósofa:"Deixar de lado as convenções da razão civilizada e emergir no fundo da Natureza através do sentimento significa elevar-se da superfície da terra até a totalidade dos 'seres, ao sistema universal das coisas, ao ser incompreensível que a tudo engloba'. Perdido o espírito nessa imensidão, o indivíduo não pensa, não raciocina, não filosofa, mas sente com voluptuosidade, abandona-se ao arrebatamento, perde-se com a imaginação no espaço e lança-se ao infinito. Essa imersão mística no infinito da natureza equivale penetrar na própria interioridade, alcançar a consciência da liberdade e atingir o sentimento íntimo da vida, com a qual o homem teria consciência de sua unidade com os semelhantes e com a universalidade dos seres. No relacionamento místico com a Natureza, segundo Rousseau, não se desfruta nada de externo ao próprio indivíduo e sua existência; durante o lapso de tempo em que ocorre a relação, o homem basta-se a si mesmo, como se fosse Deus". Chauí, Marilena. Op. cit., p. 14.

${ }_{99}$ Recordando-nos novamente o poema "Áporo".
} 
- tudo que sei é que esta flor composta do seu sangue compartilha do pulsar do seu destino. Vamos.

[Resposta do personagem a seu criador, "condenado a viver".]

[Testamento de Orfeu, de Jean Cocteau]

\section{Rosa trismegista aberta ao mundo}

O "Canto órfico" que integra Fazendeiro do ar, assim como "Legado", de Claro enigma, representam, através da maneira como aludem a Orfeu, um contrapasso, ou um compasso diferente do estado de frustração ou de recolhimento definidos por grande parte da crítica drummondiana ao tratarem desses dois livros.

Nos dois poemas, Orfeu aparece como uma possibilidade de tomada de fôlego, o possível "respiro" de uma possível "rosa trismegista aberta ao mundo". Lembrando o paradoxo do título "Claro enigma", "a rosa", símbolo da poesia de Drummond - já presente em sua "Flor e a náusea" e, sobretudo, na Rosa do povo - mesmo vista como hermética, (talvez, ironicamente, Trismegista, ou seja, três vezes hermética) dispõe-se ao mundo, impulsionada pela sugestão do poeta cantor $^{100}$. Pensando sobre a comunicabilidade e o leitor, podemos lembrar de "A flor e a náusea" (Rosa do povo), cujo final assemelha-se à "guinada" poética frente ao mundo indiferente ${ }^{101}$ esboçada no "Canto órfico" e nos outros poemas citados acima:

[...] Em vão me tento explicar, os muros são surdos.

Sob a pele das palavras há cifras e códigos

\footnotetext{
${ }^{100}$ É interessante lembrar que Hermes é o deus que recebe os mortos no Inferno, que Ihes indica o caminho, o que traz novamente para o poema a relação entre vida e a encruzilhada em que os destinos são forjados.

${ }^{101}$ Cf.: Candido, Antonio. Vários escritos.Op.cit.p. 124. Em "A flor e a náusea" "O ideal surge como força de redenção e, sob a forma tradicional de uma flor, rompe as camadas que aprisionam. Apesar da distorção do ser, dos obstáculos do mundo, da incomunicabilidade, a poesia se arremessa para frente numa conquista, confundida na mesma metáfora que a revolução."
} 
O sol consola os doentes e não os renova.

As coisas. Que tristes são as coisas, consideradas sem ênfase. [...]

E dou a poucos uma esperança mínima.

Uma flor nasceu na rua! [...]

É feia. Mas é uma flor. Furou o tédio, o nojo e o ódio ${ }^{102}$.

Toda a primeira parte do "Canto órfico" é desabafo acusatório contra o mundo, mas o elenco de perdas apontadas, pela forma como se apresenta, pode ser tomado também como confissão de culpa por aquela desintegração e imporosidade que impedem a visão da luz, onde "talvez" esteja a essência perdida. A procura inquiridora pela "tua medida", pela "tua cifra" e a revolta contra a paralisia do mundo podem transfigurar um mea culpa de quem acusa, que se repete a cada início de estrofe e continua em eco pelas outras oclusivas ("t"). $\mathrm{Na}$ reiterada acusação-testemunho, os termos de introspecção transfiguram a atitude deste que é capaz de, percebendo as "faltas", mergulhar em seu próprio "abismo" e transformar o que era negativo em possibilidade de mudança. $O$ mea culpa retomado em toque interno repetido, "retumbando em nós", é então o fôlego de um novo ritmo figurado por Orfeu.

O tom acusatório do "Canto órfico", observado também como confissão de culpa, encaixava-se ao que Paul Diel revelava sobre o simbolismo na mitologia grega, visto como expressão dos próprios conflitos internos do homem; a questão ética observada no comportamento psíquico humano parece estar também no poema, no conflito expresso pelo poeta entre ele e o mundo.

Depois de sua descida ao Inferno, Orfeu volta transformado; depois desta experiência, ele passa a reconhecer o valor da memória e de seu comportamento no mundo, como possibilidade de, depois da morte, atingir um outro plano, junto aos deuses, conforme começou a propagar com o Orfismo. Para os órficos, não 102 Op. cit., p. 78. 
lembrar as palavras corretas a serem ditas depois da morte, no reino de Hades, e o caminho a ser escolhido resultaria na perda da possibilidade de convívio com os deuses e na volta, em outro corpo, ao mundo terrestre, tido como passagem de sofrimento expiatório.

A vida na terra tida como expiação pelos órficos aparece também no "Canto órfico". Mas o retorno à terra, diferentemente do que divulgava o Orfismo, é considerado como uma espécie de nova oportunidade.

Em "Canto órfico", o voltar-se para si mesmo associado à referência a abismo sugere a imagem da morte, a passagem por ela, que resulta também em um renascimento em outro corpo e em uma nova maneira de agir no mundo, mas sem desconsiderar a existência desse. Diferentemente do que propunham os órficos, não se almeja, também no "Canto órfico", como em "Legado" o convívio com os deuses. O pedido para que Orfeu "desça ao nosso tempo" é significativo, pois considera a perda como fato, como se o poeta apontasse a necessidade da experiência de Orfeu, da sua descida ao inferno, que resulta numa mudança pessoal.

No poema, este novo corpo, depois da descida ao Inferno, do mergulho abismal em si mesmo, enfrenta o mundo de outra forma; como vimos, não é o mundo que muda, mas o poeta frente a este mundo. Essa espécie de volta em outro corpo (mesmo que entendida como uma situação conflituosa) é tida como respiro, como inspiração de vida dentro da poesia, movida pela presença, mesmo que por alusão, de Orfeu e sua experiência.

Se, por um lado, a primeira parte do poema superficialmente apresenta uma visão pessimista em relação à vida, próxima à visão de Schopenhauer, na segunda parte, parece emergir o "otimismo heróico" de Nietzsche; como se a "vontade de viver" anterior - o Orfeu subsumido -, despontasse como "vontade de poder" criadora ${ }^{103}$.

\footnotetext{
${ }^{103}$ Esta relação entre os conceitos dos dois filósofos aplicada ao poema de Drummond derivou, além de outras leituras sobre Shopenhauer e Nietzsche, das observações de Anatol Rosenfeld em "Influências estéticas de Shopenhauer". In Texto e contexto. $3^{\circ}$ ed. São Paulo: Perspectiva, 1976.
} 
Mas se no "novo corpo" pressentimos algum tom de resignação contemplativa shopenhaueriana ${ }^{104}$, o chamado por Orfeu feito pelo poeta frente ao que ele vê (ou não vê), no mundo, sugere o desejo de uma resolução mesmo que ideal, no mundo real, vinda pelo canto. Nessa referência, Drummond aproxima-se tanto de Nietzsche, pelo tom afirmativo em relação à vida, quanto do próprio Schopenhauer ${ }^{105}$, pela constatação do potencial da música. Em outros termos, o canto órfico parece ser considerado pelo poeta como uma fresta, uma possibilidade de compreensão imediata dos conflitos humanos, em si mesmo esclarecedora.

\section{$A$ alusão a Orfeu}

Canto e poesia estão relacionados desde sua origem, e nessa origem encontramos Orfeu. Evocar seu mito é reconfirmar o valor permanente do canto que, se já não encanta os monstros atuais, também não deixa de querer encantálos, como os outros poetas e artistas relembrados ${ }^{106}$ por Drummond, que, como Orfeu, continuam ecoando mesmo após a morte, desvelando o mundo, pois, tomando as palavras de José Guilherme Merquior sobre Drummond: "[...] nem a demolição da existência, nem o caos do universo, nem as derrotas do eu e da existência roubam o que quer que seja à dignidade do exercício inalienável da lucidez existencial. Para Drummond, se a ordem do mundo se desqualifica, o sentido da individualidade moral é em conseqüência, reforçado."107

\footnotetext{
${ }^{104}$ Segundo Schopenhauer, a arte é o único meio pelo qual o homem pode libertar-se, ainda que provisoriamente, do sofrimento da vida terrena.

105 "Ao passo que todas as outras artes reproduzem apenas idéias platônicas, sendo portanto, somente representações mediatas da vontade, a música exprime de modo imediato o próprio ser do mundo. As outras artes 'falam só da sombra, ela porém, da essência', chegando a ser por isso um 'exercício metafísico'." Cf.: Anatol Rosenfeld. Op. cit., p. 180.

${ }_{106}^{100}$ Aos quais não se pode deixar de acrescentar Charles Chaplin.

${ }^{107}$ Merquior, José Guilherme. Op. cit., p.142.
} 
Na atualização que Drummond faz de Orfeu, em "Legado", ele próprio como poeta se identifica a um Orfeu gauche que se opõe ao Mundo de valores fugazes, obstáculo para a transmissão do legado desejado pelo poeta. Ou seja, Orfeu não se realiza em plenitude, seu canto não consegue transformar o Mundo na dimensão em que o poeta deseja. Seu canto/poema fica (toda a obra de Drummond é prova disto), mas como resistência ${ }^{108}$, o que não deixa de ser uma vitória sobre a passagem do tempo, sobre a morte. Em "Canto órfico", novamente Drummond se identifica a Orfeu, agora dividido, à procura da unidade perdida.

Drummond não via lugar para os mitos em nossa época, mas certamente sabia da necessidade de evocá-los, de fazer alusão a Orfeu, afinal, é principalmente quando percebemos as faltas que damos a tudo o que deixou de estar perto de nós o seu real significado. A negação é sempre de algo que já existiu, ela não instaura a existência, nos faz lembrar dela, mesmo como uma impressão de vazio.

No percurso desse canto órfico percebemos o valor desse canto singular; parece ser este o caminho a que nos leva o poeta: a percepção das faltas e da necessidade de encontrar Orfeu em nós mesmos.

${ }^{108}$ Cf.: Bosi, Alfredo. O ser e o tempo da poesia. São Paulo: Cultrix, 1983. 
CAPÍTULO III

O VIVO ENCONTRO ENTRE O ERUDITO E O POPULAR

Vinícius de Moraes escreveu o primeiro ato de Orfeu da Conceição, no começo da década de 40 e finalizou a peça em meados dos anos 50. Encenada no Teatro Municipal do Rio de Janeiro, com platéia lotada, em 25 de setembro de 1956, com elenco formado apenas por atores negros ${ }^{109}$, contrapunha-se a sua época em que personagens negros chegavam a ser interpretados por atores brancos ${ }^{110}$. A peça de Vinícius repetia o fato ocorrido há mais de quarenta anos, quando $O$ contratador de diamantes, primeira representação exclusivamente feita por negros, estreou no Teatro Municipal de São Paulo, em 1914, tornando-se, em sua época, o acontecimento central na aproximação entre a elite intelectual do começo do século em São Paulo e a cultura popular.

\footnotetext{
${ }^{109}$ Moraes, Vinícius. "A propósito de Orfeu da Conceição". In Orfeu da Conceição. $2^{\circ}$ Ed., Rio de Janeiro: Dois amigos, 1967, p. 13. Apud. Paranhos, Luís Tosta. Rio de Janeiro: José Olympio Editora. 1980

${ }_{110}$ Em A cabana do pai Tomás, por exemplo, Sérgio Cardoso, ator branco, fazia o papel do personagem principal, que era negro.
} 


\title{
1- "O morro é Orfeu", análise e interpretação de Orfeu da Conceição.
}

\author{
Orfeu, pela paixão cruxificado
}

Orfeu da Conceição ${ }^{111}$ vive em uma favela, na capital do Rio de Janeiro. É músico como seu pai, Apolo, que the ensinou "tudo" sobre violão ("da posição à harmonia"), e de Clio que, como muitas moradoras das favelas cariocas, na década de 60, lava roupas para manter a casa. Há sintonia entre o músico e o ambiente onde vive. Integrado à natureza, sua música dialoga com os animais ${ }^{112}$, por outro lado, os ventos e os ruídos da noite prenunciam seu sofrimento ${ }^{113}$.

${ }^{111}$ O nome da peça, Orfeu da Conceição, foi sugerido por João Cabral de Melo que incentivara Vinícius a reescrever o terceiro ato, perdido, e encaminhar a peça ao Concurso de Teatro do $4^{\circ}$ Centenário de São Paulo, em 1953, do qual sairia vencedor. Cf.: Moraes, Vinícius. Orfeu. Op. cit. p. 65.

${ }^{112}$ A relação amistosa entre o poeta, os animais e a natureza é explicitada em várias rubricas, como nesta onde é descrito o desafio entre sons produzidos pelo violão de Orfeu, vozes dos animais e a trepidação das folhas: "Orfeu: — Toda a música é minha, eu sou Orfeu".

(Dá uma série de acordes e glissandos à medida que se aproxima da amurada. Vindas ninguém sabe de onde, entram voando pombas brancas que logo se perdem na noite. Próximo uivam cães longamente. Um gato que surge vem esfregar-se nas pernas do músico. Vozes de animais e trepidações de folhas, como ao vento, vencem por um momento a melodia em pianíssimo que brota do violão mágico; Orfeu escuta extático. Depois recomeça a tocar, enquanto por sua vez, cessam os sons da natureza. Ficam nesse desafio por algum tempo alternando vozes, até que tudo estanca, vozes ruído e música.)"[p.403]

A unidade entre Orfeu e a natureza é expressa também no diálogo entre Clio e Apolo, ao ouvirem a música de Orfeu:

"Apolo: - Toca muito este meu filho, até parece/Não um homem, mas voz da natureza .../Se uma estrela falasse assim dizia/[...] Esse menino/Eu pensava, conversa com as estrelas.../Vai ver conversa mesmo". [p.402]

${ }^{113} \mathrm{O}$ vento expressa os perigos da paixão por Eurídice:

"([...] Eurídice reponta pungente em seu dedilhado agônico [...] Uma lufada de vento traz sons como de uma harpa, que parecem enunciar o nome de Eurídice [...] [p.408, grifos meus]; (Beijamse num embate irresistível, enquanto novamente o céu escurece, como se uma nuvem ocultasse a Lua. Sons como vozes informes parecem vir do vento em meio aos quais repontam subitamente os gemidos agoniados de Euńdice.) [p.411, grifos meus]; [...] De repente retorna o vento, e os rumores estranhos da noite. O violão toca agitado por alguns instantes enquanto Eurídice se afasta.) [p.412, grifos meus]". Na primeira despedida do casal, antes de Mira fomentar o ciúme e inveja de Aristeu, a rubrica novamente aproxima "vento" /"perigo" e "paixão": "(Orfeu prende-a num beijo e os dois amorosos se enlaçam estreitamente, enquanto volta o vento e com o vento os sons misteriosos da noite. Mas eles não percebem, entregues à força da paixão.)" [p.422, grifos meus]. 
$\mathrm{Na}$ peça, ressaltam-se as características de guia e vidente ${ }^{114}$ próprias do mito de Orfeu, habilidade e dom que também em Orfeu da Conceição são inatos. Além disso, Orfeu é deificado. Aproximações entre ele e Cristo perpassam a peça agregando mais este registro comum também ao cantor trácio ${ }^{115}$.

No soneto de abertura da peça, essa aproximação já se insinua na sentença do Corifeu: "São demais os perigos dessa vida, para quem tem paixão" ${ }^{116}$. Nas rubricas, há referência ao tocar "divino" do violão que plange a valsa de Eurídice [p.401]; Orfeu "ri beatificamente, balançando a cabeça" [p.403]. As reiteradas observações dos personagens tornam a confluência ainda mais evidente. Ela está na ordem de Clio a Apolo, no momento em que ouvem o canto de Orfeu :

- Mas fica quieto peste. É até pecado

Ficar falando com Orfeu tocando. [grifo meu, p.403];

na observação de Apolo:

- Escuta só (dá risada) Até ofende a Deus

Tocar dessa maneira. Olha que acordes

Tanta simplicidade [...] [grifo meu, p.402];

nos comentários dos moradores, em que as palavras "santo" e "anjo" são associadas ao músico, e, de forma mais explícita, quando o coro, portador nas tragédias da "voz do povo", rezando o Credo, substitui o nome de Cristo pelo de Orfeu, confirmando a deificação do músico:

Coro

\footnotetext{
114 Orfeu tem a impressão de ver Eurídice morta, antecipando o que de fato acontecerá: “- $\mathrm{Ai}$, que agonia que você me deu/ Meu amor! que impressão, que pesadelo!/Como se eu te estivesse vendo morta/ Longe como uma morta..." [p. 413]

${ }^{115}$ No primeiro séc. da era cristã, a figura de Orfeu, representando veladamente Cristo, teria sido usada pelos cristãos que temiam ser perseguidos. Alguns estudiosos afirmam ainda que o Orfismo, de certa forma, anunciaria o monoteísmo instaurado depois pelo Cristianismo.

${ }^{116}$ Ampliando ainda mais o contexto do soneto, podemos dizer que este alerta do Corifeu diz respeito aos poetas e artistas em geral que, de certa forma, submetendo-se às dores de outros, dão voz a suas criações.
} 
Quinta voz :

- Creio em Orfeu ... ["Creio em Deus, pai todo poderoso"]

Sexta voz :

- Criador da melodia ... ["Criador do céu e da terra"]

Primeira voz :

- Orfeu filho de Apolo ... ["e em Jesus Cristo, seu único filho"]

Segunda voz :

- Nosso Orfeu ... [“Nosso Senhor"]

Terceira voz :

- Nasceu de Clio ... ["nasceu da Virgem Maria"]

Quarta voz :

- E muito padeceu ["padeceu sob o poder de Pôncio Pilatos"]

Sob o poder maior da poesia

Quinta :

- E foi pela paixão crucificado ... ["foi crucificado, morto sepultado"]

Sexta voz :

- E ficou louco abandonado ...

Coro (em uníssono) :

- Desceu às trevas, e das grandes trevas ressurgiu à luz, e subiu ao morro onde está vagando como alma penada procurando Eurídice ... ["desceu a mansão dos mortos, ressuscitou ao terceiro dia, subiu aos céus, está sentado à direita de Deus, pai todo poderoso, de onde há de vir para julgar os vivos e os mortos ..."]

Até mesmo a revolta de Clio contra Deus insinua esse caráter divino do músico:

- Deus ...(muda de tom) Não quero mais saber de Deus!

Que Deus é esse que apagou assim

O espírito de Orfeu? Não quero Deus!

Deus é mentira, Deus de inveja, Deus... [grifo meu, p.439] 
A descida até o clube dos "Maiorais do Inferno", em busca de Eurídice, não só retoma o mito, mas também reforça a aproximação entre Orfeu e Cristo, que desceu à "mansão dos mortos".

\section{A descida de Orfeu ao clube "Os Maiorais do Inferno"}

Orfeu desce do morro e vai até o clube "Os maiorais do Inferno" querendo ver Eurídice "nem que seja pela última vez". É "fim de baile de terça-feira gorda", último dia do Carnaval. Plutão comanda a festa; ao seu lado está Proserpina. A ordem a todos é aproveitar a festa, pois "amanhã não tem mais". Todos estão bastante bêbados.

A batucada vai atingindo "proporções fabulosas, enquanto todo o mundo se põe a dançar, batendo com os pés a marcação". O som ao longe do violão de "em escalas dulcíssimas, em trêmulos e glissandos" vai aos poucos vencendo o som estrondoso. Assim, Orfeu "domina o Cerbero" e entra no clube. Indiferente à sua dor e vendo nele uma ameaça ao seu baile, Plutão insiste imperativamente para que a festa continue: "Não acabou o Carnaval ainda".

Contraste é a expressão-síntese deste ato. A música continua revelando os sentimentos de Orfeu, mas não representa neste momento a integração lúdica entre o músico e seu meio (dos animais, plantas e vento); o "som cristalino" de seu "violão que plange" vai de encontro ao som de "proporções fabulosas" da batucada, expressão da urgência de se aproveitar o dia "porque a morte é certa". No clube, fica clara a oposição entre a alegria exigida por Plutão às pessoas que quase não se sustentam em pé e a tristeza profunda do músico. Neste ato, mais do que as falas, é a expressão dos sons, definida pelas rubricas, que compõe o conflito entre o drama de Orfeu e a atitude impermeável dos que o rodeiam no baile.

No palco, depois de sua saída, a luz ilumina um jogo de capoeira, como um reflexo do embate sofrido por ele. 
Acompanhando a paixão, os presságios de sofrimento e morte perpassam toda a peça. A dor relacionada a este sentimento é uma constante desde as primeiras palavras do Corifeu -, passando pela agonia de Clio, de Apolo ${ }^{117}$ e da própria natureza expressada pelos ventos ${ }^{118}$. O pressentimento sombrio atinge 0 músico que sem conseguir decifrá-lo reclama para si mesmo, quanto está só:

\author{
- Ô paixão danada! \\ Ô paixão ruim! [...] \\ -Não é nem mais bem querer ... é coisa ruim \\ morte! [p.423]
}

A cena acontece depois de Orfeu discutir com Mira de Tal e esta instigar Aristeu a matar Eurídice, momentos antes do aparecimento amedrontador da Dama Negra, confirmando o temor do músico ${ }^{119}$.

Ao sentimento antagônico da paixão, de exultação e temor, corresponde o jogo entre luz e escuridão, simultâneo aos movimentos correspondentes da natureza e dos animais. ${ }^{120}$ Em cena, reafirmando a oposição de forças em Orfeu,

\footnotetext{
${ }_{117}$ Meu Deus que coisa horrível!//Por que é que nesse mundo não tem paz?//Por que tanta paixão? [p.441]

${ }_{118}$ ([...] Eurídice reponta pungente em seu dedilhado agônico [...] Uma lufada de vento traz sons como de uma harpa, que parecem enunciar o nome de Eurídice [...] Tudo é Eurídice [...] e a presença da mulher amada deve manter-se com uma força e fatalidade inenarráveis.) [p.408, grifos meus] /Orfeu (abraçando-a violentamente)-Paixão, paixão, paixão/ paixão por ti mulher!//(Beijamse num embate irresistível, enquanto novamente o céu escurece, como se uma lua ocultasse a Lua. Sons como vozes informes parecem vir do vento em meio aos quais repontam subitamente os gemidos agoniados de Eurídice.) [p.411, grifos meus] $/$...] De repente retorna o vento, e os rumores estranhos da noite. O violão toca agitado por alguns instantes enquanto Eurídice se afasta.) [p.412, grifos meus]

${ }^{11}$ Na primeira despedida do casal, antes de Mira fomentar o ciúme e a inveja de Aristeu, a rubrica novamente aproxima vento, "perigo" e "paixão": "(Orfeu prende-a num beijo e os dois amorosos se enlaçam estreitamente, enquanto volta o vento e com o vento os sons misteriosos da noite. Mas eles não percebem, entregues à força da paixão.)" [p.422, grifos meus].

${ }^{120}$ Depois do soneto que prenuncia os "perigos", a "noite faz-se subitamente escura, como se uma nuvem espessa tivesse encoberto a Lua" [p.403]; a cena escurece, pouco antes de Aristeu (o assassino de Eurídice) aparecer pela primeira vez [p.418]; "tudo escurece novamente" pouco antes de a Dama Negra anunciar a morte [p.419]; "a cena vai escurecendo lentamente, enquanto a Dama Negra surge[...]", logo depois da morte de Eurídice. Por outro lado, Orfeu reaparece, "ao clarear a cena", "no topo da escada, o violão a tiracolo", após o primeiro escurecimento de cena; "a lua ilumina a cena" quando Orfeu chega "acompanhando no violão um choro que se executa no morro" (logo depois de Mira instigar Aristeu contra o casal apaixonado); "uma luz branca projeta-se
} 
o músico é identificado à luz branca, ao passo que a escuridão anuncia os perigos imediatos pelos quais passará.

$\mathrm{Na}$ assertiva do Corifeu :"são demais os perigos desta vida/ para quem tem paixão" - que abre o espetáculo em soneto, de caráter genérico ${ }^{121}$, mas que antecipa a futura tragédia de Orfeu da Conceição - o sofrimento do qual se padece é representado pela "mulher" que é feita de "música, luar e sentimento".

A morte, figurada por uma mulher (a Dama Negra), amedronta Orfeu e desaparece no mesmo momento em que Eurídice, plenitude de sua vida, aparece, no mesmo lugar, vestida da mesma forma, carregando as mesmas flores. Assim, ao mesmo tempo em que se antecipa o desfecho trágico da peça, as imagens sobrepostas - da "morte" e de Eurídice - reafirmam a proximidade, cruel, entre amor e dor, a ser vivenciada pelo músico, confirmando todos os presságios anteriores: os seus, os da natureza, do Corifeu e das pessoas próximas ao músico.

A morte da mulher pela qual Orfeu se apaixona enlouquece-o. Ele é "pela paixão crucificado". Mas finalizando a peça, depois de o cantor ser estraçalhado pelas mulheres, "uma música trêmula [que vem de seu violão] incute, misteriosa e incerta". Como conclui o coro:

\footnotetext{
Juntaram-se a Mulher, a Morte a Lua

Para matar Orfeu, com tanta sorte

Que mataram Orfeu, a alma da rua

Orfeu o generoso, Orfeu o forte.

Porém as três não sabem de uma coisa:

Para matar Orfeu não basta a Morte.

Tudo morre que nasce e que viveu

Só não morre no mundo a voz de Orfeu.
}

sobre a porta de entrada" do clube dos "Maiorais do Inferno", quando Orfeu surge.

121 "São demais os perigos desta vida/ Para quem tem paixão, principalmente/ Quando uma lua
surge de repente/ E se deixa no céu, como esquecida.// E se ao luar que atua desvairado/Vem se
unir uma música qualquer/ Aí então é preciso ter cuidado/ Porque deve andar perto uma mulher.//
Deve andar perto uma mulher que é feita/ De música luar e sentimento/ E que a vida não quer de
tão perfeita...// Uma mulher que é como a própria Lua:/ Tão linda que só espalha sofrimento/ Tão
cheia de pudor que vive nua." [p.402] 
Apaixonado, Orfeu é submetido ao sofrimento, cujas causas estão fora dele, mas que o iluminam, ao mesmo tempo ${ }^{122}$.

\section{A tragédia de Orfeu da Conceição}

O sofrimento de Orfeu, que marca o caráter trágico da peça, é a consciência de seu limite. Apesar de integrado à natureza, graças ao poder de seu canto - "Orfeu é o morro", exclamava o músico -, ele sofre por não vencer a morte, como acreditada poder; por não vencer o que era sugerido pelos repetidos presságios. Diferentemente do que ocorre com o Orfeu grego, não é representado na peça, como ação, o seu erro, ou seja, a desobediência a qualquer condição que Ihe trouxesse Eurídice de volta: o não olhar para trás. A alternativa de reverter a tragédia, a possibilidade de ter a amada de volta a depender de uma atitude sua, não aparece na peça de Vinícius de Moraes.

Para Paul Diel, a desobediência de Orfeu à condição imposta por Hades, para que recupere Eurídice, representa a indecisão do cantor entre 0 desbordamento dionisíaco anterior ao amor por Eurídice e a devoção exclusiva a ela. A atitude de olhar para trás, de denegar a condição imposta, simboliza a indecisão entre os desejos materiais e espirituais, entre a insaciabilidade apaixonada dionisíaca e a harmonia ideal apolínea.

Como infere o psicólogo :

\footnotetext{
${ }^{122}$ Apenas uma lembrança: no norte de Minas Gerais, uma mulher que habitava uma lapa me contava, sem explicar, a morte da filha naquele mesmo lugar. Falava de bebida, de álcool; confundia outras lembranças e também falava de incêndio; tinha ficado apaixonada desde aquele dia... era uma tristeza só enquanto segurava meu braço, com olhar iluminado. Inesquecível. Conversando com quem acompanhara comigo aquela vontade de repetir e repetir a mesma história, percebemos o novo, ou talvez o mais antigo significado do termo paixão e de ficar apaixonado. Ela entrecortava a narração, tinha ficado apaixonada, e voltava a repetir a história da filha e a mesma palavra, talvez assim como Orfeu, chamando Eurídice, querendo vê-la nem que fosse por apenas mais uma vez.
} 
Somente o sentimento verdadeiro e profundo, o amor por Eurídice, poderia salvar Orfeu. $\mathrm{O}$ mito de Eurídice é na verdade a história do estado de alma de Orfeu. Eurídice é o lado sublime dele, sua força de concentração apolínea. A morte dela simboliza o desaparecimento da força sublime: significa a morte da alma de Orfeu, sua banalização. ${ }^{123}$ [grifo meu]

Mas, observa ainda Paul Diel, diferentemente do transbordamento dionisíaco de desejos, o final do mito grego revela um outro aspecto bastante revelador: o sentimento de culpa pela perda definitiva de Eurídice, causado pela falta de domínio sobre si mesmo, leva o músico a um desinteresse completo pelos prazeres perversos e à devoção a Apolo, o que teria levado as bacantes (mênades) dionisíacas a estraçalharem-no. Assim, a desmedida não seria mais a do músico, mas a do mundo a sua volta. De acordo com o psicólogo:

Depois de ter provocado a morte definitiva de Eurídice, símbolo do amor exclusivo, Orfeu, horrorizado com o remorso pelos prazeres perversos que o ligaram à libertinagem, teria conseguido reanimar Eurídice, símbolo de sua aspiração sublime. Controlando sua insaciabilidade banal, ele teria transformado-a em intensidade criadora, libertando-se de sua indecisão dilaceradora. Orfeu teria assim encontrado toda a força do amor sublime, sob a mais alta forma de objetivação: não mais o amor da mulher inspiradora, mas o amor pela harmonia, direção legal da vida e da arte, simbolizada pelo deus-inspirador, Apolo. Por conseguinte, as mênades [bacantes], não significam mais, dentro desta versão, o despedaçamento interior do herói, mas a exaltação dos desejos que reina no mundo. Elas guardam a significação da perversão desencadeada e sua culpa latente, que ultrajada pela vitória essencial, transforma-se em agressão vingadora. [...]. ${ }^{124}$

Orfeu da Conceição não é submetido à prova, a ele não é oferecida nenhuma chance de reencontrar sua amada. A cena mais próxima disso acontece quando olhando para Eurídice - sem sentimento de culpa ou desejo de perdão ele pede para que ela fique. Na cena seguinte, como sabemos, Aristeu, instigado por Mira de Tal, assassina a moça. A opção deste Orfeu não é pelo seu passado, como ocorre com o mito grego, segundo a interpretação de Paul Diel, mas por Eurídice. Nos últimos momentos em que estão juntos, aliás, parece haver uma

\footnotetext{
${ }^{123}$ Op. cit., p. 137

124 Op.cit.: p.141.
} 
mudança dos dois, acompanhada também pela ação da natureza ao redor deles. Ao invés da agonia dos ventos ou noite escura - índices negativos, que sombreiam a paixão dos dois -, a "noite se faz imensamente clara e pássaros noturnos chilreiam invisíveis, enquanto melodias parecem vir da voz do vento" quando os dois "beijam-se de novo, ternamente, e entram juntos no barraco" transformando a "agonia", com a qual Orfeu se despedira de Eurídice em cena anterior $^{125}$-, como se a paixão noturna se transformasse em luz harmônica matinal e apolínea, não expressando mais a desmedida; como se a atitude de Orfeu, na cena anterior chamando Eurídice, expressasse não a sua renúncia a ela, mas o cuidado em não a perder jamais . ${ }^{126}$

As discussões com Mira e Clio por causa de Eurídice também frisam a opção de Orfeu. O contraponto entre a vida desmedida, anterior à Eurídice, e a opção por ela é exposto já no início da peça, quando Clio usa como argumento contra o casamento de seu filho com Eurídice o interesse de todas as mulheres do morro por ele. Tentando ainda convencer sua mãe sobre o momento singular em que vive, Orfeu usa a terceira pessoa do singular (como faz quando tenta afastar a Dama Negra: "O morro é Orfeu"), e assim, ao mesmo tempo em que comprova sua negação à desmedida anterior, afirma sua escolha pelo sublime, ao que chega por meio de suas canções:

\footnotetext{
Você não entende, não; não sou mais eu

É ela, minha mãe .... Orfeu é Eurídice

A música de Orfeu é como o vento

E a flor; sem a flor não há perfume

Há o vento sozinho, e é triste o vento

Sozinho, minha mãe.
}

\footnotetext{
125 “Querida/ Não vai não”, p.413.

126 Além disso, as discussões com Mira e Clio por causa de Eurídice também parecem frisar a opção de Orfeu.
} 
Logo no início da peça, o Corifeu anuncia o sofrimento de Orfeu, submetido "aos perigos dessa vida", sinalizando a sua imersão no mundo, mas diferentemente do Orfeu grego, nesta imersão, Orfeu da Conceição opta sinceramente pelo amor de Eurídice, motor do toque sublime de seu canto que filtra a desmedida do mundo; não no sentido de uma purificação da vida cotidiana, mas como uma harmonização em que a inteligibilidade e a emoção, ou seja, as forças apolíneas e dionisíacas entram em conjunção.

O sentimento de culpa, portanto, se existe na peça, não parece derivar de uma indecisão de Orfeu entre o "desejo sublime" e os "desejos múltiplos e perversos"127 (marcados no mito pelo "olhar para trás"), mas da consciência torturante da limitação de seu canto, da sua incapacidade de reverter a dor definitiva, a consciência da impossibilidade de seu canto, mesmo sendo capaz de transformar os animais e de conversar com a natureza, não vencer a efetivação dos seus presságios, não impedir a morte de sua amada.

${ }^{127}$ Diel, Paul. Op.cit., p. 137-8. 
Orfeu da Conceição : A Aretê do poeta e cantor do morro carioca

A integração entre Orfeu e o morro é expressa por ele como força com a qual ele acredita dominar até mesmo a morte. $O$ uso da terceira pessoa do singular, quando se confronta com a Dama Negra, sugere o reconhecimento público de seu poder forjando sua crença no valor desta unidade:

- Vá embora

Senhora Dama! eu the digo

No morro manda Orfeu! Orfeu é a vida

No morro ninguém morre antes da hora!

Agora o morro é vida, o morro é Orfeu

É a música de Orfeu! Nada no morro

Existe sem Orfeu e a sua viola!

Cada homem e sua mulher

Vivem só porque Orfeu os faz viver

Com sua música! Eu sou a harmonia

E a paz e o castigo

O músico! [p.421, grifos meus]

A lua ilumina o músico, sobretudo nos momentos de ternura ao lado de Eurídice. Os ventos e outros ruídos da noite prenunciam o sofrimento pelo qual passará. Sua música dialoga com os animais. Orfeu com seu canto está integrado à natureza, que é extensão do que sente e do que é pressentido e revelado por ele pelos diferentes sons de seu violão, ora tristes, ora enraivecidos, apaixonados, serenos, agoniados ou mesmo debochados. "O morro é Orfeu".

Para ele, perdão e culpa, identificados ao catolicismo e às outras religiões que consideram a vida como pagamento dos pecados cometidos, não têm lugar no contexto apaixonado vivido com Eurídice. Isso fica expresso na sua inferência, feita depois de abraçá-la violentamente, num arroubo de paixão. Não há uma 
oposição ao "que Deus quer". Certamente a intervenção é a de alguém apaixonado, mas ela também o aproxima do homem grego clássico, cujo sentimento ético, a aretê grega, não está fora, mas nele mesmo. Sua primeira ação, apaixonada, lembra Dionísio; a segunda, esclarecedora, lembra Apolo, as duas influências maiores sobre o Orfeu grego:

Eurídice

Ainda não!

Por favor, meu amor, um segundinho/

Só; daqui dois dias nos casamos/ [...]

vamos fazer assim como Deus quer

Não é mesmo? [p.410]

Orfeu (abraçando-a violentamente)

Paixão, paixão, paixão

Paixão por ti, mulher!

(Beijam-se num embate irresistível, enquanto novamente o céu escurece como se uma nuvem ocultasse a Lua. Sons como vozes informes parecem vir do vento, em meio dos quais repontam subitamente os gemidos agoniados de Eurídice.)

Eurídice (a voz embargada)

Não meu neguinho. Pelo amor de Deus

Ainda não! ainda não!

Orfeu

Perdão, Eurídice

Se é que é possível o amor pedir perdão. [...]

Eurídice

Desculpa

A culpa é minha, eu sei ...

Orfeu

Ninguém tem culpa

Minha neguinha ...é só amor - mais nada ... [grifos meus, p.441] 
Ele sabe o poder que tem; em seu diálogo com a Dama Negra isso está claro: "O morro é Orfeu", ele é "a vida", "a harmonia"; mas este poder não envolve disputa, nem Orfeu parece se colocar como Deus. Ele não é o criador do morro, mas "o nosso Orfeu" - como "rezam" os moradores do morro -, "criador da melodia". Esta atitude o aproxima do mito grego: diferentemente do que ocorre com a grande maioria dos heróis, sempre envolvidos em grandes conflitos por poder, não há nele desejo de disputa. Orfeu é "igual ao morro". Identificar-se ao lugar onde vive antes o aproxima da aretê grega, da unidade, hoje ideal, entre o homem e o mundo, sem mediação : a voz da comunidade, enquanto identificada à natureza, e a voz de Orfeu são uma só.

O exemplo maior dessa unidade está na transformação do morro: alegria e harmonia, simultâneas aos momentos em que o músico está feliz, transformamse, dando lugar a desentendimentos e problemas sociais, quando Orfeu enlouquece, por causa da perda definitiva de Eurídice:

Um velho (balançando a cabeça) [...]

- Com Orfeu esse morro era outra coisa.

Havia paz. A música de Orfeu

Tinha um poder a bem dizer divino...

A terceira mulher

- É. Não tá certo.

Desandou tudo nesse morro. Tudo.

Quanta briga, meu Deus, que tem saído

Quanta gente mudando pra outros morros

Foi mau olhado, foi ... [...]

Um outro homem

- Eu que o diga!

Foi Orfeu quem mudou minha vida

Devo o que sou a ele. Antigamente 
Era só valentia, briga à toa

Té que ele veio e conversou comigo.

Orfeu era um anjo...

Agora digam: vale a pena? ...Qual!

Mulher é perdição ... [...]

Uma outra mulher

- E não faltava nada pra ninguém.

Qualquer necessidade, não sei como

Orfeu sabia e logo aparecia

Um dinheirinho - tudo samba dele ...

Uma tristeza em casa? uma quinz'lia?

Ele vinha, mexia, se virava

Sapecava um sambinha de improviso

Brincava... um anjo! Tinha pés de santo ... [p. 440-1, grifos meus ]

Os sons e ruídos da natureza somem junto à voz do músico; tomam o seu lugar a sirene da ambulância e os comentários, transcritos abaixo, sobre os problemas sociais do morro, anteriormente apenas sugeridos em algumas falas de Clio, mas ignorados pela cidade:

Uma Terceira Mulher:

- É, é preciso

chamar um médico ...

Um Segundo Homem:

- É , tem cada uma ...

médico aqui no morro...

(Dirige-se em tom zombeteiro a um outro homem.)

- Eh, você...

Pega no Cadilac e chama o médico.

O Outro homem (sério):

- Acho-te uma gracinha... 
O Segundo Homem

- Uai, por quê?

Foi a mulher que mandou...

A Mulher:

- Deus me defenda!

Nem se respeita a dor alheia.

Quando Orfeu tava bom não era assim

Esse morro era feliz

Um velho (balançando a cabeça):

- Ah, isso era!

Com Orfeu esse morro era outra coisa.

Havia paz. A música de Orfeu

Tinha um poder a bem dizer divino... [p.441, grifos meus] [...]

O Homem:

- Tá pronto, minha gente!

Trouxe a maca. A ambulância está embaixo

Que cara mais folgado ...Adivinha

O que disse o doutor? ..."- Vocês são fortes

Subam e tragam a mulher que eu espero em baixo

E depressa que eu tenho um caso urgente

me esperando..." [p.444, grifos meus]

\section{As canções de Orfeu}

Na peça, evidencia-se o poder da música capaz de expressar o estado de espírito do poeta ${ }^{128}$, de prever as agruras iminentes ${ }^{129}$ e de afastar (mesmo que

\footnotetext{
128 "Ao emudecer sua mãe, o músico põe-se a tocar baixinho, em acordes nervosos" [p.405]. Ao ver sua mãe chorando "Seu violão como perdido, responde ao estado de alma que o toma em acordes lancinantemente dissonantes."[p.408]; depois da briga com Mira "Pega violão e põe-se a tocar agitadamente. Depois vai serenando, que aos poucos se vão fazendo mais e mais alegres". [p.417]
} 
momentaneamente) os perigos e obstáculos à sua frente, como ocorre na cena em que a Dama Negra anuncia a morte ${ }^{130}$, e em que o Cérbero tenta impedir a busca por Eurídice ${ }^{131}$.

O canto de Orfeu é expressão imediata e natural do que é vivenciado por ele ${ }^{132}$ : a primeira canção, "Um nome de mulher"133, que "brota de seu instrumento", composta após discutir com a mãe que insiste em convencê-lo a não se casar, a não mudar seu modo de vida, fala da subjugação do homem provocada pelo encontro do amor. A segunda canção, "Se todos fossem iguais a você"134, cuja letra "se forma naturalmente, ao sabor do ensaio", nasce depois de Orfeu despedir-se da amada. A terceira, "Mulher, sempre mulher"135, "reponta" depois do confronto com Mira de Tal, sua ex-namorada, e expressa em tom debochado - já distanciado da tensão que a origina -, a insistência de uma mulher frente a um relacionamento que não existe mais.

A terceira canção descreve um momento concreto, mais factual, sem um envolvimento maior de Orfeu, enquanto as duas outras, mais conclusivas, sublinham abstrações do que é vivenciado pelo poeta, sobretudo a segunda, "Se

129 ([...] Seu violão, como que perdido, responde ao estado de alma que o toma em acordes lancinantes dissonantes. A frase musical correspondente ao nome de Eurídice reponta pungente ao seu dedilhado agônico [...]) [p.408]

130 "(Os sons, à medida que se avolumam, vão criando uma impressão formidável de magia negra, de macumba e de bruxedo.) [...] a Dama Negra, ao ritmo que se desenvolve cada vez mais rapidamente, põe-se a dançar passos de macumba, a princípio lenta, depois vertiginosamente, na progressão da música)" [p.432].

131 "Pouco a pouco a música de Orfeu domina o Cérbero, que acaba por vir estirar-se a seus pés, apaziguado"

${ }_{132}$ Três das rubricas que orientam o momento de criação das canções de Orfeu ressaltam a unidade entre o dedilhado ao violão e as palavras de Orfeu, sugerindo o nascimento dessas canções como que por contágio entre letra e música. É interessante, a título de informação, saber do registro de uma das canções de Chico Buarque, gravada por acaso, num intervalo de almoço, quando este outro músico, também sozinho, dedilhava gratuitamente o seu violão. [informação dada em aula pelo prof. Luís Tatit, segundo semestre de 1994, na Faculdade de Letras, da USP]

${ }_{133}$ "Um nome de mulher/Um nome e nada mais.../E um homem que se preza/em prantos se desfaz/E faz o que não quer/ $E$ perde a paz./Eu por exemplo não sabia, ai,ai/ O que era amar/ Depois você me apareceu/E lá fui eu/E ainda vou mais..." [p.408]

134 "Vai tua vida/Teu caminho é de paz e amor/A tua vida/ É uma linda canção de amor/Abre teus olhos e canta a última esperança/ e esperança divina/ De amar em paz.../Se todos fossem iguais a você/Que maravilha viver! Uma canção pelo ar/Uma mulher a cantar/Uma cidade a cantar, a pedir/A beleza de amar../Como o sol, como a flor, como a luz/Amar sem mentir nem sofrer/Existiria a verdade/Verdade que ninguém vê/Se todos fossem no mundo iguais a você." [p.414]

135 "Mulher, ai,ai, mulher/ Sempre mulher dê no que der/Você me xinga/Me bota mandinga/Depois faz a briga/Só pra ver quebrar!/Mulher seja leal/Você bota banca/E infelizmente eu não sou jornal//Mulher, martírio meu/O nosso amor/Deu no que deu/E sendo assim não insista/Vá fazendo a pista/Chore um bocadinho/E se esqueça de mim. [p.417] 
todos fossem iguais a você", que identifica amor, Verdade e natureza.

Essa diferença de conteúdo entre as letras das canções coincide com a relação entre o sujeito e o objeto sobre o que se fala e a duração das notas, observada nos estudos de Luiz Tatit sobre canção. Na terceira canção, "Mulher sempre mulher", existe uma proximidade entre o sujeito e o objeto refletida pelas notas mais curtas que valorizam o ritmo, enquanto nas outras canções, e sobretudo em "Se todos fossem iguais a você", as notas mais longas marcam a distância entre o sujeito e o objeto sobre o qual ele fala (ou canta) ${ }^{136}$. É interessante perceber, nesta canção, a duração ainda maior das notas, justamente no verso que dá nome à música, coincidindo com a expressão do desejo ideal de que a união entre amor, Verdade e natureza, vista pelo sujeito em Eurídice, seja comum a todas as pessoas do mundo; na repetição das estrofes as notas prolongam-se ainda mais, marcando a disjunção entre o poeta e o que ele expressa como desejo, que, se realizado, melhoraria a própria vida (que tanto pode ser entendida como sua vida particular como a vida de todos): "Se todos fossem iguais a você/ Que maravilha viver".

É como se a melodia devolvesse à fala, na canção, o sentimento que a originou, retirando de "Se todos fossem iguais a você", por exemplo, qualquer vestígio de tom hiperbólico ou clichê, que uma leitura sem vigor de melodia pode sugerir.

As canções de Orfeu aparecem com a mesma gratuidade e elaboração observada por Vinícius na favela do Rio. A música "brota" do instrumento de Orfeu [p.408], a melodia "brota" de seu violão mágico" [p.403], sem esforço, mas lá estão o cuidado, a repetição, a obra construída ${ }^{137}$.

\footnotetext{
${ }^{136}$ Um exemplo mais evidente disso temos quando se confronta "Garota de Ipanema", que, penso eu, assemelha-se, quanto à duração das notas e à relação entre sujeito e objeto, à terceira canção da peça ; e "Eu sei que vou te amar", que nestes mesmos aspectos, identifica-se à "Se todos fossem iguais a você". O exemplo do confronto entre "Garota de Ipanema" e "Se todos fossem iguais a você" foi dado em aula pelo prof. José Miguel Wisnik, quando comentava o método de análise de Luiz Tatit.

137 "Orfeu, atento ao chamado, dedilha mais cuidadosamente certas frases. Aos poucos, o samba começa a adquirir forma, enquanto a letra espontânea, a princípio soletrada, vai se adaptando à música"; "O samba se vai pouco a pouco revelando, enquanto a letra se forma naturalmente, ao sabor do ensaio" [p.414] , "[Orfeu] pega no violão e põe-se a tocar agitadamente. Depois vai
} 
Gratuidade e elaboração recuperam traços de Dionísio e Apolo, respectivamente, e voltam tanto no entusiasmo de Orfeu, ao terminar, em cena, sua primeira canção ${ }^{138}$, como mais à frente, no " monólogo de Orfeu"139, quando parece nascer da unidade entre paixão e harmonia a inesquecível: "Se todos fossem iguais a você".

No momento em que o cotidiano e o encontro com Eurídice, identificados às entoações da fala (asseveração, interrogação, exclamação), harmonizam-se em letra e melodia, sob os cuidados do poeta, salta-se para outro plano, do sublime, mas não aquele que nos tira deste mundo, mas esse, de Vinícius (e também de Manuel Bandeira, de outra forma) que nos devolve ao mundo em um tom maior (ou melhor), como a surpresa de um achado, um encontro legítimo, pois se dá no momento mesmo em que se canta: realizado. É como se, sem perder o pulso do cotidiano, o sentimento existente vencesse o artifício das repetidas imitações sem vida $^{140}$.

Depois da morte de Eurídice, Orfeu não cria mais canções (os sons significativos da natureza também desaparecem), embora os sons produzidos por

serenando, em acordes que aos poucos se vão fazendo mais e mais alegres. Por fim o ritmo do samba já reponta [p.417].

${ }^{138}$ Eh! sambinha gostoso! estou te vendo

Descer o morro, meu samba...Ó turbilhão

e músicas em mim! Ih, já tem outra

Pronta para sair! Sossega idéia!

Calma violão! assim não adianta!

Vamos mais devagar...Deixa ver essa (dedilha)

Melodia ...Frase para uma canção....[p.408-9, grifos meus]

139، Mulher mais adorada!/Agora que não estás, deixa que rompa meu peito em soluços![...]e sabes de uma coisa? cada vez/ que o sofrimento vem, essa saudade/De estar perto, se longe, ou estar mais perto/ Se perto, - que é que eu sei! Essa agonia [...]Tudo isso/ Que é bem capaz de confundir o espírito /De um homem - nada disso tem importância/ Quando tu chegas com essa charla antiga/Esse contentamento, essa harmonia/ Esse corpo! E me dizes essas coisas/ Que me dão essa força, essa coragem/ Esse orgulho de rei/ Ah, minha Eurídice/ Meu verso, meu silêncio, minha música! / Nunca fujas de mim!/Sem ti sou nada /Sou coisa sem razão, jogada, sou /Pedra rolada. Orfeu menos Eurídice.../Coisa incompreensível[...]Vai te caminho que eu vou te seguindo/ No pensamento/[...]Vai tua vida que estarei contigo!"'p.414]

140 Antonio Cândido parece referir-se à poesia de Vinícius de Moraes da mesma maneira, quando vê nela não a repetição de traços, mas a origem mesmo deles que, pela imitação tão freqüente, perderam seu vigor inicial. Para o crítico: "Os poetas que valem realmente fazem a poesia dizer mais coisas do que dizia antes deles. Por isso precisamos deles para ver e para sentir melhor, e eles não dependem das escolas, porque as modas passam e os poetas ficam. Se hoje dermos um balanço no que Vinícius de Moraes ensinou à poesia brasileira, é capaz de não percebermos quanto contribuiu, porque, justamente por ter contribuído muito, o que fez de novo entrou para a circulação, tornou-se moeda corrente e linguagem de todos". "Vinícius de Moraes" in Moraes, Vinícius de.Poesia Completa, op. cit., p. 120. 
ele ao violão o tenham ajudado a entrar no clube dos "Maiorais do Inferno" à procura de Eurídice e continuem expressando sua dor ${ }^{141}$, ele não canta mais. Com Eurídice, morre também a sua inspiração sublime, confirmando o que ele afirmava em seu monólogo: "Orfeu menos Eurídice ... /Coisa incompreensível!" [p.414].

A cidade que ignora o morro é a mesma para onde desciam as canções do músico ${ }^{142}$, a mesma onde, seguindo as ordens de Plutão, "todo o mundo" cantava, "todo mundo" bebia, fora e dentro do clube dos "Maiorais do Inferno"[p.434], totalmente indiferentes ao sofrimento do "músico do morro", "porque a morte é certa" e o amanhã "é cinzas".

Lembrando os problemas da favela, que aparecem quando o músico deixa de cantar, poderíamos dizer que a morte de Eurídice significa a vitória da desmedida que "silencia" o canto ideal do poeta - e aqui residiria a tragédia mesma de Orfeu da Conceição. Seu padecimento não resulta de uma negação do sublime, como acontece no mito, quando Orfeu olha para trás, desobedecendo à condição imposta pelos deuses, mas, pelo contrário, de sua adesão total ao sublime, conjunção que se verifica, claramente, em suas exclamações: "Orfeu é o morro" e "Orfeu é Eurídice". Em um mesmo compasso, enquanto Orfeu é o morro, é Eurídice também; e vice-versa. Identificado ao lugar onde está, ele atinge o sublime.

Seu sentimento de culpa, portanto, observado como a consciência da limitação de seu canto, pode ser estendido à consciência de sua incapacidade de resolver os problemas expressos pelos reclamos da população do morro, (depois do enlouquecimento do músico), vencer o desprezo da cidade, representado pela "desmedida" daqueles que ignoram a dor de Orfeu.

\footnotetext{
141 "Toca um choro triste [p.432]"; o som do seu "violão que plange" domina a batucada do clube [p.430]; de seu instrumento, "correm escalas dulcíssimas em trêmulos e glissandos".

${ }_{142}$ "Eh! sambinha gostoso! estou te vendo/Descer o morro, meu samba...Ó turbilhão/ De músicas em mim!" [p.408], exclama Orfeu, ao terminar mais um samba".
} 
Nas últimas canções da peça ${ }^{143}$, vindas depois da morte de Eurídice, o ritmo, acentuado pelas notas curtas, sugere a conjunção entre o poeta e sua amada, mas as letras delas indicam o afastamento entre os dois. Espelhando esta contradição, as melodias são eufóricas, alegres, enquanto as letras são disfóricas. O efeito não é triste; junto à melodia, a expressão da saudade e da lembrança parece aproximar o casal, diminuindo a distância entre os dois. A sensação é a de que a composição da melodia transforma a dor expressa pelas palavras, tanto a dor de Orfeu, que faz a canção, como a dor do morro, que canta suas canções, mesmo após o estralhaçamento do músico e a volta da percepção dos problemas.

Acompanhando o final da peça, essas canções não são mais cantadas por Orfeu; a primeira delas surge na voz do "grupo de meninos engraxates", que se acomoda a um canto "sem dar muita atenção ao que se passa". Entre eles, a nova voz, que canta a música presenteada por Orfeu, é a expressão do novo Orfeu, "o maioral dos maiorais" - como, de algum modo, já prenunciava o músico, no início da peça ${ }^{144}$-, exortando não só o poder do canto que sobrevive a morte, mas também o poder do canto originado no morro contra a realidade dura descrita pelas queixas dos moradores da favela, que acompanham o desespero do músico.

Se por um lado, Orfeu é passivo, enquanto submetido aos "perigos dessa vida", sua ação existe, é canto que continua na voz das crianças e dos outros que repetem suas canções, mesmo depois de seu enlouquecimento; são as suas obras que ressurgem no final da peça, apesar (ou por causa) do seu padecimento; como se a capacidade criativa derivasse da exposição a esses "perigos"; exposição aparentemente passiva, porque se revela durante toda a peça como força criadora.

\footnotetext{
${ }^{143}$ Eu e o meu amor: "Eu e o meu amor/ E o meu amor .../Que foi-se embora/Me deixando tanta dor/Tanta triteza/No meu pobre coração/Que até jurou/Não me deixar/E foi-se embora/Para nunca mais voltar.../La-ra-ra-ra-la/La-ra-ri-la-ra-ra-ra" - Lamento no morro: "Não posso esquecer/O teu olhar/Longe dos olhos meus.../Ai, o meu viver/É te esperar/Pra te dizer adeus.../Mulher amada!/Destino meu!é madrugada/Sereno dos meus olhos já correu..." [p.447]

${ }_{144}$ Orfeu argumenta com sua mãe, quando esta, desistindo de tentar mover sua idéia de casar com Eurídice, diz desejar morrer: "Morrer sem ver/ O filho de seu filho, que vai ser/ O maioral dos maiorais? [p.406].
} 
A vida objetivada em suas canções continua expressa graças à sua capacidade de se submeter à dor, enfrentar os perigos da vida e mesmo descer aos infernos, entregando, devolvendo ou aludindo a quem canta ou ouve suas canções uma ordem (apolínea e dionisíaca) singular (porque parte de sua vivência) e plural (porque ecoa em nós) contra o caos do mundo (desmedido), ou emerso dele.

"E muito padeceu sob o poder maior da poesia", diz o "Credo" de Orfeu da Conceição, criador da melodia.

As impressões de Vinícius e a origem de Orfeu da Conceição

É interessante lembrar nesse momento das impressões de Vinícius sobre a cultura negra, impressões que foram as origens mesmas de sua peça.

Depois de ter presenciado vários festejos, era "como se o negro, o negro carioca no caso, fosse um grego em ganga - um grego ainda despojado de cultura e do culto apolíneo à beleza, mas não menos marcado pelo sentimento dionisíaco da vida". ${ }^{145}$ Embora Dionísio se relacione ao desregramento total, ele também simboliza a negação das convenções endurecidas que - quando sem culpa -aproxima-se do sentimento vital em seu grau maior. É esta força que parece ser expressa por Orfeu da Conceição e que parece ter sido percebida por Vinícius no morro.

$\mathrm{Na}$ peça, a desmedida dionisíaca em que a "alma parece morrer", observada por Paul Diel, ${ }^{146}$ no mito de Orfeu, quando este desobedece aos Deuses, não é característica do músico apaixonado do morro, mas dos animadores do baile dos Maiorais do Inferno, que desprezam o sofrimento de Orfeu, para "aproveitar a vida", "porque a morte é certa" e o "amanhã é cinzas" ; e das "bacantes" figuradas por Mira de Tal e pelos personagens que no morro se identificam ao clube da cidade, com a mesma urgência de "aproveitar a vida".

\footnotetext{
${ }^{145}$ Moraes, Vinícius. Cancioneiro. Op. cit., p. 25.

${ }^{146}$ Op.cit.
} 
Nesse sentido, Orfeu afasta-se de Dionísio, mas as canções criadas por ele, movidas pela paixão, confirmam, sem dúvida, a presença dionisíaca.

Orfeu da Conceição pode, em um primeiro olhar, ser visto apenas como uma drama particular. Aproximando-nos mais um pouco, pode ser visto como a expressão dos apaixonados. Aproximando-nos ainda mais, pode ser tomado como a expressão da mescla de forças dionisíacas e apolíneas harmonizadas no canto de Orfeu, que agem, juntas, como filtro do desbordamento dessas mesmas forças, próprio do mundo representado pela cidade e pela parte do morro identificada com ela.

Dionísio é o deus da desmedida e Apolo é o deus da harmonia (mas da guerra também ; com seu arco de prata e flechas de ouro ele conseguiu vingar os sofrimentos de sua mãe, matando o dragão que a perseguia). O canto de Orfeu traz a paz e sua paixão transforma-se em canto sublime. Orfeu é definido pelos moradores do morro como mantenedor da paz ${ }^{147}$. Oposto à Mira ${ }^{148}$ e a Clio $^{149}$, em nenhum momento ele faz referência à cor negra em tom pejorativo; em Eurídice, ressalta a pele negra e também os dentes brancos. O branco é a cor da lua admirada por ele, que retoma a música de origem africana, quando afugenta a Dama Negra ${ }^{150}$. É a sua música, cantada pelos meninos, que se mistura à oração católica "Salve Rainha". Suas atitudes expressam, além da valorização da cultura negra e a convivência harmoniosa com a cultura branca, um posicionamento particular frente ao mundo, que o diferencia e é a origem de seu canto. Suas canções recuperam ainda os cantos rituais negros enquanto expressão, presságio

\footnotetext{
${ }^{147}$ Uma das canções de Orfeu, cantada pelas crianças, depois de sua morte, diz: "Paz muita paz/ Que falta nesse mundo faz, rapaz..." [p.446]

${ }_{148}$ Mira referindo-se a Eurídice: "Talvez você [Orfeu] precise [...] de alguma mulatinha de pedreira/metida à branca!”. [p.416]

${ }^{149}$ Clio referindo-se a Eurídice depois do enlouquecimento de Orfeu: "Ah, Deus do céu/Me leva bem depressa que é pra eu encontrar aquela negra [...] E tudo isso/Por causa de uma suja descarada/Uma negrinha que nem graça tinha [...]".[p.439]

150 "(Põe-se a tocar furiosamente em seu violão, em ritmos e batidas violentos. Os sons, à medida que se avolumam, vão criando uma impressão formidável de magia negra, macumba, de bruxedo) [...] (A Dama Negra, ao ritmo que se desenvolve cada vez mais rapidamente, põe-se a dançar passos de macumba, a princípio lenta, depois vertiginosamente, na progressão da música.) [...] (O movimento segue num crescendo infinito, até que, exausto, Orfeu para, com macabro e demoníaco som do violão[...]."[p.421]
} 
e prevenção. Enfim, Orfeu traz a harmonia serena apolínea à paixão dionisíaca, assim como o pulsar dionisíaco da vida à concentração de Apolo. Orfeu é o "músico total"151.

A peça finalmente traz do mito a hesitação extremamente humana entre os valores terrenos, identificados a Dionísio, e os espirituais, identificados a Apolo, mas que é de alguma forma resolvida nas canções - que não eliminam nem as causas, nem os problemas derivados delas, que continuarão sempre a existir-, numa comunhão do tempo finito, em que o canto penetra em nós, e do tempo infinito, em que permanece conosco, completando sua criação.

As atitudes de Orfeu da Conceição identificam-se ao conceito grego da Aretê, cuja origem remonta aos tempos de Orfeu. Ela corresponde ao comportamento do homem derivado de um processo de auto-educação permanente, sempre submetido à diversidade de cada época (e às adversidades de todos os tempos). A origem deste processo contínuo e pessoal de formação corresponde ao momento em que homem e mundo estavam integrados de tal forma ("idade de ouro") que os princípios éticos não eram expressos por leis a serem obedecidas, externas a ele, mas a determinações internas derivadas da integração sem mediações entre o homem e o mundo, que sinalizavam seu comportamento.

Esse processo de auto-formação parece corresponder, justamente, ao surconsciente a que Paul Diel se refere, ou seja, a uma disposição ética que impulsiona as atitudes do homem expressas principalmente pelas artes. ${ }^{152}$ As canções de Orfeu são expressões finais de sua Aretê, de sua identificação ao morro e a sua paixão. Através delas a desmedida do mundo é transformada de maneira singular em arte.

A peça de Vinícius, vista dessa forma, aponta o desejo ideal de seu autor, figurado pelo músico total, e, ao mesmo tempo, uma crítica, enquanto contrapõe Orfeu à cidade, tida como metáfora da morte trágica de Eurídice que emudece o canto.

\footnotetext{
${ }^{151}$ Moraes, Vinícius. Orfeu. Op. cit. p. 27.

152 Op. cit.
} 
Quando houve revolução os soldados se espalharam no morro, O quartel pegou fogo, eles não voltaram.

Alguns chumbados morreram.

O morro ficou encantado.

Mas as vozes do morro Não são lúgubres. Há mesmo um cavaquinho bem afinado Que domina os ruídos da pedra e da folhagem E desce até nós, modesto e recriativo, como um gentileza do morro

[“Morro da Babilônia”, em Sentimento do mundo [1940], de Carlos Drummond de Andrade ${ }^{153}$ ]

O erudito e o popular

Orfeu da Conceição e o contexto em que a peça é escrita

Desde a década de 30, passando pela de 40, quando Vinícius escreveu o primeiro ato, e a de 50, quando terminou a peça Orfeu da Conceição, ainda eram marcantes as idéias de democracia racial e originalidade tropical refletindo as obras de sociólogos e escritores como Gilberto Freire (Casa grande e senzala, 1933), de Jorge Amado etc.., frontalmente contrárias às teorias racistas do início do séc. $X X$, defendida até mesmo por intelectuais renomados como Sílvio Romero, que viam a miscigenação no Brasil, sobretudo a derivada dos negros,

${ }^{153}$ In: Reunião. Op. cit., p. 49. 
como um dos grandes males, causa, inclusive, de seu atraso frente a países tidos como desenvolvidos ${ }^{154}$.

O relato de Vinícius sobre o percurso e diálogo com o escritor americano Waldo Frank, a quem o poeta acompanhava pelas favelas do Rio, é exemplo do seu entusiasmo frente às manifestações da cultura de origem africana entre nós:

Acompanhava eu o autor de América Hispana em todas as incursões por favelas, macumbas, clubes e festejos negros do Rio, e me sentia particularmente impregnado do espírito da raça. Conversa vai, criou-se subitamente em nós, através de um processo por associação caótica, o sentimento de que todas as celebrações e festividades a que vínhamos assistindo tinha alguma coisa a ver com a Grécia; como se o negro, o negro carioca no caso, fosse um grego em ganga - , um grego ainda despojado de cultura e do culto apolíneo à beleza, mas não menos marcado pelo sentimento dionisíaco da vida.

Posteriormente, na viagem que fiz ao norte do Brasil, o espetáculo dos candomblés, das capoeiras e dos festejos negros da Bahia só fizeram fortificar essa impressão. ${ }^{155}$

De acordo com Ruy Castro, sob a influência deste escritor americano, Vinícius de Moraes "mudará sua visão política - da direita, com a qual simpatizava, para a esquerda" ${ }^{156}$. O relato sobre a origem da peça, baseada no mito de Orfeu, registra a importância desse seu contato com a cultura do morro e o desejo de expressar isso de forma artística:

Orfeu aconteceu em 1942.

Eu estava uma noite na casa de Carlos Leão, no morro do Cavalão, lendo o mito de Orfeu, um mito que sempre me interessou muito por causa do poeta, do músico total, e por causa da relação sublime do amor dele por Eurídice. Talvez tenha sido isso.

Devia ser meia-noite e, de repente, como se eu tivesse tido um radar de um momento especial, as duas idéias se fundiram, de graça, o ovo de Colombo. Como se eu tivesse sido instrumento de um momento especial.

\footnotetext{
${ }^{154}$ O excelente documentário de João Salles, Jorge Amado, produzido em 1995, traduz com maestria o perigo do poder da insensatez, ainda maior quando traz para si o discurso racional científico.

${ }^{155}$ Moraes, Vinícius de. Cancioneiro Vinícius de Moraes: Orfeu: Songbook/ músicas de Antonio Carlos Jobim e Vinícius de Moraes, op. cit., p.25.

${ }^{156}$ Cf. Moraes, Vinícius de. Querido poeta: correspondência de Vinícius de Moraes/ seleção, organização e notas Ruy Castro. São Paulo: Companhia das Letras, 2003, p.101.
} 
Eu senti no morro negro uma série daqueles elementos que eu estava lendo. As paixões, a música, o negócio da poesia, a gratuidade de tudo aquilo...

Essa impressão positiva sobre o morro contrasta com a imagem, persistente até os dias de hoje, de miséria e degradação humana.

O conflito entre a cidade e o morro, em Orfeu da Conceição, é explicitado apenas no final da peça ${ }^{157}$, depois da morte de Orfeu, pelas queixas dos moradores do morro, no entanto, esse desfecho, que coincide com a loucura e o silêncio do cantor, é bastante revelador. Esses diálogos finais localizam a tragédia de Orfeu da Conceição, apontando uma complexidade maior à qual podemos chegar, quando nos aproximamos do contexto da peça, ou, ainda, da origem das favelas no morro do Rio de janeiro, no final do século XIX e começo do XX, início do conflito entre morro e cidade estendido até os dias de hoje.

As favelas, conforme foram logo denominados os morros, nasceram antes das Ciências Sociais, ou seja, antes de estudos dotados de uma perspectiva científica baseada na coleta de dados, que abrangesse, inclusive, depoimentos dos próprios moradores. Desde seu início, as informações sobre as favelas vinham ora como denúncia do estado de miserabilidade em que as pessoas se encontravam, exigindo o apoio institucional a elas, ora como alerta do perigo que representavam ao desenvolvimento da cidade. ${ }^{158}$

Para Licia Valladares, socióloga que estuda a favela desde a década de 60 e que realizou uma pesquisa excelente sobre o processo de construção do imaginário social sobre a favela, a representação inicial desse conflito foi bastante influenciada por Os sertões. O livro de Euclides da Cunha, lançado em 1902, com segunda edição em 1903 e terceira, em 1905, ter-se-ia transformado numa espécie de "mito de origem" ao qual não só jornalistas, mas também os

\footnotetext{
${ }^{157}$ Antes, mas de maneira menos evidente, esse conflito aparece no desabafo de Clio que "lava roupa até comer o sabugo" e, como bem salientou a prof. Raquel Illescas Bueno, em sua argüição durante a defesa da presente tese, em outra fala da mesma personagem: "pobre não casa", [p. 405].

${ }^{158}$ Valladares, Licia do Prado. "A gênese da favela carioca : a produção anterior às Ciências Sociais", in: Revista Brasileira de Ciências Sociais, v. 15, n.44. São Paulo, outubro de 2002.
} 
reformadores sociais recorriam ao descreverem o morro, "permitindo o desenvolvimento de um imaginário coletivo sobre o microcosmo da favela e seus moradores, ao mesmo tempo em que opunham favela e cidade". São muitos os exemplos colhidos pela socióloga em que a oposição "sertão versus litoral" é transportada para a oposição "favela versus cidade". Para ela,

De fato, a leitura de textos escritos no início do século leva a associar o Morro da Providência, no Rio de Janeiro, ao povoado de Canudos, no sertão baiano. Na verdade, as duas histórias se sobrepõem, pois foram antigos combatentes da Guerra de Canudos que se estabeleceram no Morro da Providência, a partir daí denominado Morro da Favella. A maior parte dos comentaristas apresenta duas razões para a mudança do nome: 19 a planta favella, que dera seu nome ao Morro da Favella - situado no município de Monte Santo, no Estado da Bahia - ser também encontrada na vegetação que recobria o Morro da Providência; e 29 a feroz resistência dos combatentes entrincheirados nesse morro baiano da Favella, durante a guerra de Canudos, ter retardado a vitória final do exército da República, e a tomada dessa posição representando uma virada decisiva da batalha.

Se a primeira explicação diz respeito apenas a uma similitude, a segunda tem uma forte conotação simbólica que remete à resistência, à luta dos oprimidos contra um adversário poderoso e dominador. [...]

O livro de Euclides da Cunha é posterior (1902) ao momento em que o Morro da Providência foi rebatizado como Morro da Favella (1887), mas tal acontecimento teria passado despercebido, e essa palavra não teria alcançado a posteridade que conheceu, sem as imagens fortes e marcantes transmitidas através de Os sertões. Imagens capazes de permitir aos intelectuais brasileiros compreender e interpretar a favela emergente. ${ }^{159}$ [grifo meu].

É surpreendente a observação de Licia a respeito da influência de Os sertões, sobretudo, porque traz à favela, ou às noções negativas que vão sendo associadas a ela, aspectos positivos também como a "idéia de comunidade", de "miseráveis", sim, mas "com extraordinária capacidade de sobrevivência diante das condições de vida extremamente precárias e inusitadas, marcados por uma

159 Idem. $A$ invenção da favela - do mito de origem à favela.com. $1^{\circ}$ Ed. Rio de Jan eiro: Editora FGV, 2005, p. 29-30. 
identidade comum". A favela é "percebida como espaço de liberdade e como tal valorizada pelos seus habitantes" ${ }^{\prime 160}$.

Além de esclarecer o "percurso que pouco a pouco foi levando à construção de um conhecimento sobre a favela carioca", a observação da socióloga sobre esse aspecto positivo relativo à favela remete-nos prontamente aos sambas, do início do século XX (embora a autora não faça menção a isso), cujo tema é o morro tomado favoravelmente, transpondo a constante associação entre este e a miserabilidade.

É "por ocasião de uma seresta" que João do Rio, o "cronista flâneur", sobe até o morro, construindo, com seu artigo, a "ponte" a que Lícia se refere, que leva o leitor de jornalistas e cronistas "até o alto do morro que ele, membro da classe média, não ousava subir"161.

Outra referência despercebida à música, transpondo a pobreza material, está no depoimento de Maria Hortência do Nascimento e Silva, assistente social, autora de um dos primeiros estudos sobre as favelas, cujos "valores e preconceitos quanto aos pobres tornam-se mais evidentes, quando discute (capítulo III) o problema da favela que 'urge por uma solução'”162. A referência positiva ao canto - que pode ser tomado também como uma forma de resistência - vaza o discurso preconceituoso da assistente, sem que ela perceba:

Filho de uma raça castigada, o nosso negro, malandro de hoje, traz sobre os ombros uma herança mórbida por demais pesada para que a sacuda sem auxílio, vivendo no mesmo ambiente de miséria e privações; não é sua culpa se antes dele os seus padeceram na senzala, e curaram suas moléstias com rezas e mandingas.[...] É de espantar, portanto, que prefira sentar-se na soleira da porta, cantando, ou cismando, em vez de ter energia para vencer a inércia que o prende, a indolência que o domina, e resolutamente pôr-se a trabalhar? [...] Para que ele o consiga, é preciso antes de nada curá-lo, educá-lo, e, sobretudo, dar-lhe uma casa onde o espere um mínimo de conforto indispensável ao desenvolvimento normal da vida. [grifo meu]. [Silva, M.H.do Nascimento e. Impressões de uma assistente social sobre o trabalho na favela. Rio de Janeiro: Prefeitura do Distrito Federal, Secretaria Geral de Saúde e Assistência/Gráfica Sauer, 1942, p. 623. Apud Valladares, Licia. Op.cit.].

\footnotetext{
${ }^{160}$ Idem. "A gênese da favela carioca: a produção anterior às Ciências Sociais". Op. cit.

161 Idem, Ibidem, p. 7.

162 Idem, p. 26.
} 
É interessante lembrar que apesar das várias edições de Os sertões e de toda a divulgação do livro feita pela imprensa, os autores dessas canções provavelmente não tiveram acesso a ele. Evidentemente, a pobreza material do morro era fato, mas a "extraordinária capacidade de sobrevivência diante das condições de vida extremamente precárias e inusitadas, marcados por uma identidade comum"163, percebida em Canudos, assemelha-se a esse canto vindo na contramão do que se divulgava como verdade a respeito da vida nos morros.

As favelas derivadas da "intensificação da taxa de crescimento urbano" e da "expulsão da população humilde da área central da cidade" são exemplos do descaso a que eram relegadas pelas autoridades, na primeira república, "as pessoas humildes" ${ }^{164}$. Escritores como Lima Barreto, como aponta Nicolau Sevcenko, tomavam-nas como exemplo do "abandono completo do povo", "aspecto mais dramático da cena republicana":

Eis com que dorida sutileza o autor [Lima Barreto] transfundia as favelas que cingiam os cumes dos morros cariocas no verdadeiro diadema do regime: "os pobres, os mais pobres, de mistura em toda espécie de desgraçados, criminosos e vagabundos, ocupavam as eminências urbanas com casebres miseráveis, sujos, feios, feitos de tábuas de caixões de sabão e cobertas com folhas desdobradas de latas em que veio acondicionado o querosene. Era a coroa, o laurel daquela glacial transformação política". ${ }^{165}$

A descrição feita por Lima Barreto da penúria na qual viviam os moradores do morro, na primeira década do século, assemelha-se às encontradas nos jornais da época, não se afastando da imagem de Canudos, do "mito de origem" das primeiras representações da favela, constatado por Licia Valladares.

Em seguida a este período, as favelas são definidas por jornalistas, médicos sanitaristas etc. como "problema a ser resolvido" que comprometia o

\footnotetext{
${ }^{163}$ Valladares, Licia. Op.cit., p. 10.

164 Sevcenko, Nicolau. Literatura como missão: Tensões sociais e criação cultural na Primeira República. $2 \%$ d. São Paulo. Companhia das Letras. 2003, p. 56. [agradeço a André Luís Rodrigues a indicação desta obra].

${ }_{165}$ Idem, op. cit., p..226-7. Apud. Barreto, Lima. Vida e morte de M. J. Gonzaga in.: Obras completas de Lima Barreto. Org. Francisco de Assis Barbosa. São Paulo: Brasiliense, 1956, 17 vols, p. 268-9.
} 
desenvolvimento urbanístico da capital do Brasil. Nos anos 1926-7, é promovida uma grande campanha contra elas, com o apoio de jornais e dos poderes públicos, liderada por Mattos Pimenta, "personagem importante no meio dos negócios no Rio, no final dos anos 20", "membro ilustre do Rotary Club", "a que se filiou em 1925 “, como "construtor imobiliário e corretor de imóveis", mas "apresentado às vezes como médico especialista em questões sanitárias, às vezes como engenheiro e jornalista". Segundo Licia Tavares ${ }^{166}$ :

Durante dois anos, essa campanha, muito bem organizada, ocupou as páginas dos principais jornais do Rio - O Globo, A Notícia, Jornal do Commercio, O Jornal, Correio da Manhã e Jornal do Brasil -, apresentando a favela como "lepra estética". Esta analogia sintetiza perfeitamente a maneira pela qual Mattos Pimenta denunciava a pobreza. [...] ainda nos anos 20 [a lepra] constava como uma das piores doenças contagiosas, desfigurando e levando à segregação os doentes por ela infectados. Para Mattos Pimenta a favela exigia medidas de rigor:

"[...] antes mesmo de sua adopção [do plano de remodelamento do Rio de Janeiro] é mister se ponha um paradeiro immediato, se levante uma barreira prophilactica contra a infestação avassaladora das lindas montanhas do Rio de janeiro pelo flagello das favelas - lepra esthetica, que surgiu ali no morro, entre a Estrada de Ferro Central do Brasil e a Avenida Cães do Porto e foi se derramando por toda a parte, enchendo de sujeira e de miséria preferentemente os bairros mais novos e onde a natureza foi mais pródiga de beleza.[...]

Desprovidos de qualquer espécie de policiamento, construídas livremente de latas e frangalhos em terrenos gratuitos do Patrimônio Nacional, libertadas de todos os impostos, alheias a toda ação fiscal, são excellente estímulo à indolência, attraente chamariz de vagabundos, reducto de capoeiras, valhacoito de larápios que levam a insegurança e a intranqüilidade aos quatro cantos da cidade pela multiplicação dos assaltos e furtos". ${ }^{167}$

Logo depois, "relacionada ou não a essa primeira campanha anti-favela, a verdade é que, em 1928, em pleno Carnaval, assistiu-se a derrubada de várias centenas de barracos pelo Prefeito Antonio Prado Júnior, obrigando seus moradores a buscarem por conta própria outros locais de moradia". ${ }^{168}$

\footnotetext{
${ }^{166}$ Valladares, Licia. A invenção da favela. Op. cit., p. 42.

167 Como informa Licia Valladares, o trecho transcrito faz parte do discurso feito por Mattos Pimenta "em almoço no Rotary Club do Rio de Janeiro, em 12 de novembro de 1926, levando o título de 'As Favellas', e reproduzido no Correio da Manhã e O Jornal, ambos de 18 de novembro de 1926".

${ }^{168}$ Valladares, Licia. A invenção da favela. Op. cit.,. p.44.
} 
Com influência ainda das idéias de Mattos Pimenta, da-se início a elaboração do Plano Agache de "extensão, renovação e embelezamento da capital do país" dando forma "às representações das elites", "endossando a idéia de que a favela representava um sério problema, 'não só do ponto de vista da ordem social e da segurança, como sob o ponto de vista da higiene geral da cidade, sem falar da estética'” ${ }^{169}$.

É importante observar que já em 1905, "em plena reforma Pereira Passos", o engenheiro Everardo Backeuser, escolhido para dar um parecer sobre "o problema das habitações populares", observava o problema de higiene nas favelas, mas "com uma percepção distanciada das representações correntes sobre sua população", assim descritas por ele

Alli não moram apenas os desordeiros e os facinoras como a legenda (que já a tem a favela) espalhou; ali moram também operários laboriosos que a falta ou a carestia dos cômodos atira para esses logares altos, onde se goza de uma barateza relativa e de uma viração que sopra continuamente dulcificando a rudeza da habitação. ${ }^{170}$

Contrariando também a "legenda" que se construía sobre a favela, os pintores modernistas, já no início dos anos 20, como Tarsila do Amaral, Di Cavalcanti, Lazar Segall e Portinari, conforme sugere o estudo de BerensteinJacques, transformaram as favelas "em símbolo da cultura nacional". Além deles, Blaise Cendras, "que esteve no Brasil em diversas oportunidades entre 1924 e 1929", chegou "até mesmo a criticar os planos urbanísticos da prefeitura implicitamente, o plano Agache". ${ }^{171}$.

Somam-se a eles, no sentido de defini-las, os próprios dados do primeiro recenseamento das favelas do Rio de Janeiro de 1948 e o recenseamento geral do Brasil de 1950, que negavam ser o morro lugar de concentração de "ladrões,

\footnotetext{
${ }^{169}$ Idem. "A gênese da favela carioca".Op. cit.,. p.20. [Apud. Agache, Alfred. In Cidade do Rio de Janeiro: extensão - remodelação - embelezamento. Rio de Janeiro:Prefeitura do Distrito Federal, 1930].

${ }^{170}$ Idem. A invenção da favela. Op.cit., p. 38. Apud. Backeuser, Everardo. Habitações populares.

In: Relatório apresentado ao Exm? Sr. Dr. J.J.Seabra, ministro da Justiça e Negócios Interiores.Rio de Janeiro: Imprensa Nacional, 1906.

${ }_{171}$ Idem, ibidem, p. 46-7. Apud. Berenstein-Jacques, Paola. Les favelas do Rio:un jeu culturel. Paris-L'Harmatathan, 2001.
} 
desocupados, migrantes e analfabetos". Sua população era composta, na realidade, em sua grande maioria de trabalhadores, de imigrantes portugueses, espanhóis e italianos. O número dos habitantes que os jornais divulgavam como sendo entre 400 a 600 mil, era, em 1950, 169.305. Ironicamente ainda, os dados gerais, como aqueles relacionados à alfabetização, eram bastante próximos aos verificados no restante da cidade. Mesmo assim, os comentários e as interpretações divulgadas demonstraram "preconceitos sociais e raciais", "chegando a invocar biologia e raça, com viés eugenista". Nos trechos dessas avaliações, selecionados por Licia Tavares, lemos ${ }^{172}$ :

Não é de surpreender o fato de os pretos e pardos prevalecerem nas favelas. Hereditariamente atrasados, desprovidos de ambição e mal ajustadosos às exigências sociais modernas, fornecem em quase todos os nossos núcleos urbanos os maiores contingentes para as baixas camadas da população" [Prefeitura do Distrito Federal, 1949:8]

[...] O preto, por via de regra, por exemplo, não soube ou não pode aproveitar a liberdade adquirida e a melhoria econômica [...] Renasceu-lhe a preguiça atávica, retornou a estagnação que estiola, [...] priva-se do essencial à manutenção de um nível de vida descente, mas investe somas relativamente elevadas em indumentária exótica, na gafieira e nos cordões carnavalescos, gastando tudo, enfim, que Ihe sobra da satisfação das estritas necessidades de uma vida no limiar da indigência [Prefeitura do Distrito Federal, 1949:10-11]. [grifo meu]

O discurso oficial vinha ao encontro do objetivo da feitura do recenseamento, ou seja, retornar a "uma política prioritariamente de erradicação das favelas".

Se antes na descrição da assistente social, Maria Hortência do Nascimento e Silva, o canto era resultado da falta total de perspectiva, de uma quase doença inata, agora, no discurso oficial, enraivecido e novamente preconceituoso, canto e dança são vistos como uma espécie desperdício irresponsável.

Orfeu da Conceição, ao contrário, ressoava nesta mesma época, as observações do o engenheiro Everardo Backeuser, em 1906, dos pintores

${ }^{172}$ Idem, ibidem, p. 66 
modernistas brasileiros, de Blaise Cendras, durante a década de 20 e, surpreendentemente, os dados do recenseamento de 1948, escamoteados pelo "preconceito racial mais rasteiro". A peça trazia ainda a voz que vinha das canções desde o início do aparecimento das favelas. Trazia o canto não como expressão de abolia ou desperdício, mas valor central do morro.

Se essa positividade do morro distancia-se das impressões dos meios de comunicação contemporâneos à peça, aproxima-se, por outro lado, do que era expresso, justamente, pela música popular ${ }^{173}$, que considerava o morro como lugar de solidariedade, de alegria, onde se "faz festa em troca de amizade"174, exaltando a camaradagem, liberdade etc. existentes no morro, como em Canudos aos olhos de Euclides da Cunha.

Ao ouvir essas canções, a impressão frente aos textos que descreviam a vida na favela e a sua população é a de que o tema sobre o qual se fala é outro. Elas enaltecem não só o lugar, mas também os laços de vizinhança, companheirismo e união. Em nítida oposição à "cidade", onde predominariam as relações impessoais, a favela seria o lócus, por excelência, das relações personalizadas, e não o lócus da pobreza: nela, todos se conhecem, todos se ajudam, "todo vizinho é amigo da gente" 175.

O samba de Sinhô, Favela vai abaixo, "lançado em 28 como forma de lamento pela destruição do morro da Favela, previsto pelo Plano Agache para a cidade do Rio de Janeiro" ${ }^{176}$ é um bom exemplo disso:

\footnotetext{
173 Sobre a representação da favela no cancioneiro popular (conflitos, preconceitos, estigmas etc..), cf.: Oliveira, Jane Souto e Marcier, Maria Hortense. Op. cit.

174 O verso é da canção "Vida no morro", de Anibal Cruz (1942) [Apud. Oliveira, Jane Souto e Marcier, Maria Hortense. Op. cit.:

[...] Tudo no morro é diferente

Todo vizinho é amigo da gente

Até o batuque nossa maravilha

Toda cabrocha é descente família

Tudo no morro é melhor que na cidade

175 Idem

Tanto na cor como na felicidade [...]

${ }^{176}$ Oliveira, Jane Souto e Marcier, Maria Hortense. Op. cit., p.61.
} 
Seresteiro:

Minha cabocla, a Favela vai abaixo!

Quanta saudade tu terás deste torrão

Da casinha pequenina de madeira

Que nos enche o coração! [...]

Mulata:

No Estácio, Querosene ou no Salgueiro

Meu mulato não te espero na janela

Vou morar na cidade nova

Pra voltar meu coração para o morro da favela! [... $]^{177}$;

Favela querida, de Cristóvão de Alencar e Sílvio Pinto, de 1940, é outro bom exemplo:

Minha Favela querida

Se eu for para outro lugar

Na hora da despedida

Eu bem sei

Que vou chorar [...]

Favela dos sonhos meus,

Não sei dizer adeus ${ }^{178}$;

como também Chão de estrelas (1937), de Orestes Barbosa:

A porta do barraco era sem trinco.

Mas a lua, pisando nosso zinco,

Salpicava de estrelas nosso chão $[\ldots]^{179}$;

E o famoso samba de Herivelto Martins, Ave Maria no morro, de 1942, mesmo ano em que Vinícius começou a escrever sua peça, é o melhor exemplo de oposição à imagem negativa do morro:

\footnotetext{
177 Idem, p. 65.

178 Idem, p. 67

179 Idem, p. 53.
} 
Barracão de zinco

Sem telhado, sem pintura

Lá no morro

Barracão é bungalow

Lá não existe, felicidade arranha-céu

Pois quem mora lá no morro

Já vive pertinho de céu $[\ldots]^{180}$

No texto "A palavra é favela" ${ }^{181}$, há uma relação de 125 músicas cujo tema gira em torno da favela. De acordo com Licia Tavares, Maria Hortense Marcier e Alba Zaluar ${ }^{182}$, suas autoras,

sugerem em sua análise que paralelamente à configuração como espaço do pobre, a favela também se constitui como espaço do samba. Na representação musical aparece igualmente a sua imagem como não cidade, como lócus da marginalidade urbana e também, a partir de 1960 , como questão social ${ }^{183}$.

Enquanto representação positiva da favela, as canções guardam, ao mesmo tempo que expõem, o enigma da planta resistente, comum à região de Canudos e ao morro carioca, ao qual ela passou a nomear. A descrição dessa planta, feita por Euclides da Cunha, parece significar muito mais do que um registro científico ou jornalístico:

As favelas, anônimas ainda na ciência - ignoradas dos sábios, conhecidas demais pelos tabaréus - talvez um futuro gênero cauterium das leguminosas, têm, nas folhas de células alongadas em vilosidades, noteis aprestos de condensação, absorção e defesa. Por um lado a sua epiderme ao esfriar-se à noite, muito abaixo da temperatura do ar, provoca a despeito da secura deste, breves precipitações de orvalho; por outro, a mão que a toca, toca uma chapa incandescente de ardência inaturável" ${ }^{184}$.

${ }^{180}$ Idem, p.73

${ }^{181}$ Op. cit.

${ }^{182}$ Op. cit.

${ }^{183}$ Op. cit. p. 33.

${ }^{184}$ Cunha, Euclides da. O sertões: (campanha de Canudos). [1902]. São Paulo: Ateliê Editorial/Imprensa Oficial do Estado, 2001. (Edição, prefácio, cronologia, notas e índices de Leopoldo M. Bernucci), p. 121. Apud. Tavares, Licia. Op. cit. A chamada de atenção para essas características da planta favela foi feita pelo professor José Miguel Wisnik, a quem agradeço muito. 
Voltando a Orfeu da Conceição

A paixão é marca dionisíaca do músico do morro. A luz apolínea o acompanha aonde vai, como um nascimento de sol encobrindo a noite. A harmonia é uma constante não só de suas canções, mas de seus juízos de valor contrários a julgamentos convencionais, já mecanizados, como os de culpa e perdão. Diferentemente dos outros moradores da favela, o músico traz consigo uma tradição musical transmitida por Apolo: seu pai ensinou-Ihe tudo: "da posição à harmonia". Reforçando a idéia de composição harmônica, ou apolínea, as características formais da peça como a obediência à unidade de ação, os versos decassílabos, a presença do Corifeu, antecipando os acontecimentos que se seguirão, e do coro, como voz da comunidade (opinando sobre o final trágico) compõem a tragédia de Orfeu.$^{185}$.

Orfeu da Conceição, que a partir do que observou Vinícius, pode ser lida como uma celebração do caráter dionisíaco do morro, pode ser lida também como uma harmonização apolínea da plenitude de vida dionisíaca ou ainda, de maneira talvez mais correta, possamos dizer que a peça traduz o desejo dionisíaco, no melhor dos sentidos, de Vinícius de Moraes: a dissolução das diferenças raciais, intelectuais e de classe simbolizada por Orfeu - que não é Apolo nem Dionísio-, mortal como qualquer outro homem que não perdeu - na terra -, seu poder de se dar conta disso (da morte e de sua capacidade criadora) e, também por este motivo, poder cantar harmoniosamente (para graça de todos os outros homens) originando sua ordem particular no caos.

A peça pode ser definida como um teatro poético tanto por causa das canções, do soneto e dos diálogos em versos, mas porque todo o texto é a extensão do lirismo de Orfeu. Tudo o que cerca o cantor é trampolim para a expressão deste "eu-lírico", desde o início da peça, de sua submissão à paixão. Vinícius consegue assim, sobretudo por causa da unidade representada entre o

\footnotetext{
${ }^{185}$ Sobre a observância às convenções da tragédia assim como o domínio delas por Vinícius, a fim de acentuar o drama vivido por Orfeu cf.: Paranhos, Luiz Tosta. Op.cit.
} 
mito e o meio em que vive, representar a saga heróica ${ }^{186}$ de Orfeu e dialogar de maneira verossímil com realidades contemporâneas à peça, ou seja: a proximidade entre a cultura erudita e popular (a primeira valorizando a segunda); o poeta idealizado como "voz do morro", mas tido também como malandro (traço observado no desabafo de Clio); a indiferença social da cidade em relação ao morro e a marcada expressão da cultura negra tanto pelos cantos como também pela dança e capoeira.

Essa capacidade evidenciada dos morros/canto de se transformar (qualidade mesma do samba, cuja "origem primeira" foi a senzala) em arte parece ser o seu recado maior. Talvez venha dessa força a identificação entre os poetas da cidade como Manuel Bandeira e a população do morro, sobretudo seus cantores; talvez seja por isso que os artistas, de alguma forma sempre gauches na vida, tenham se sentido em casa, quando deram vez/voz ao morro.

A aproximação entre o mito grego e a cultura negra do morro é composta na peça pela fluência de "formas populares de expressão" produzindo os versos de diferentes medidas (próprias da linguagem literária erudita), revezando-se com formas da língua culta, numa combinação hábil, como bem demonstra o crítico Luiz Tosta Paranhos ${ }^{187}$, o que vem a colocar Vinícius, também por esse motivo, entre os vários intelectuais de sua época voltados para essa cultura.

É, sobretudo, a fala do mundo cotidiano do morro e da cidade que compõe as canções de Orfeu nas quais ele harmoniza Dionísio e Apolo, como também o erudito e o popular. De acordo com o professor e músico Luiz Tatit, a Bossa Nova, diretamente relacionada às canções de Vinícius de Moraes e Antonio Carlos

\footnotetext{
${ }^{186}$ Retomo aqui o pressuposto de Anatol Rosenfeld, para o qual o herói mítico só pode ser concebido na época heróica, quando não há mediação entre o herói e o meio em que vive. Cf. Rosenfeld, Anathol. Op. cit. Neste sentido é interessante observar, além da unidade entre Orfeu e o meio em que vive, as peculiaridades do cantor, poeta e músico, que o diferenciam tanto dos outros moradores da favela como, principalmente, dos moradores da cidade.

187 "A par dessas formas populares de expressão ['mistura de tratamento - tu/você [...] emprego constante de diminutivos afetivos [...] emprego de duas negativas'] encontramos outras da língua culta, numa combinação hábil. Também se empregam formas cristalizadas do folclore, como o 'Quem sois tu?' [...] de Plutão dirigido a Orfeu/Vale a pena realçar como se faz a referência à cor dos atuantes, quer numa função referencial, quer numa emotiva, formando uma hipálage, ambas englobadas pela poética: 'Não, meu neguinho. Pelo amor de Deus/Ainda não, ainda não' [...] 'Mulata, pele escura dente branco.". "A língua literária de Orfeu da Conceição", in Orfeu da Conceição, op. cit.,p. 53-4.
} 
Jobim, tem como origem a passagem das inflexões da fala (assertivas, exclamações, interrogações) para a canção, o que indica que a canção venha da fala e não da música ou da literatura. Esta grande diferença teria proporcionado a possibilidade de se fazer canções sem a necessidade de uma formação musical. O novo canto deu voz ao morro em forma de música, voz que se ouvia nos encontros na casa da Tia Ciata, com a presença de Sinhô e Manuel Bandeira ${ }^{188}$.

Depois da morte de Eurídice Orfeu não faz mais canções, mesmo quando invade o Clube dos maiorais, o som do seu violão ajuda-o a entrar, mas ele não canta mais. Com Eurídice morre também a sua inspiração. Como ele dizia: "Orfeu menos Eurídice... /Coisa incompreensível". Mas a consciência do poeta Vinícius, concordando com a experiência do mito grego, traz a nós os meninos cantando as suas canções e, entre eles, um novo Orfeu. Esse Orfeu da Conceição traduz a convicção de que só é possível chegar ao sublime poético, mergulhando na vida terrena, com o corpo ou apesar dele.

É interessante lembrar agora as palavras de Orfeu da Conceição, afugentando a morte: "Orfeu é a vida/ No morro ninguém morre antes da hora. Esta morte "antes da hora" pode não se relacionar apenas à morte física, que, por falta de assistência, acontece ainda nos morros - e não só nos do Rio de Janeiro e nem só nos morros-, mas a morte em vida também.

A força dionisíaca da cultura negra é a origem do Orfeu da Conceição, de Vinícius de Moraes. Parece ser essa força que, como lapso, depreende-se do depoimento da assistente social e do discurso de avaliação do recenseamento de 1950, mostrando-a, mesmo que pelo avesso. A ela junta-se a força apolínea indicada pelo amor sublime e pela escolha das imagens e aspectos formais da peça -, também parte dessa criação. As relações entre as duas forças, que espelham também o encontro entre erudito e popular, marcam a retomada do mito de Orfeu no morro carioca, feita por Vinícius.

${ }^{188}$ Anotações de palestra de Luiz Tatit, realizada no Sesc Santo Amaro. 
No início da edição em livro de Orfeu da conceição, assim como no programa da peça, Vinícius de Moraes faz uma advertência a futuras encenações: "As letras dos sambas constantes na peça, com música de Antônio Carlos Jobim, são necessariamente as que devem ser usadas em cena" [grifo meu]. Quanto aos atores, prefere que sejam apenas atores negros, aceitando, "eventualmente", que o elenco seja composto por atores brancos; ressalta o caráter bastante mutável da linguagem popular, fazendo questão de que se façam as necessárias "adaptações". Até mesmo a ação deveria ser atualizada "o mais possível". Enfim, Vinícius só não admite uma mudança: a das letras dos sambas com a música de Tom Jobim (mais à frente, ele também assinala: "na peça deverá ser tocada, obrigatoriamente, a valsa de Eurídice", de sua autoria). O texto e o contexto poderiam ou mesmo deveriam ser modificados, mas não as canções; como se a expressão delas, diferente das outras, não sofresse a ação significativa do tempo, não carecesse de ser atualizada ou adaptada. Consagrando as canções, Vinícius, premeditadamente ou não, encaminha a efetivação do mito de Orfeu; nas novas montagens da peça, o poder do canto venceria, como de fato venceu, a passagem do tempo e a morte.

Passados mais de quarenta anos depois da criação de Se todos fossem iguais a você (assim como do Tema de Eurídice) e mais de vinte anos depois da morte de Vinícius, esta canção é sempre lembrada, inclusive atravessando o Atlântico como fez, em sentido inverso, o mito do Orfeu grego.

Esta permanência do canto, cuja origem deriva do contato entre o poeta, Vinícius de Moraes e o morro, é, na realidade, em si mesma vitoriosa e soa, ainda e, sobretudo, nos dias de hoje, como lição. 


\section{Outros Orfeus}

Criação textual, tal qual a poesia, o romance ou o teatro, os filmes são derivados de uma série de escolhas, de recortes e do arranjo dessas escolhas, que instauram, a partir do mundo real, seus "mundos possíveis", dotados de significado. $^{189}$

O tema de Orfeu retomado por Vinícius desdobra-se ainda em dois filmes: Orfeu negro, de Marcel Camus e Orfeu, de Carlos Diegues. Nas análises de Orfeu negro e Orfeu serão considerados, como método, os mecanismos e significados imanentes das obras cinematográficas, consideradas também como texto.

As análises seguintes buscam verificar como esse mito, já atualizado por Vinícius de Moraes, revela-se nestes outros dois "mundos possíveis", derivados da peça teatral.

\section{2- "Agora eu sou Orfeu"}

Análise de Orfeu negro, de Marcel Camus

O filme Orfeu negro, de Marcel Camus, estreou em 1958. Ganhou a Palma de Ouro, no Festival de Cannes, em 1959; o Oscar e o Globo de Ouro, como melhor filme estrangeiro, em 1960, assim como foi considerado o melhor filme estrangeiro, pelos Críticos de Cinema de Nova lorque, e melhor filme pela Academia Britânica. Passados quarenta e um anos de sua estréia, em 1999, foi apresentado como obra hors concours, no XXI Festival Del Nuevo Cine Latinoamericano.

${ }^{189}$ Cf: Casetti, Francesco e Di Chio, Federico. Cómo analizar un film. Barcelona/México/Buenos Aires: Paidós, 1996. 
Simmone Jacquemmard e Jacques Brosse, autores de pesquisa cuidadosa sobre Orfeu, mencionam, logo na introdução de seu livro, a repercussão de recente apresentação de Orfeu negro, na televisão francesa. A referência vem como exemplo da qualidade do mito de Orfeu de sempre "fazer parte do imaginário dos homens, sempre novo, desaparecendo e reaparecendo até mesmo onde ele não é esperado: em pleno carnaval do Rio de Janeiro", qualidade também apontada na constatação de J.P. Rosa, citado pelos pesquisadores:

Este filme conheceu um imenso sucesso. Desde sua estréia nas telas, há quase quarenta anos, ele guardou intacto seu poder de sedução sobre todos os diferentes públicos.[...] Assim, os nomes surpreendentes de Orfeu, Eurídice, Hermes, introduzem-nos em um mundo estranho, que transcende o tempo e o espaço, e dentro do qual a Grécia antiga mistura-se sem avisar no carnaval do Rio.[...] Enfim, nenhum detalhe que não tenha sido trabalhado em função da lenda de Orfeu, de maneira não a transportar, mas antes de tudo a torná-la atual, a encarná-la aqui, hoje, em uma cultura, em outro continente. [grifo meu] ${ }^{190}$

Há alguns anos, em um documentário sobre os filmes de Spike Lee, diretor negro norte-americano, um ator recorda como uma das mais belas $\mathrm{e}$ emocionantes cenas vistas por ele em filme, justamente, o final de Orfeu negro feito há 44 anos, é bom lembrar - em que dois meninos sentados olhando o morro após a morte de Orfeu, imitam o herói, fazendo o sol nascer novamente, acompanhados pelo violão.

Além de Orfeu negro, Marcel Camus dirigiu mais dois filmes locados no Brasil: Os Bandeirandes, 1960, cujo roteiro foi escrito pelo próprio diretor, e Otália da Bahia, 1976, baseado na obra de Jorge Amado. O primeiro apresenta a trajetória de um engenheiro francês que, depois de trapaceado por seu sócio em uma mineração, apaixona-se por uma brasileira. As cenas acontecem no Amazonas e depois na recém capital do país, Brasília. O segundo filme é rodado em Salvador. Comum aos filmes é a referência a capitais do Brasil: Rio, Salvador e Brasília, e o registro documental de suas festas populares: o carnaval, em Orfeu; a romaria, em Os Bandeirantes.

${ }^{190}$ Op. cit., p. 9-10. 
Em entrevista ${ }^{191}$, Marcel Camus coloca a preocupação de registrar a ternura, como um de seus principais objetivos ao filmar Orfeu negro. Ao dizer isso, provavelmente sem saber, o diretor francês aproximou-se de Vinícius de Morais. Ambos, embora com duas concepções diferentes de Orfeu da Conceição, (Vinícius chegou revoltado contra a adaptação feita por Camus, abandonou a sala de projeção do filme antes mesmo da sessão terminar) foram tocados sensivelmente pelo que presenciaram no morro. $O$ encantamento do engenheiro francês pelas festas e pessoas ao seu redor, em Os Bandeirantes, cujo roteiro é do próprio Camus, confirma o interesse desse diretor pelo registro, sobretudo, da cultura observada por ele em nosso país.

Análise e interpretação de Orfeu negro, de Marcel Camus.

\section{Seqüência 1}

Do lado direito da tela, os sambistas com roupas coloridas descem o morro tocando o samba em direção à cidade. Vindo do lado oposto, aparecem as lavadeiras equilibrando, aparentemente sem esforço, latas de água na cabeça. Com elas, misturando-se ao batuque, entra em cena a suave canção, afastando pouco a pouco o samba e tornando-se o canto principal a acompanhar as mulheres na subida ao morro. Entre elas, a alegre Serafina, levando água como as outras mulheres, passa alegre entre os outros moradores. As casas são bastante simples, assim como o terreno onde elas estão. As crianças brincam pelos caminhos entre as casas, onde passeiam e brincam também os animais. As mulheres conversam animadas, seja lavando roupas no rio ou mesmo carregando água. Os vários trajetos : dos homens descendo o morro, das mulheres subindo e de Serafina dirigem o nosso olhar, primeiro com closes (meio plano) rápidos, dos homens e das mulheres, sob o ritmo do samba; depois, mais lentos, com a entrada de Serafina, quando a cena se abre em grande angular, ampliando o campo de visão para toda a baía da Guanabara. Entramos no morro pelo olhar do

${ }^{191}$ Sonorama, n. 9. Juin, 1959 (registro sonoro). Biblioteca François Miterrant, Paris. 
autor implícito ${ }^{192}$, como se fosse o nosso, envolvido tanto pelo ritmo do samba, querendo ver tudo de perto rapidamente; quanto da Bossa Nova, que vai chegando devagar, até vermos todo o mar. Como espectadores implícitos, passivos, a sensação chega a ser a de que dirigimos a câmera, morro acima. $O$ uso da grande angular, ampliando o campo de visão das tomadas que acompanham a pipa no céu, provoca a sensação de estarmos diante da realidade, embora saibamos que, como a própria descrição que faço aponta, já esteja recortada aí uma das marcas principais do filme, ou seja, o contraste, expresso pelos movimentos de aproximação e distância, de ritmo rápido e lento, de subida e descida.

Simultâneas, canção e imagens contemplam-se entre si, sob a luz difusa, unindo os personagens do morro e a grandiosidade do céu e do mar sem fim.

Descrito o ambiente, a ação do filme começa no momento em que a câmara, em plano seqüência ${ }^{193}$, acompanha o caminho de Serafina em direção à parte mais alta da favela. Da cidade, chega o som de sirene da balsa, que aparecerá na cena seguinte, trazendo Eurídice. No alto do morro, a amiga e protetora do casal protagonista encontra as duas crianças: Benedito e Zeca. $\mathrm{O}$ primeiro chama sua atenção para o vôo da pipa, no céu. $O$ encantamento dela chega e vai embora com a mesma rapidez: sem vento, o brinquedo em forma de "sol" começa a cair exigindo a destreza do menino, para que continue no ar.

A canção "A felicidade", de Vinícius de Moraes e Antonio Carlos Jobim, acompanha a cena, ressoando e resignificando, em sua letra, a imagem que vemos na tela: "A felicidade é como a pluma/ que o vento vai levando pelo ar/ Voa tão leve/ Mas tem a vida breve/ Precisa que haja vento pra voar".

\section{Seqüência 2}

\footnotetext{
192 O "autor implícito " é um termo usado para definir a "figura abstrata" que representa "las actitudes, las intenciones, el modo de hacer etc del responsable del film". Casetti, Francesco e Di chio, Federico. Op. cit., 226.

193 Um dos tipos de associação entre as imagens dos filmes. "El plano-secuencia. Consiste en 'una toma en continuidad' : todos los distintos momentos que componen una secuencia son incluidos en un solo encuadre". Idem, p. 108.
} 
A balsa chega à cidade como um bloco carnavalesco, entrando pelas ruas. Eurídice desce e vai percorrendo as ruas e avenidas até o aparecimento do bonde e seu encontro com Orfeu.

Nas cenas iniciais, privilegia-se o campo/contra ${ }^{194}$ campo, ora focalizando Eurídice, ora o que está à sua frente; há certo constrangimento entre a personagem e o que ela vê. Primeiro, ela assusta-se ao esbarrar em um cego, que termina por indicar-Ihe o caminho que procura. Depois, ao lado da representação do carnaval, vinda pelas máscaras entre divertidas e algo assustadoras dos vendedores, juntam-se as carnes de animais penduradas pelas mãos dos vendedores (há também a imagem de pássaros presos numa gaiola), tomando de repente o olhar da jovem. Nesses momentos rápidos, o nosso olhar identifica-se ao de Eurídice, colocando-nos como recém chegados à grande cidade. A seqüência fecha-se com o cerco final dos vendedores e carnavalescos em volta dela, que "escapa" com alguma ajuda.

Depois de todo esse movimento acompanhado bem de perto pelo carnaval, com música e máscaras, Eurídice anda entre os arranha-céus, pelas ruas com poucas marcas da festa - alguma serpentina e quase mais nada. A cena, filmada de cima para baixo, faz sobressair a magnitude do conjunto de prédios frente à solidão e o tamanho pequenino de Eurídice, acentuados ainda mais pelo distanciamento ainda maior da música, que vinha acompanhando as imagens animadas pelo carnaval.

Um bonde repleto de pessoas que também comemoram, em bloco, o carnaval, passa por Eurídice, que é pega pela cintura e, como numa brincadeira de criança, deixa-se levar para dentro do veículo. Pouco depois, Orfeu, trocador do bonde, dirige seu olhar não para os grandes prédios modernos da cidade, mas para a parte antiga que provoca sua admiração. Logo depois, o veículo atravessa 0 antigo aqueduto.

\footnotetext{
194 "campo/contra campo" corresponde à "Asociación por proximidad. [...]. Entre las imágenes $A$ y $B$ se viene pues, a instaurar um nexo del tipo "A-B" [...] (A: alguién que mira; $B$ : el objeto visto)" . Idem, p. 107-8.
} 
Esta última cena, filmada de baixo para cima, acentua a importância e o distanciamento do veículo a caminho do alto do morro, deixando a cidade para trás e sinalizando outra oposição: morro x cidade.

\section{Seqüências 3 e 4}

O contraste entre o morro e a cidade, cifrados entre o alto e o baixo, respectivamente, continua nas seqüências da chegada do bonde que traz Eurídice e Orfeu: depois de encontrar Hermes, que Ihe indica a casa de Serafina, Eurídice caminha para o alto do morro ao passo que Orfeu, encontrando Mira, volta para a cidade para retirar seu violão do prego - conforme seu maior desejo -, e marcar seu casamento com Mira -, conforme o desejo dela.

Com máscara de carnaval, entusiasmado, o funcionário do cartório remete Orfeu a "seu" mito: "todos sabem, Orfeu ama Eurídice". Contestado pelos fatos a noiva presente é Mira - ele explica, desapontado e a contragosto, o seu comentário: "é apenas uma velha história".

As fantasias vão sendo retiradas do penhor, ganhando as ruas como 0 violão de Orfeu, ao mesmo tempo em que guarda-chuvas vão sendo penhorados.

É digno de nota, ainda nessa seqüência, o desprendimento e pressa do rapaz que, depois de vender a Orfeu, de maneira confusa, o gramofone rejeitado pelo penhor, transforma o bocal do aparelho em seu instrumento de sopro e de integração ao som do carnaval que passa pela avenida.

\section{Seqüência 5}

Orfeu sobe o morro com Mira. Numa manobra de Serafina, ele consegue fugir da noiva, deslumbrada enquanto mostra para o grupo de mulheres que a rodeiam o anel de noivado, "quase" de brilhante verdadeiro. No alto do morro, em seu barraco, Orfeu afina o violão ao lado das crianças que o questionam sobre sua capacidade de "fazer o sol nascer". A confirmação, como o comentário do 
funcionário do cartório, também traz do passado a história que continua. No momento, ele é quem tem como mestre Orfeu. "Agora, Orfeu sou eu”, declara o músico, assumindo o seu lugar na passagem do tempo.

Fugindo das ex-namoradas, ele refugia-se no barraco vizinho ao seu. Lá, encontra Eurídice. A referência ao mito volta, agora pelo comentário de Orfeu, repetindo o que ouvira do funcionário público sobre uma "velha história": "Orfeu ama Eurídice". Os dois entristecem. Na varanda, a proximidade entre o casal apaixonado e a paisagem de fundo é acentuada pelo foco comum e o uso da grande angular, que amplia o campo visual, integrando ainda mais Orfeu, Eurídice e a natureza ao seu redor. Um avião atravessa o céu que por um momento escurece, como o início de um crepúsculo, acentuando o tom melancólico do casal, quando este parece relembrar a sua "velha história".

Seqüências 6,7,8

No ensaio da escola de samba, à noite, os dois dançam ao olhar dos outros moradores do morro. Os close-ups de Orfeu e Eurídice revezam-se com as tomadas dos outros personagens sambando, com close-ups de seus pés calçados com alpargatas simples, acompanhando o ritmo do samba.

Bentinho, machucado na testa, avisa sobre o homem que procura Eurídice. Amedrontada, ela foge. Mira percebe o interesse de Orfeu e tenta, sem sucesso, impedi-lo de socorrer a moça.

A perseguição acontece na parte mais baixa do morro, próxima ao precipício. Vencido momentaneamente o embate entre Orfeu e o perseguidor, o músico sobe o morro carregando Eurídice, desmaiada, até o barraco de Serafina.

Novamente temos a oposição entre o alto, o barraco no morro, e o baixo, 0 precipício, onde Orfeu luta contra o homem fantasiado de caveira. 


\section{Seqüência 9}

Ao amanhecer, ao lado de Eurídice, Orfeu faz o sol nascer com o violão trazido às escondidas pelas duas crianças. É o dia do desfile. Depois que o casal se despede, Mira chega; desconfiada termina por brigar com o músico sem que ele possa esclarecer a nova situação. Todos descem para a cidade. As crianças acompanham Orfeu, que leva o estandarte do sol para o desfile. Eurídice aceita a sugestão de Serafina: veste a fantasia da prima, de Rainha da Noite, e desce para o desfile na cidade junto a Orfeu e as crianças, sem ser reconhecida pelos outros moradores do morro.

O olhar panorâmico, em foco, aproxima novamente montanhas, mar e o morro, intensificando a unidade entre os três, determinada também pela música tema que acompanha os personagens até o desfile: "o nosso amor vai ser assim/ Eu pra você/ Você pra mim//Tristeza, eu não quero nunca mais/Vou fazer você feliz/ Vou querer viver em paz/ O destino é quem me diz".

\section{Seqüência 10 a 13}

A noite vai chegando. A escola de samba Unidos da Portela passa; já não há mais a luz do sol. É noite. As imagens da escola de Orfeu, Unidos da Babilônia, que começa a se organizar para entrar na avenida, são recortadas pela sirene e passagem de guardas, tensionando as cenas que em ritmo acelerado, como o do carnaval que se mostra, vão anunciando a morte próxima de Eurídice.

As alpargatas e as roupas simples do ensaio, da noite anterior no morro, dão lugar ao brilho das roupas e dos sapatos que relembram o Brasil colonial. A roda de samba transforma-se em desfile pela avenida.

Bentinho passa entre os passistas da escola. A câmera abaixa, como se fosse ele que a segurasse. Dessa forma, a impressão resultante é que vamos passando junto com ele entre as pernas dos carnavalescos.

Orfeu é chamado para receber os cumprimentos do júri. A figa oferecida por Benedito a Eurídice cai do pescoço dela. O menino tenta recuperá-la, mas antes 
disso o amuleto é esmagado por um dos guardas, pressagiando a tragédia que se aproxima ainda mais. Eurídice avista o homem que a persegue e também é descoberta por Mira, que vai de encontro a ela. Eurídice tenta fugir chamando Orfeu.

\section{Seqüência 14}

O momento fatal da perseguição ocorre na garagem dos bondes. Recuperando o mito, Eurídice morre por causa de Orfeu. Ironicamente, a luz elétrica acionada por ele mata a moça. O barulho de sirene que entremeava 0 desfile da escola de Orfeu reaparece agora com a ambulância.

A tragédia de Orfeu coincide com o fim do carnaval. Foliões bêbados, desmaiados, outros machucados, outros sendo presos, fantasias rasgadas. $O$ sofrimento do músico é desdenhado. A cena do guarda, que o reconhece e pede para que cante ou mostre o seu passo de samba, é exemplar do desprezo pelo sofrimento do músico.

A indiferença ganha corpo ainda maior no contraponto entre o desespero de Orfeu e o espaço vazio e escuro do enorme prédio institucional com salas repletas de papéis e papéis, tão sem sentido como os andares e escadas que vão levando para baixo, em espiral, a lugar nenhum. O ponto mais alto aonde vai Orfeu, na cidade, o $12^{\circ}$ andar do prédio, confronta-se, assim, com o ponto mais alto do morro, ou seja, a morada de Orfeu.

Se antes percebíamos a grande dimensão dos arranha-céus pelo contraste entre a visão dos prédios e a travessia de Eurídice entre eles - claramente expressa pelo "autor implícito"195 -, a grandiosidade do prédio, no qual Orfeu entra à procura de Eurídice e só encontra papéis, será observada, desta vez, pelo olhar

195 O "autor implícito " é um termo usado para definir a "figura abstrata" que representa "las actitudes, las intenciones, el modo de hacer etc del responsable del film". Idem p. 226. 
de Benedito, antes mesmo de Orfeu passar pelos corredores vazios e encontrar o senhor que tentará levá-lo até Eurídice, na seção do candomblé.

Desconsolado, o músico procura Eurídice no hospital, no prédio dos desaparecidos até chegar ao candomblé. Depois de, sem ânimo algum, sair da cerimônia, onde por um momento pensa ter finalmente encontrado Eurídice, ainda durante a noite, Orfeu é encontrado desmaiado por Hermes e Benedito. Finalmente, depois de encontrar Eurídice, o músico volta para o morro. A declaração de amor vem novamente como da primeira vez em que carregava a moça, embora, neste momento, ela esteja morta. O sol acompanha o casal. Outra vez, o olhar da câmera é panorâmico, reintegrando os dois personagens à bela paisagem à qual se juntam as últimas falas e o canto de Orfeu ainda mais triste: "A felicidade do pobre parece/ a grande ilusão do carnaval/ a gente trabalha...".

A favela está em chamas e é dela que parte a pedra jogada por Mira que atinge Orfeu, resultando em sua queda junto a Eurídice, no precipício.

Vivenciando o mito narrado por Orfeu às crianças, Zeca, agora, é o dono do violão que faz o sol nascer e o morro, - representado pela pequena menina -, dançar novamente, sugerindo a permanência de Orfeu pela música.

Fazendo o sol nascer novamente

A primeira imagem de Orfeu negro, vinda em travelling ${ }^{196}$, é a de bustos esculpidos na parede, que lembram os deuses gregos; imagem em preto e branco, acompanhada de música instrumental em que predomina a melodia. $A$ música sinaliza Dionísio, as esculturas, Apolo. Juntas, reportam-nos à Grécia

\footnotetext{
${ }^{196}$ No travelling "es la cámara, y no el personage con su desplazamento el eje de su mirada,quién decide lo que se debe ver: retrocede a partir de un detalle y encuadra, ampliando su campo de acción, objetos imprevistos, recorre el espacio mediante lentos travellings mostrandonos poco a poco lo que podría darnos en su totalidad y de una sola mirada". Idem, p. 146.
} 
antiga, e, naturalmente a Orfeu. Preenchendo toda a tela, temos aí o ponto de partida do filme, logo quebrado pelo ritmo bem marcado da batucada do morro ${ }^{197}$, tomando a tela colorida com os entusiasmados sambistas descendo em direção à cidade, enquanto as mulheres vão subindo o morro.

Os vários contrapontos aí presentes entre o antigo e o novo, a cultura grega e a do Brasil, a melodia e o ritmo, o descer e subir sinalizam o movimento geral do filme de Camus que se desdobrará em outras oposições como alto e baixo, proximidade e distância, felicidade e tristeza, morro e cidade e, finalmente, vida e morte.

Logo nas primeiras cenas, durante a abertura dos enquadramentos, que partem do corte em close dos sambistas até a imensidão de céu e mar atravessada pela pipa/sol, tudo se mostra como se não houvesse mediação alguma; aquela realidade, ou o que é colocado como realidade, vem até nós, efetivando-se em sua projeção. Nas cenas, tanto o que está em primeiro plano (a pipa amarela, que lembra o sol, controlada por Zeca, por exemplo), como o que está mais ao fundo (os montes e a baía), ambos em foco, ressaltam a unidade entre favela, céu e mar, fazendo sobressair, na seqüência, o caráter idílico vivenciado no morro; o ambiente aproxima-se mais da imagem que temos do meio rural distante do morro, do que da cidade a seus pés.

A impressão agradável do morro, naturalmente, está mais próxima daquela de Orfeu da Conceição do que a da opinião pública registrada pelos jornais da época, em que as favelas eram identificadas aos cortiços, tidos como "inferno social". Mesmo assim, o caminho de Marcel Camus, em seu Orfeu negro, difere bastante daquele escolhido pelo poeta.

Depois de tentar várias portas, que fossem elos entre as duas obras, escolhi esta que me parece a mais favorável, entre outros motivos, para percebermos como Orfeu se realiza nestas duas tomadas: do poeta e do cineasta. Proponho começarmos pela canção.

197 Ou que se abre para que o ritmo entre na tela. 
Felicidade e tristeza

Até o momento em que o brinquedo das crianças, a pipa amarela em forma de sol, ameaça cair por falta de vento, nada parece abalar a felicidade que se apresenta no morro, mas, simultaneamente, música e imagem informam sobre a brevidade da felicidade contraposta ao longo tempo triste. A imagem, além de figurar a necessidade de vento para que a pipa continue no ar, figura também o conteúdo genérico da canção que a acompanha - a felicidade do pobre que "precisa que haja vento pra voar" - e, ao mesmo tempo, prefigura a tragédia particular a ser vivenciada por Orfeu e Eurídice.

A suspensão do vento, prenunciando a tragédia de Eurídice, faz lembrar os ruídos da natureza, em Orfeu da Conceição, portadores desta mesma função. A cena cumpre, no filme, a mesma função do soneto de Corifeu, na peça, prenunciando a tragédia final. Mas enquanto o soneto frisa o sofrimento por amor, de todos aqueles que "têm paixão", o canto traz consigo a referência direta à questão social que só aparece de forma explícita, como vimos, no final de Orfeu da Conceição, nos comentários dos moradores do morro:

Tristeza não tem fim
Felicidade sim
[...]
A felicidade do pobre parece
A grande ilusão do carnaval
A gente trabalha o ano inteiro
Por um momento de sonho
pra fazer a fantasia
de rei ou de pirata ou jardineira
pra tudo se acabar na quarta-feira $[\ldots]]^{198}$

Corifeu:

São demais os perigos dessa vida,

198 Moraes, Vinícius de. e Jobim, Antonio Carlos. Cancioneiro Vinícius de Moraes: Orfeu: songbook/ músicas de Antonio Carlos Jobim \& Vinícius de Moraes. Op. cit.,p. 181. 
Para quem tem amor, principalmente

Quando uma lua surge de repente

E se deixa no céu, como esquecida.

E se ao luar que atua desvairado

Vem se unir uma música qualquer

Aí então é preciso ter cuidado

Porque deve andar perto uma mulher.

Deve andar perto uma mulher que é feita

De música, luar e sentimento

E que a vida não quer de tão perfeita.

Uma mulher que é como a própria Lua:

Tão linda que só espalha sofrimento

Tão cheia de pudor que vive nua.. ${ }^{199}$

Atravessando a canção, a sirene, vinda da balsa que chega à cidade trazendo Eurídice, termina por adentrar e logo a imagem da cidade substitui a do morro.

O antigo e o novo

O olhar de Orfeu e de Eurídice

O contraponto entre "felicidade e tristeza", quase despercebido em meio à beleza natural do morro, é seguido pelo contraponto entre o antigo e o novo. Como bem observa o crítico Tunico Amâncio:

O filme evoca em seu início a constituição da cidade, a entrada pelo centro histórico - a Praça XV, [...] os arcos da Lapa, a Cinelândia: uma cidade pulsante, cheia de atividades, vendedores e representantes de várias profissões, gente dançando, travellings reveladores. E logo como contraponto temos, uma delicada sinalização para o futuro, representado pelo Prédio do Antigo Ministério de Educação e Saúde, o edifício Capanema, a mais completa modernidade arquitetônica, criada por Lúcio Costa, supervisionada pelo próprio Corbusier e inaugurada em

${ }^{199}$ Moraes, Vinícius. Orfeu da Conceição. Op. cit., p. 402-3. 
1945. Uma breve passagem que nos confronta com a viagem iconográfica pelo passado pomposo, numa seqüência em movimento, onde vamos nos deparar com Orfeu, na boléia de um bonde, que vai seqüestrar Eurídice e iniciar com ela a história trágico-romântica da narrativa. [...] O bonde é, definitivamente, enquanto transporte, um veículo em extinção.

Mas é o bonde que vai levar os futuros amantes pelos Arcos da Lapa [... ${ }^{200}$

Esse contraponto encontrado na cidade se expressa pelos diferentes personagens que vão guiando o nosso olhar de espectadores. Eurídice, em seu percurso, apresenta-nos esse convívio desde o momento de sua chegada, quando sai da antiga balsa, passando pelo centro histórico, onde os carnavalescos se divertem, e entre os prédios, afastados do carnaval, até encontrar o bonde e Orfeu. A grandiosidade dos prédios é evidenciada pelo olhar autoral dirigido aos arranha-céus vistos de baixo para cima, evidenciando a travessia solitária, diminuta e silenciosa de Eurídice entre as enormes construções.

No percurso, entre o antigo e o novo, observamos ainda a inquietude da moça vinda da roça, identificando-nos a ela, sobretudo, nas cenas de campo/contra-campo, quando ora vemos Eurídice, ora o que ela observa: vendedores expondo os animais mortos postos à venda ou outras mercadorias, cercando-a e impedindo seu percurso ${ }^{201}$.

O olhar de Orfeu, no início do filme, momentos antes do bonde seguir em direção ao morro, é dirigido não aos novos prédios altos, mas às construções antigas admiradas pelo cantor, enquanto o veículo, símbolo também de um tempo

\footnotetext{
200 Amâncio, Tunico. "O estrangeiro Marcel Camus: olhares do afeto sobre algumas cidades brasileiras", in: Passages de Paris 1 (2005) p. 56. www.apebfr.org/passagesdeparis

${ }^{201}$ A sensação de temor sugerida pelo cerco, no momento em que Eurídice passa pela cidade, repetir-se-á, quando Eurídice, tentando fugir de Mira, é presa pela serpentina atirada nela por seu perseguidor, sinalizando o desfecho trágico já anunciado pelo primeiro cerco dos vendedores $\mathrm{e}$ carnavalescos.
} 
antigo, passa pelo aqueduto construído no século passado e transformado em linha para o bonde ${ }^{202}$, já também em vias de extinção ${ }^{203}$.

No filme de Camus, a atualização do mito é deliberadamente marcada. Orfeu e Eurídice, assim como o funcionário do cartório e Hermes (personagens acrescidos ao filme) aludem claramente ao mito: aquela "velha história". A lembrança traz tristeza à expressão do casal, mas não impede de ficarem novamente juntos, repetindo o mito, agora no morro.

O morro e a cidade

O olhar de Benedito

A oposição marcada na cidade entre o antigo e o novo - o primeiro representado pelas construções antigas, a balsa, o bonde e pelo antigo aqueduto, transformado em linha para o bonde, e o segundo representado, principalmente, pelos arranha-céus -, dialoga com a retomada do mito de Orfeu e Eurídice, prolongando-se em um outro contraste, que também perpassa o filme: entre o morro e a cidade. Ao antigo, na cidade, parece corresponder a retomada do mito de Orfeu, "a velha história".

Grande parte das cenas diurnas ocorrem no morro, que por sua vez, em praticamente todas as tomadas, integra-se totalmente à natureza do céu e do mar. Natureza que envolve ainda o amor de Orfeu e Eurídice, assim como as crianças, sobretudo no final, e os pequenos animais que convivem harmoniosamente na morada de Orfeu, diferentemente do que ocorre com os animais na cidade, onde, mortos, vão sendo expostos pelo comércio, ou aparecem presos numa gaiola.

\footnotetext{
${ }^{202}$ Arcos da Lapa "um dos principais símbolos da cidade do Rio de Janeiro, o Aqueduto da carioca, popularmente conhecido como Arcos da Lapa, é considerada a mais importante obra do Rio Colonial construído em 1723 para levar as águas do rio Carioca até o largo da Carioca, sanando o problema de água na cidade. /A água abastecia o famoso chafariz do Largo da Carioca, que passou a ser ponto de encontro de escravos e mercantes e centro de vida urbana da época. www.lanalapa.com.br /estabelecimentoDetalhe.asp.

${ }^{203}$ Como salienta Tunico Amâncio, "Curiosamente, em 1059, ano de Orfeu, é o ano de grandes novidades para a indústria automobilística: é quando vai para as ruas o primeiro 'Fusca', é lançado o 'Dauphine', com licença da Renault, assim como o Simca Chambord e o luxuoso 'Fenemê JK4, com licença da Alfa Romeo". Op.cit.,p.53. [apud. Nosso Século. Abril Cultural, 1980, v.4 $1945 / 1960$ p.214.
} 
Tanto na peça quanto no filme, existe uma associação entre a cidade e o inferno, mas enquanto, na peça, as referências a ela concentram-se nos comentários dos moradores da favela e no carnaval do "Clube dos maiorais" para onde Orfeu se dirige procurando Eurídice, e de onde sai sem ela -, em Orfeu negro é na cidade que Eurídice é perseguida e nela finalmente é morta. É na cidade que, apesar da alegria do carnaval, os bens são penhorados. Nela se encontram, ou melhor, não se encontram os desaparecidos. Lá, a sirene toma o lugar do canto e os policiais controlam a festa e desconsideram as pessoas; na cidade, a luz elétrica substitui a lamparina dos barracos, mas mata Eurídice.

Orfeu leva o sol do morro para a cidade e dela traz Eurídice morta, a paixão concretiza-se no morro e morre na cidade. O canto de Orfeu nasce de seu encontro com Eurídice, no morro, cercado pela natureza que se abre aos olhos a partir deste lugar. Depois da morte de Eurídice seu olhar na cidade está totalmente perdido na noite, só voltando a ganhar vida, quando Orfeu sobe o morro, carregando a moça, novamente admirando e agradecendo a linda e calma paisagem vista por ele, ao mesmo tempo em que vai nascendo a manhã, novamente, depois da longa noite, como se Eurídice estivesse viva.

Semelhante ao que ocorre na peça, o morro é desprezado pela cidade, no filme de Camus. Os moradores do morro também estão integrados à natureza e vivem em comunidade, contrariando, a seu modo, o discurso corrente sobre as favelas, na época em que o filme foi realizado.

Como na peça, a identidade entre o músico e o sol, e, por extensão, o morro é evidente: seu canto "faz o sol nascer", no morro; no desfile, ele é o "Rei do Dia", quando representa a escola de samba do morro; é ele quem leva o estandarte/sol acompanhado pelas crianças. O primeiro encontro com Eurídice e os últimos momentos com ela, depois de sua longa procura noturna, ocorrem de dia.

Já as ameaças contra o casal acontecem nas noites do ensaio e do desfile. A morte de Eurídice também acontecerá, na cidade, à noite. Retoma-se, assim, a peça, em que a morte é representada pela Dama Negra, que também surge à noite. 
Assim podemos associar Orfeu/sol à vida, em oposição à morte/noite.

É interessante, partindo dessa relação, lembrar da cena em que vários guarda-chuvas vão sendo penhorados, na medida em que as fantasias vão saindo do penhor (ganhando a rua como o violão de Orfeu), sugerindo a parada do "ano inteiro" de trabalho" associada ao aparecimento do sol.

O penhor dos guarda-chuvas faz lembrar, novamente, agora por oposição, da pipa amarela em formato de sol, do início do filme, e do estandarte/sol que, por sua vez, reaparece, rapidamente, depois da chegada de Eurídice ao fim da linha do bonde, e quando é levado do morro por Orfeu e pelas crianças para o desfile das escolas de samba, na cidade. O sol perpassa o filme e, em relação ao penhor, marca a oposição entre o tempo ruim do trabalho, associado à chuva, e o tempo bom, solar, trazido por Orfeu.

A cena é metáfora da canção tema do filme, "A felicidade", que anunciava já no início, o tempo curto da felicidade em oposição ao da tristeza, relacionado também à vida dos pobres. Diferentemente da peça, a referência à questão social apontada por essa canção percorre o filme, como se verifica na cena em que os guarda-chuvas vão sendo penhorados, como também no contraponto entre as roupas e sapatos dos moradores do morro - à noite no ensaio e no desfile na avenida ; na falta de dinheiro porque se gastou "tudo na fantasia" (como explica Serafina, desculpando-se por não ter comida em sua casa) etc.... Diferentemente da peça, a referência direta aos pobres vai acompanhando a história de Orfeu e Eurídice, seja pelas imagens ou pelas canções.

A canção $A$ felicidade abre e fecha Orfeu negro. Uma segunda canção percorre o filme de Camus. Se por um lado, a primeira canção pontua o contraponto entre a felicidade e a tristeza, que se desdobra de alguma forma nas oposições entre o novo e o moderno e entre a cidade e o morro; por outro, a segunda canção traz com ela a alegria solar, de Orfeu, deslocando a tristeza, que vai sendo trazida pelo enredo do filme: "Tristeza, eu não quero nunca mais [...]o destino é quem diz eu pra você pra mim..." 
Outro olhar bastante significativo é o de Benedito. Ele, mais do que Zeca, representa a cultura negra sobretudo por sua crença; é ele que, querendo proteger Eurídice, dá a ela a figa - amuleto, bastante popular da cultura africana-, e tenta recuperá-la, quando esta cai do pescoço da jovem, momentos antes de ela começar a ser perseguida; é ele quem pressente o perigo aproximando-se de Eurídice e quem comenta sobre a morte. Durante o périplo angustiado de Orfeu, Benedito tenta acompanha-lo. Seu nome é o mesmo do santo católico negro, o que aponta também para o sincretismo entre o culto africano e a religião católica. É ele que se deslumbra com o poder de Orfeu de fazer o sol nascer com seu canto e que promove o prosseguimento disso ; é também ele quem tenta proteger Eurídice; ou seja, Benedito é o condutor do renascimento do canto que traz a luz do sol de volta ao morro. É ele quem dirige o olhar de Serafina e o nosso para a pipa/sol enquanto ela sobe no céu, mesmo que precisando que haja vento para continuar voando. É ele, finalmente, quem nos indica, em contraponto, a imensidão do prédio indiferente à dor de Orfeu.

É justamente o antigo na cidade - suas construções, o bonde, a marchinha de Carnaval - que se identifica a Orfeu , ou seja, ao que ele representa em termos de lembrança de um outro tempo, ameaçado pelo novo, por uma modernidade que pode sombrear as pessoas, transformando-as em papéis sem valor, sem histórias, sem as velhas histórias, que se infiltram, apenas como exceção, por aqueles que ainda são capazes de fantasiar, como o funcionário que experimenta a máscara de carnaval, no trabalho, e remete-nos ao mito de Orfeu.

Os olhares de Eurídice, de Orfeu e de Benedito descortinam esses dois mundos. O primeiro, solar/apolíneo, aparece identificado, sobretudo, à intimidade idílica, provedora entre homem e natureza, entre homem, sua dança e seu canto, onde o amor antigo volta a acontecer; e o segundo relaciona-se à modernidade, que acena com o arranha-céu, isolado da festa, e ao caminho cruel enfrentado por Orfeu, o caminho da burocracia, onde não é possível encontrar os desaparecidos; das instituições, que desconsideram as pessoas; das sirenes, que 
atravessam o canto carnavalesco, juntando-se ao fim do carnaval; da luz elétrica que mata Eurídice ${ }^{204}$.

Ao mesmo tempo que conduz o renascimento do canto solar, Benedito está ao lado da "velha história" que volta, agora no morro. Seu olhar acompanha o percurso de Orfeu e Eurídice durante todo o filme, até mesmo antes de eles aparecerem, quando o menino observa a pipa precisando de vento para voar. Seu olhar participa tanto da alegria do ensaio do samba no morro e sua beleza, quanto das ameaças e sofrimentos pelos quais Orfeu e Eurídice passam. Seu olhar está em sintonia com o deles e graças a isso o canto de Orfeu renasce no morro: é justamente Benedito, quem incentiva, Zeca, o mais novo Orfeu a fazer o sol nascer, como antes. Benedito, dessa forma, toma o lugar da inspiração que continua o canto imortal.

\section{As crianças}

As crianças aparecem na peça de Vinícius, mas apenas no final dela. Em Orfeu negro, elas iniciam e fecham o filme, fazendo nascer o sol novamente com a canção, transformando a tragédia de Orfeu. É como se Camus visse nelas a expressão maior do mito: a capacidade de, renovando-se a cada retomada, (a cada novo Orfeu) continuar tendo o que dizer; e no caso específico desse mito: a

\footnotetext{
${ }^{204}$ Tunico Amâncio, com acerto, distingue o morro, como a cidade alta e a cidade, como a cidade baixa, evidenciando-os como integrantes da cidade do Rio de Janeiro, situação sempre escamoteada, que serviu para a inércia das instituições públicas no sentido de estender seus programas sociais ao morro. $\mathrm{Na}$ análise que faço, preferi manter a distinção por causa do contraponto que faço com a peça de Vinícius. Vale transcrever ainda a descrição da cidade, vista por Camus, aos olhos do crítico: "os cenários onde vai se desenvolver a história de amor, na cidade [...] são os templos da burocracia, os equipamentos de segurança e de saúde, as usinas de reparo dos bondes, eletrificada e de tons teatrais, é o túnel que ratifica a passagem de um mundo a outro, é o hospital, o camburão, o elevador claustrofóbico, os 15 andares cheios de papel, templo da burocracia, o centro de macumba onde Orfeu ousa olhar para trás e condena Eurídice a seu congelamento na eternidade. E, finalmente é o frio necrotério onde o herói encontra sua heroína morta e a leva nos braços. Cenários de desolação, cenários de tragédia, cenários de ruínas. A cidade do Rio de Janeiro morre no Silêncio de Orfeu. Só o morro resplandece, embora cenário também de uma tragédia". Amâncio, Tunico. "O estrangeiro Marcel Camus: olhares do afeto sobre algumas cidades brasileiras". In: Passages de Paris (2005), www.apebfr.org/passagesdeparis, p. 57.
} 
capacidade de transformar a dor em harmonia - signo talvez de uma força nata singular.

As crianças assumem nesta adaptação uma importância maior. Elas transformam o tom trágico final e fazem a situação idílica do início retornar ao morro. Aliás, a figura do homem/morte fantasiado de esqueleto e os sustos provocados em Eurídice pelos vendedores de animais, se, a princípio, parecem deslocados ou pouco convincentes, vistos pelo prisma do olhar infantil, recuperam a alegria lúdica do carnaval, com suas máscaras de bruxas ou de monstros, impressas em papelão, tentando assustar quem está por perto.

A passagem do violão de Orfeu para Zeca, repetindo a experiência do músico, contada por ele mesmo às crianças, sinaliza o vínculo entre a renovação do canto e a capacidade ingênua do olhar infantil, "idade de ouro", capaz de fantasiar; como vemos (num outro extremo?) acontecer na reação natural do velho e matreiro senhor negro e pobre que, colocando seu chapéu real - recém-saído do prego, como o restante da sua fantasia que carrega no braço -, corrige, sem hesitação alguma, o comentário de Orfeu - "Vai ficar bonito como um rei" - : "Eu sou rei!".

Talvez Benedito, representante da raça negra do Brasil, seu encantamento e seus presságios, seja, para Marcel Camus, aquele vento que faz o morro continuar a fazer canções apesar de todas as adversidades, ou que torna o morro capaz de transformar as adversidades em canções. Visto desta forma, é revelador observar a figura de Zeca, ou seja, do novo Orfeu, cuja capacidade de transformar o desejo de Benedito em realidade vem à tona, quando empina o papagaio para a admiração do amigo ${ }^{205}$ e, principalmente, é claro, quando consegue fazer o sol nascer novamente, com seu violão.

Lembrando que as canções do filme são resultado extra-diegético da integração entre os poetas do morro e os poetas da cidade, que resultou na Bossa Nova, a figura desse novo Orfeu, mais claro que Benedito, marcando assim

${ }^{205}$ Que por sua vez nos convida a participar do grande feito. 
a miscigenação das raças no Brasil, aponta também para o sucesso deste olhar do poeta branco da cidade em direção ao morro e à cultura produzida nele, sublinhando neste aspecto não a oposição negativa entre a cidade e o morro, mas uma síntese artística potente desse convívio.

Fechando a última cena, volta, inteira, a figura grega que, antes, quebrando-se $e^{206}$ iniciava o filme, como se a história a que assistimos, só aparentemente, representasse o rompimento com aquela harmonia e beleza gregas; como se elas já contivessem em si mesmas o que estava por existir; depois de tanto tempo e tão longe da Grécia; como se a esperada vitória do canto, apesar da tragédia, reintegrasse a figura.

\footnotetext{
${ }^{206}$ A quebra da figura grega também pode indicar uma referência ao filme de Jean Cocteau sobre Orfeu cujo espelho representa a passagem entre o mundo dos vivos e o mundo dos mortos, usada pela Morte.
} 


\section{3- O Rei do Carnaval}

Análise de Orfeu, de Carlos Diegues

É ponto pacífico nas entrevistas de Carlos Diegues sobre Orfeu, a sua diferença frente à adaptação anterior, o Orfeu negro, de Camus. Segundo o diretor, não se trata de remake. Distante disso, o novo filme viria corrigir a equivocada primeira versão cinematográfica da peça de Vinícius de Moraes.

O sonho de Diegues, desperto na estréia do Orfeu da Conceição, no Teatro Municipal do Rio, quando ainda era adolescente, efetiva-se muitos anos mais tarde, depois, inclusive, do período do Cinema Novo, movimento cinematográfico declaradamente voltado para a exposição crítica dos problemas sociais enfrentados no Brasil, do qual Carlos Diegues foi um dos criadores.

Em 1980, Vinícius começou a trabalhar com o cineasta na criação de um novo roteiro, mas a morte do poeta, ainda no mesmo ano, adiou o projeto do diretor. Somente depois de quase quarenta anos da estréia de Orfeu da Conceição e de Orfeu negro, "chega a vez", lembrando a frase do Orfeu, de Camus, do Orfeu da "Unidos do Morro da Carioca".

Apesar de não ser um remake, o roteiro de Orfeu, de Carlos Diegues guarda algumas semelhanças em relação a Orfeu negro, de Marcel Camus. Eurídice também chega de outra cidade, no sábado de Carnaval, e fica na casa de uma parente sua. Crianças também chamam Orfeu para "fazer o sol nascer" e Mira provoca novamente a morte dele. Outra vez a morada do cantor está na parte mais alta do morro.

Nessa segunda adaptação, Eurídice, filha de um minerador assassinado por causa do comércio de diamantes, chega do Acre, que "é Acre mesmo e não Amazonas", afinal, "Acre é Acre e Amazonas é Amazonas"; região do "boto vermelho" e não do "rosa". Agora é a criança ruiva, "o Russo", e não mais o menino negro, Benedito, quem convida os amiguinhos para ver o sol nascer, ou melhor, nessa versão, para comprovar que Orfeu faz o sol nascer.

Enquanto no filme de Camus, o músico recebe das crianças, sutil e delicadamente, o violão e faz "o sol nascer", no filme de Diegues, ele faz isso pela 
insistência das crianças - cuja expressão a todo momento é corrigida pelo músico: "não é 'Orfeo' é 'Orfeu'” - e como resposta à descrença desdenhosa da garotinha: "Ele 'tá de onda".

O nascimento do sol, no Orfeu de Camus, é extensão dos momentos de amor com Eurídice e reafirma a unidade entre o cantor e a natureza, comunhão da qual as crianças fazem parte; o outro, da abertura do Orfeu de Diegues, vem como prova da capacidade do músico, confirmada pelos aplausos das crianças. Orfeu aproxima-se novamente da natureza, mas a gratuidade anterior é transformada. $O$ nascimento do sol torna-se espetáculo, talvez para evidenciar o caráter diferenciado desse momento, apartado de toda violência que se seguirá na favela.

Enquanto as crianças do filme de Camus, dançando ao som do violão do novo Orfeu, aparecem no epílogo como símbolo da renovação da vida na permanência da beleza do canto, a garotinha do início do filme de Diegues, que antes, sambando revigorava o morro, agora tem pressa. O nascimento do sol, no Orfeu negro, é movido pelo novo Orfeu menino, que se encanta e encanta os outros. Em Orfeu, o nascimento também tem a participação das crianças, são elas que pedem ao músico que "continue tocando", para que o sol não caia, mas o belo nascimento do sol (belíssimo, aliás), admirado também pelos vários animaizinhos, parece funcionar antes de tudo como um respiro (do mundo) frente a toda tortura posterior e não como resultado da atitude e desejo das crianças (embora este desejo exista e aflore ainda mais no pedido das crianças para que Orfeu continue a tocar). Diferentemente do Orfeu da Conceição, em que o sol nasce no início e volta a nascer no final do filme, em Orfeu, o feito do músico está apenas no início, quando recebe aplausos - pressupondo um fim, como todo espetáculo - , deslocado do cotidiano cruel do Morro da Carioca.

Nos dois filmes, Orfeu desfila na escola de samba homônima do morro em que mora. No primeiro, temos a "Unidos da Babilônia"; no segundo, a "Unidos do Morro da Carioca", que desfila no Sambódromo e na tela de televisão.

Aliás, a televisão e também o celular funcionam quase como personagens no filme, intervindo no destino ou atitude dos personagens. Antes de deter 
Eurídice, angustiada por ter presenciado a morte e o "julgamento pela lei do morro", seguido de morte, Orfeu pára por uns instantes para desligar o celular que toca. O cantor só se afasta do aparelho, para deixá-lo ao alcance de Eurídice e assim falar com ela no início da manhã, quando ele está no sambódromo. O celular chega a salvar sua vida. A arma apontada para ele é desativada por um triz, ou melhor, por um toque mais rápido do que o armado Super-Homem. Além disso, quem provoca a suspensão do assassinato é a imagem do músico vista por Lucinho, na televisão, e não as boas lembranças do traficante do tempo em que brincavam juntos (lembranças usadas por este como argumento, para tentar convencer o músico a cooperar com o tráfico de drogas no morro).

O fascínio de Carmem (tia de Eurídice) pela televisão, já expresso no seu relato sobre as camaradagens de Lucinho e sobre as mulheres que, tornando-se famosas, conseguiram sair do morro, volta quando ela, desfilando na avenida, chama a atenção dos repórteres, querendo ser entrevistada. A tentativa fracassa devido à impossibilidade de ouvi-la, mas seu desejo fica registrado pelo ritmo da imagem fílmica de Carmem, que a desloca do tempo do desfile para o tempo de sua fala. Embora descartada pelos repórteres, ela saboreia o seu pseudo-minuto de celebridade. Este momento, em que a personagem pensa estar aparecendo na tv, é o único do filme em que ela esboça um sorriso.

Além de "evitar" a morte de Orfeu, a televisão atua como personagem em outros momentos, interferindo na vida do músico. O policial exige que ele não se "intrometa" na próxima batida no morro, temendo que o músico atraia o noticiário da tv e o conseqüente registro da atuação abusiva da polícia no morro. Sagaz, o policial conhece a força persuasiva desse tipo de imagem e os cuidados que deve tomar, para não ser afastado do seu cargo. Por outro lado, o aparelho - veículo do que se toma como Verdade, seja a da grande festa carnavalesca, a do desempenho do novo compositor de escola de samba etc... - pode anunciar também "um tiro perdido" que atinge fatalmente o artista da vez, encobrindo o delito do representante da lei.

Esses recortes já apontam as escolhas principais e diferentes das duas adaptações de Orfeu da Conceição. Como as suas imagens do nascer do sol, as 
escolhas de Camus são difusas e panorâmicas, unindo as personagens do morro, as crianças, Orfeu e Eurídice à natureza. Já em Orfeu, o vários de close-ups destacam a diversidade dos personagens e tramas que perpassam o tema principal, enquanto as cenas panorâmicas, vez por outra, traz com elas a truculência, vinda quando a câmera se abre. Tanto a violência expressa pela ação policial como a do comando do tráfico, por exemplo - igualando instituição pública e contravenção, em prol dos interesses de poucos -, precipitam-se contra a possibilidade de unidade entre o nascimento do sol (vindo, nos dois filmes, com o canto de Orfeu) e os personagens do filme de Carlos Diegues.

O "Morro da Babilônia", de Orfeu negro, apesar de realmente existir na época um morro homônimo, remete-nos a outra cultura, indeterminando, de certa forma, o seu lugar. A alusão ao mito de Orfeu feita pelo funcionário do cartório e depois pelo próprio Orfeu e por Eurídice, assim como o acréscimo de Hermes, como mais um personagem, aproxima o morro, onde vive o novo Orfeu, do mundo mítico, em que os significados são expressos por metáforas, e onde o sentido é derivado do diálogo entre as imagens construídas. Mais do que um registro da "realidade brasileira", tal qual Carlos Diegues tenta realizar ${ }^{207}$, o filme de Camus é o registro de um potencial real existente e expresso pelo morro - incorporado pelo Orfeu cantor -, sob ameaça, como as belas construções da cidade e o carnaval, que começava a se institucionalizar.

As repetidas imagens do Cristo Redentor - que Orfeu faz questão de identificar para Eurídice - cartão postal do Rio de Janeiro e do Brasil, explicitam o lugar onde se dá a tragédia de Orfeu, assim como as várias vezes em que o "Morro da carioca" é identificado durante o filme: no sambódromo, quando anunciam a "Unidos do Morro da Carioca", na rádio local; na contagem das notas recebidas pelo desfile e na TV (durante a cobertura da festa carnavalesca e durante o noticiário policial).

\footnotetext{
207 As presenças de Joãozinho Trinta - reconhecido carnavalesco do Rio de Janeiro-, do cantor Caetano Veloso e do cantor Toni Garrido (este representando o próprio Orfeu), exemplificam a idéia da realidade forjando o caminho desse Orfeu metropolitano.
} 
Reconhecemos as imagens do morro de Orfeu negro, porque conhecemos aquelas paisagens, mas não há a intenção de precisar o lugar. O morro de Camus é idílico, lugar ideal, mas comum também, que se dispõe ao desejo. ${ }^{208}$

O novo Orfeu é cantor popular de sucesso, essa é a sua profissão. Seus sambas deram à escola o título de tricampeã do carnaval. Em seu quarto, o velho violão - herdado de seu pai, como na peça -, está acompanhado pelas fotos dos antigos compositores e cantores de samba do Rio de Janeiro, como Pixinguinha e Noel Rosa. Seu instrumento, agora, tem o som amplificado e transmitido para toda a favela. A expressão particular, o canto dirigido à amada, tocado em seu quarto, quando espera por seu novo encontro com Eurídice, transforma-se também em espetáculo (como o nascer do sol), transmitido pelos alto-falantes distribuídos pela favela. Suas canções são transcritas em laptop. Os animais não dividem mais a casa com o músico. Orfeu mora na parte mais alta do morro, mas agora, também na parte mais alta, mora seu antagonista, Lucinho, o chefe do tráfico de drogas, que, com Orfeu, divide o interesse e/ou amizade dos habitantes do morro. $O$ Inferno não é mais o sinônimo da cidade, ele sobe ao morro.

A morte, que na peça era representada pela Dama da Noite e no filme de Camus pelo homem fantasiado de caveira, sempre em busca de Eurídice, expande-se pelo morro, pelos corpos jogados no precipício, lateral à favela resultado do tráfico de drogas e da "lei do morro" -, pelas balas de todos os calibres, tanto de armas que sobem o morro quanto daquelas que estão nele. $A$ Paz, reclamada em canção por um menino, em Orfeu da Conceição, agora, no filme de Diegues, está no morro, mas como sigla usada pelo tráfico para demarcar o território sob seu "comando" ${ }^{209}$. No Morro da Carioca, o símbolo disso e do que,

\footnotetext{
208 Uma construção evidente nesse "mundo possível" é o trajeto de Eurídice e o de Orfeu, aproximando lugares bem distantes da cidade do Rio de Janeiro. A presença de Cartola e sua esposa, dona Zica, como personagens, na fila do cartório, para marcarem o casamento, não deixa de ser uma construção, semelhante ao trajeto admirado por Orfeu. [Os trajetos de Eurídice e de Orfeu são descritos por Ruy Castro; a informação sobre a presença de Cartola e dona Zica também é feita por ele, em Um filme é para sempre. São Paulo: Companhia das Letras, 2006.

${ }_{209}$ O menino Maykol entoa esta mesma canção ('Paz muita paz! Que falta nesse mundo ela me faz, rapaz"), como o menino da peça de Vinícius, mas, diferentemente desse, que junto aos amigos "não davam muita atenção" ao clima trágico perto deles, Maykol é abalado pela chegada de Orfeu trazendo Eurídice morta, abandonando o quadro que pintava, para ir ao encontro do amigo.
} 
de forma reducionista, podemos chamar de lado mau do morro, em contraponto ao lado bom, de Orfeu, é Lucinho.

Lucinho traz no próprio nome o índice do Inferno de Lúcifer, lugar para onde se dirige Orfeu à procura de Eurídice. O novo personagem, identificado à morte, participa de outros dramas que não estavam figurados nem na peça de Vinícius nem no filme de Camus: o linchamento, que segue a "lei do morro"; as invasões da polícia atirando para todos os lados; a partida da família cuja senhora levou um tiro de "bala perdida"; a quase prisão do menor recém-integrante do "movimento" das drogas no morro; os pedidos de dinheiro para compra de remédios e o percurso singular do menino Maykol, a todo tempo entre o mundo artístico de Orfeu, de seu ídolo, Michael Jackson, e de seus próprios desenhos, e o mundo de Lucinho, que lhe dá o "tênis manero" visto na televisão.

Os acréscimos, fidedignos a muito do que se tem notícia, pelos meios de comunicação, sobre as favelas (onde domina o tráfico de drogas e onde a polícia representa "a única coisa do governo que sobe o morro", como desabafa Orfeu) certamente derivam muito também da contribuição dos co-roteiristas do filme: o sociólogo Hermano Vianna e o escritor Paulo Lins, autor de Cidade de Deus, ficção baseada em sua vivência na favela homônima a seu livro.

Essa morte difusa, ameaça cotidiana aos moradores da favela, marca a distinção entre o cantor, que faz nascer o dia, mesmo que como espetáculo, e o traficante, que mata Eurídice.

O personagem de Maykol é resultado exemplar da oposição entre Orfeu e Lucinho, no morro, principalmente na cena em que o menino pede dinheiro ao músico para comprar o tênis visto na televisão, sugerindo sua outra alternativa para conseguir o que quer: "Se eu pedir pro Lucinho ele me dá!".

Na cena anterior a essa, o garoto surpreende Eurídice duas vezes: quando ela pensa ter sido ele o autor da perfuração de uma bala na parede e quando descobre suas pinturas, coloridas e que cobrem todo o muro, onde só se via a perfuração da bala. A abertura da câmara causa-nos a mesma surpresa, 
descobrimos, assim, a habilidade e dedicação do jovem apenas aparentemente alienado a tudo.

Como sua própria resposta quanto ao que faz na vida, que diz ao mesmo tempo que parece nada dizer, ${ }^{210}$ ele é e sabe que é Reginaldo, mas quer ser Maykol e faz o seu papel pintando o cabelo e colorindo sua roupa e corpo, burlando a vida que corre ao lado do tráfico de drogas. Finalmente, consegue o tênis "irado", dado por Lucinho, mas depois faz o quadro de Orfeu, na avenida. Quer ser dono de banco, sim, mas também, astronauta. Por tudo isso, os gritos do menino, no final, entregue à fatalidade de Orfeu morto, imploram a superação da morte do amigo e do destino, seu e dos que ainda sonham, ecoando a pergunta inconformada e a constatação de Eurídice depois de presenciar o assassinato no morro: "Até quando vai ser assim? Isso nunca vai mudar!".

É preciso assistir a Orfeu mais de uma vez, quando se quer compreender o porquê da força desta última cena, considerada até mesmo por quem não gostou do filme.

A série de tiros e tiros e as sirenes acionadas a todo o tempo - que legitimam a visão do diretor sobre o cotidiano das favelas como esta -, incorporam de tal forma a morte, que se torna difícil perceber vida nas personagens, às vezes próximas à caricatura, como a manicure, por exemplo. Como conseqüência, o filme passa, ironicamente, pelo inverossímil, errando justamente em relação ao ponto que queria corrigir: a denúncia dos problemas sociais vividos pela população pobre do país.

Desconsiderando isso, as personagens e seus dramas vão sendo percebidos entre o mundo sugerido por Orfeu e suas canções e o mundo em que se vive, do comando do tráfico de drogas e dos produtos modernos do mercado, cuja companhia passa ser morte ou a sensação de fracasso pessoal. As personagens que cruzam com seus dramas a tragédia de Orfeu e Eurídice, antes de serem definidas apenas como tipos, como apontaram alguns críticos, podem

210 “- Eu tô 100\% dentro do sentido de tudo, mas no momento eu estou parado pensando na vida, meditando, meditando". 
expressar, por outro lado, o estado urgente, e real, de quem é obrigado a sempre olhar para o que acontece fora de si mesmo: os tiros, o tênis "manero" imposto por repetição pelas diferentes mídias, a "primeira capa" na revista masculina, o celular, ser destaque na escola de samba; brechas para se sentir fora do morro. A história particular deixa de ter espaço, como se não existisse, como ocorreu nas avaliações de estatísticas dos recenseamentos de 1948 e 1950., comentados anteriormente.

Parece ser isso que explode na cena final, também da dor maior, da falta que pulsa à procura de consolo: desejo de vida, transformado em cadência, em música que dá vazão ao choro interno, impedindo a loucura. Exemplo da dor que o samba carrega desde sua origem. ${ }^{211}$

No filme de Carlos Diegues, somente o canto de Orfeu r passa pelo mundo midiático, produtor dos sonhos de consumo de personagens como Carmem, Maykol e Mira, sem perder sua função expressiva.

Também no filme de Carlos Diegues é uma criança que se destaca nas últimas cenas, mas diferentemente da obra de Camus, ela não traz de volta a paz, mesmo que espetacular, do início; não traz, tampouco, a sensação esperançosa, ideal, do filme do final da década de cinqüenta. Mas é justamente na seqüência final de Orfeu, que seu diretor consegue dar uma dimensão artística à questão social cruel vivida no país.

A música vinga, como nas outras duas obras, mas vem ainda mais carregada de agonia, transfigurada. Carlos Diegues retoma o mito original de Orfeu, que, despedaçado, continuava chamando Eurídice, mas, no filme da década de 90, não se consegue articular mais nenhuma palavra. Presas na garganta, elas só se expressam pela marcação do som agudo do apito angustiado, produzido pelo pai de Orfeu, que volta ao samba, depois de ter se afastado dele, respondendo aos gritos do garoto, sem fala e cheio de dor.

\footnotetext{
${ }^{211}$ Como explicita a canção Desde que o samba é samba, de Caetano Veloso: "A tristeza é senhora / Desde que o samba é samba é assim / A lágrima clara sobre a pele escura / A noite a chuva que cai lá fora / Solidão apavora / Tudo demorando em ser tão ruim / Mas alguma coisa acontece agora em mim / Cantando eu mando a tristeza embora // O samba ainda vai nascer / O samba ainda não chegou / O samba não vai morrer /Veja, o dia ainda não raiou / O samba é pai do prazer / O samba é filho da dor / O grande poder transformador".
} 


\section{4- Presenças de Orfeu}

Na peça de Vinícius de Moraes, "O morro é Orfeu"; no filme de Marcel Camus - assumindo o violão herdado -, o novo Orfeu vem de uma "velha história", que volta, em um outro tempo e lugar; em Orfeu, de Carlos Diegues, ele é "o Rei do Carnaval".

Os três percursos do mito cantor, seguindo a ordem cronológica das obras, relacionam-se a outros dois percursos: o dos morros, que praticamente, desde a sua origem, são identificados genericamente por favelas, e o do carnaval do Rio de Janeiro.

Ao lado dos diferentes caminhos, marcando o próprio canto de Orfeu, encontra-se Eurídice, novamente. Diferentemente do mito, os novos Orfeus parecem optar por ela frente à desmedida do mundo ao seu redor.

\section{Orfeu da Conceição}

Orfeu da Conceição e o morro são um só. Ele pertence ao lugar onde vive e deriva dele, como seu nome sugere, determinando essa unidade, mesmo antes de Eurídice chegar. Assim como o "morro é Orfeu", Orfeu é Eurídice. Sua opção por ela revela-se também como opção pela vida no morro; ele é o "músico do morro". Com ela, esse vínculo alcança um tom ainda maior, que leva ao sublime, mas pela marca da dor. Encontrando-a, não consegue mais viver sem ela. A unidade completa-se com esta opção, metáfora da escolha pela poesia, que implica vida e morte e a capacidade particular de expressar isso; capacidade daquele que, mesmo optando pela vida, ou justamente por isso, desceu aos infernos à procura de sua amada.

Submetido à paixão, Orfeu mergulha nela e de seu canto emerge a vida e tudo o que vem dela, inclusive a morte. Ele é o "músico total", cujo canto vem 
"gratuitamente" de seu violão, a partir do que o músico vivencia, como extensão do que sente, filtro dos males do morro, vindos da cidade.

Ao contrário do que é divulgado pelas autoridades e por grande parte da imprensa da cidade do Rio de Janeiro, da mesma época, o inferno, em Orfeu da Conceição, não é o morro, mas sim a cidade. Nela está o carnaval do "Clube dos maiorais", cuja alegria é a ordem do dia. Não a sensação própria que se exterioriza, mas a alegria de tempo marcado e sob o comando do Rei. A cidade, que recebe as canções vindas do morro, é a mesma, que expulsa os pobres em nome de progressos, que ficam na cidade.

Mesmo emudecendo, o canto do músico prolonga o carnaval pela voz das crianças, que batucam em seus caixotes de engraxate e escolhem suas canções, animados por elas.

O Orfeu de Vinícius de Moraes é a expressão do seu "sentimento do mundo". Os problemas da cidade, invadindo o morro depois de sua voz emudecer, são os sinais mais evidentes do tormento latente do artista e da sua consciência dos paradoxos do mundo, para o bem e para o mal. O Orfeu de Vinícius parece ser o fruto de sua própria descoberta: no mito, o canto sobrevive à morte da amada e do próprio Orfeu; no morro, a criação desabrocha onde não se supunha que pudesse acontecer, sugerindo um outro tom, inesperado. A experiência do poeta no morro associada ao mito de Orfeu relaciona-se à atitude de todos os poetas que, passíveis ao que está ao seu redor, procuram, pelo possível e impossível, transportar-nos a esse tom maior do mundo, com seu canto justo. "Subamos", convida-nos o poeta. 


\section{Orfeu negro}

O novo dono do violão de Orfeu traz com ele "uma velha história". O bonde que se identifica à parte histórica da cidade, admirada pelo olhar do músico, leva-o ao encontro do amor de Eurídice, no morro.

O personagem de Camus traz o seu canto para a cidade, como o Orfeu da Conceição, e traz, também, o sol para ela. Os habitantes do morro agora são a Unidos da Babilônia; a roda de samba e o "samba no pé" dos adultos e das crianças transformam-se em desfile de carnaval com seus passistas e suas fantasias, na avenida, com os aplausos da população em coro, acompanhando a Escola.

Orfeu é reconhecido enquanto sambista, é aplaudido e homenageado, no mesmo momento em que Eurídice começa a ser perseguida. Ingenuamente, aquele que traz o sol para a cidade, perde sua amada.

A luz da cidade, que não chega ao morro e que agora ilumina os passistas da Unidos da Babilônia, ironicamente, mata Eurídice, afastando-a definitivamente do músico, logo desprezado pela mesma cidade, representada por suas autoridades e burocracia; a mesma cidade que durante um momento reconhece suas canções e seus passos de sambista, em outro, mas não percebe a sua tragédia. Novamente, como na peça de Vinícius, a cidade opõe-se ao morro, mesmo quando parece lhe dar as boas vindas.

A canção vem do morro para a cidade, que não lhe leva nenhum bem.

Camus convida-nos a seguir Orfeu em direção ao morro, talvez seduzido, como parece, pelo que vê ali e talvez temeroso da insensibilidade da cidade, traduzida em pressa, burocracia, e em conflito também com a beleza presente nela mesma. O olhar de Orfeu, antes de sair em direção ao morro, admira as belas construções, que parecem ameaçadas pelos enormes prédios, arranhando os céus e sem lugar para todos, identificando-se talvez ao olhar do diretor do filme. Como narciso, Orfeu admira a sua própria imagem, de antiga forma. O olhar 
de Camus, em seqüência, admira este outro lugar para onde o bonde nos leva, "pertinho do céu", como dizia outro cantor $^{212}$, aonde os ganhos da modernidade, infelizmente, não chegaram, mas de onde, inesperadamente, o canto e a beleza singulares despontam num movimento só, gerando um "apesar de" surpreendente, acima dos males do morro derivados dos males da cidade.

O enfoque de Vinícius de Moraes prende-se à vitalidade do canto poético identificado à voz resistente do morro em oposição ao desprezo da cidade. Camus confirma essa vitalidade do canto e do morro e alerta sobre o perigo da interferência negativa da cidade nessa cultura, atraindo Orfeu para junto dela, mas matando Eurídice.

A Eurídice do filme de Camus vem do interior, harmonizando e ressaltando junto a Orfeu a proximidade ideal entre o homem e a natureza, ou, por extensão, a necessidade do homem de conviver com o belo. Ela traz a referência à "idade de ouro", à qual os mitos costumam nos reportar. Este outro Orfeu também opta por ela, mas, por ingenuidade dele, as conquistas da modernidade matam Eurídice, sua aspiração sublime, sugerindo o perigo dessas luzes da cidade que iluminam os passistas e as suas fantasias.

A morte de Eurídice pode significar aquele desbordamento perverso da cidade, novamente calando o canto, que opta pela poesia, por causa ou a despeito disso.

A institucionalização do carnaval, as homenagens a Orfeu e à Escola Unidos da Babilônia, a "aceitação" do morro são os indícios dos perigos pelos quais o tom idílico, exaltado por Camus e sugerido por Vinícius, passará. $\mathrm{Na}$ seqüência, o filme de Carlos Diegues pode ser tomado como o resultado desse presságio expresso por Orfeu negro.

${ }^{212}$ A expressão pertence à canção Ave Maria no morro [1942], de Herivelto Martins. 
Orfeu, o "Rei do Carnaval"

Orfeu, como na peça, é Orfeu da Conceição; mas Conceição agora é a sua mãe, que, por sua vez, não é lavadeira no morro, mas passista da escola de samba, comandada por seu filho, o "Rei do Carnaval", integrado à cultura de massas e ao mercado de consumo. $O$ morro não é mais Orfeu, assim como o carnaval, que já ganhava a avenida, também não é mais o mesmo. A festa dos adultos e crianças tem agora patrocinadores e projeção. É o grande negócio do morro e da cidade, dentro e fora do lugar que lhe foi destinado: o Sambódromo.

A morte não se personifica mais, nem como Dama Negra, nem como fantasia de carnaval; ela está em todas as partes, tanto no morro quanto na cidade. Eurídice, como no filme de Camus, vem de fora do morro e também do interior do país, mas não foge de uma fantasia, e sim da morte real que, na guerra do garimpo, matou seu pai "com um tiro na boca". Ela já carrega em si uma tragédia e termina sendo morta pelos males sociais quatro décadas piores do que os do filme de Camus, que chegam ao ponto de o próprio Orfeu matar, vingandose.

No filme de Diegues, a canção aparentemente não vinga (embora em meio aos tiros do filme, um outro canto, ao violão, que também remete ao mundo real expresso por Carlos Diegues, continue a reafirmar o valor Eurídice); as palavras deixam de existir, como o casal apaixonado, restando apenas o som do apito pedindo uma nova canção. A aspiração sublime parece transformar-se em inspiração possível.

Apesar de morrerem, como no mito, os três Orfeus preservam o domínio sobre si mesmos. Mesmo o Orfeu do Carnaval, imerso no mercado de cultura de massas, transformado em "bem de consumo" (sinônimo do que, a princípio, não se produz para durar), promove o desejo de que o carnaval saia do Sambódromo e vá para o seu verdadeiro lugar, totalmente institucional, no melhor dos sentidos: as ruas, sem cobrança de ingresso. 


\section{5- Dialogando com outras críticas e depoimentos sobre Orfeu da Conceição, Orfeu negro e Orfeu}

A estréia de Orfeu da Conceição teve a casa lotada. A cortina subiu, "sob os aplausos da platéia, ao final de cada ato, (quatro vezes no primeiro, cinco no segundo e oito no terceiro)". Rapidamente, esgotaram-se os mil exemplares do programa desenhado por Carlos Scliar. Depois das seis récitas apresentadas no Municipal, a peça voltou, desta vez no Teatro República e só não estreou em São Paulo pela falta de um teatro em que pudesse cumprir um temporada normal.

Quanto às críticas publicadas na época, na imprensa

só duas vozes destoaram do entusiasmo geral. Na Revista do Globo, Gasparino da Mata criticou a "falta de entrosamento" entre a música e a poesia, e no jornal Correio da Manhã, o jovem crítico Cláudio Murilo lamentou que as composições de Jobim não possuíssem "as características do samba do morro: maleabilidade, dolência e espírito de negro". Joaquim Cardoso achou justamente o oposto. Nelas viu "uma extensão do samba numa obra de mais fôlego, de maior penetração no tempo, de mais apelo ao fundo emocional e sensual de nosso povo". Mesmo apontando alguns "erros de mise-en-scene", o respeitado crítico da Tribuna da Imprensa, Mário Cabral, considerou a peça uma inédita e bem sucedida folk-ópera brasileira, comparável a Porgy and Bess, de George Gershiwin. "Seu primeiro ato é uma obra-prima", sentenciou Cabral.

"Já nasceu clássica", proclamou Guilherme Figueiredo. Fabulosa e absolutamente inédita no Brasil", escreveu o colunista de O Globo, Elsie Lessa. O Diário Carioca publicou duas exaltações ao espetáculo: uma assinada pelo maestro Radamés Gnatalli e outra pelo editor Ênio Silveira. Entre os intelectuais, apenas o poeta Manuel Bandeira e a jornalista Adalgisa Nery the fizeram restrições. Bandeira saiu da representação no Municipal convencido de que a obra de Vinícius "ficaria muito melhor se realizada em cinema". Adalgisa apreciou a poesia de Vinícius e os cenários de Niemeyer, mas não gostou da concepção da peça. Jorge Amado adorou: "É um dos pontos mais altos da obra poética de Vinícius, e a música, toda ela, é excelente". Aníbal Machado também se rendeu à novidade: "Desde Aruanda, de Joaquim Ribeiro, não se repetia em nosso teatro negro experiência tão bela e audaciosa". ${ }^{213}$ [grifo meu]

${ }^{213}$ AUGUSTO, Sérgio Augusto. “Orpheus, Orphée, Orfeu”. In : Moraes, Vinícius. Op. cit., p. 41. 
Vinícius conheceu o futuro produtor de Orfeu negro, Sacha Gordine, por intermédio de uma amiga em comum, Mary Meerson, em um jantar no Le Doyen, dos Champs-Elysée, onde coincidentemente a Panair do Brasil dava um festa com artistas brasileiros. Gordine procurava um roteiro que tivesse um assunto brasileiro, mas ao mesmo tempo um interesse internacional. Em outro encontro, o poeta falou sobre o Orfeu negro e, alguns dias depois, conforme o produtor the havia pedido, transpôs o Orfeu da Conceição (sua peça engavetada, pela inviabilidade de ser produzida no Brasil) em termos cinematográficos simples. A idéia foi prontamente aprovada.

Se, por um lado, toda a movimentação provocada pelo anúncio da filmagem de Orfeu no Brasil funcionou como alavanca para a encenação da peça, antes impossível, e para que a música de Vinícius e Tom Jobim tivesse o reconhecimento merecido fora do país, por outro, a realização do filme causou uma série de conflitos, desde os relacionados ao roteiro até os que envolviam os direitos autorais sobre as canções.

O trecho da carta de Vinícius para Tom Jobim sugere a dimensão dos conflitos, mas, além disso, também expõe o lado positivo do lançamento de Orfeu negro, o reconhecimento internacional de suas canções:

[...] Tocam a gente por aí tudo, Tonzinho. Eu acho que não vai haver outro jeito senão tomar advogado contra a SBACEM [Sociedade Brasileira de Autores], porque, francamente dá raiva. Estamos em todos os jukeboxes, desses de quiosque de café de rua. "Chega de saudade", "Desafinado", "Brigas, nunca mais". Só eu gastei 200 liras para ouvir, o Scliar está do meu lado que não me deixa mentir. O Mário Perrone, um cantor amigo meu, [...] quando eu disse que só tinha recebido uns quinhentos ou seiscentos contos pelas músicas de Orfeu, levantou-se tão agitado que pensei que ele estivesse tendo um troço: "Se você não processar, EU PROCESSO".[...] Basta dizer que nessa noite - Nelita ouviu - tocaram, nossos, uns cinco ou seis números. Tudo igualzinho aos Cariocas, sem tirar nem pôr, só um pouquinho mais ajustado. $\$ 40$ danço samba, $A$ felicidade, Chega de Saudade, Brigas nunca mais [...] O [Sérgio] Amidei fez uma gestão, a meu pedido, junto à Sociedade daqui, tendo como resposta o seguinte: é tudo pago à Sociedade...de lá. E é MESMO. O negócio aqui é batata. O furto é todo feito aí. Isso aqui na Itália. E os outros países? 
Mostre esta carta (este trecho) ao [Umberto] Marconi. É uma vergonha! ${ }^{214}$

Apesar de todos os prêmios ganhos no exterior, o filme de Marcel Camus sofreu várias críticas no Brasil, tanto na época em que foi lançado, como no período de estréia de Orfeu, de Carlos Diegues.

Manuel Bandeira, que tinha achado a peça "mal realizada e mal interpretada" e que "ficaria muito melhor se fosse realizada em cinema", decepcionou-se ao ver o filme:

O filme é para funcionar fora do Brasil, para os estrangeiros que não conhecem o Brasil, ou que apenas o conhecem de passagem e superficialmente. Há nele um parti pris de exotismo, que, a par de outros elementos bem acusadamente franceses, o tornam, para nós, ao contrário das intenções do diretor, bastante insípido [...]

Mas, por outro lado, o poeta destaca:

a presença autêntica de tanto negrinho bom do Brasil (especialmente Orfeu e os dois menininhos estão magníficos).

e observa que:

O filme vale como documentário. Documentário da paisagem carioca, do carnaval carioca, da vida nas favelas dos nossos morros [...] documentário da macumba (esse o ponto mais alto a esse aspecto). Excesso de carnaval, excesso de dança, dentro do qual quase se perde a história de Orfeu, reduzida a um fio tênue, que se não se parte, é porque a técnica de Camus o conduz com magistral habilidade. ${ }^{215}$

Jean-Luc Godard faz em sua crítica ao Orfeu negro, "Le Brésil vu de Billancourt", no Cahiers du cinema ${ }^{216}$ - de pouco mais de uma página e onde

\footnotetext{
${ }^{214}$ Carta de Vinícius a Tom Jobim. Roma, 8 de novembro de 63 In: Moraes, Vinícius. Cancioneiro Vinícius de Moraes: Orfeu: songbook / músicas de Antônio Carlos Jobim e Viníicius de Moraes. Rio de Janeiro: Jobim music, 2003, p.71.

215 Bandeira, Manuel. "Orfeu do Carnaval". Andorinha, Andorinha. Rio de Janeiro: José Olympio,1966, p.140.

${ }^{216}$ Godard, Jean-Luc. Paris, 1960, p. 59-60.
} 
evoca três vezes o Orphée, de Jean Cocteau, (“avez-vous revu Orphée?'[...] ("avez-vous revu le film de Jean Cocteau?) -, apenas um elogio a Marcel Camus: "La gentillesse et la sincérité de Marcel Camus ne sont pas en cause". Gentileza e sinceridade que para ele não são suficientes para fazer um bom filme. Godard reclama, principalmente, de não ver o Rio de Janeiro que ele conhecia; cobrava do diretor cenas mais poéticas como seria a de um cobrador de lotação (função mais apropriada para um Orfeu brasileiro) numa das lotações que ligavam o Maracanã a Copacabana, segurando o dinheiro dobrado entre os dedos, para assim facilitar a entrega do troco aos passageiros.

Como observa o crítico Tunico Amâncio

Os detalhes são saborosos, porque ele [Godard] reclama da ausência do aeroporto Santos Dumont (onde Eurídice poderia ter aterrissado) ou da ausência de um trocador de lotação [...]. Ou também de um descarrilhamento de trem, assunto no qual a rede ferroviária brasileira seria especialista. Ele termina dizendo que é um filme de aventureiros sem aventura, um filme de poeta sem poesia. E que ser gentil e sincero não é garantia de se fazer um bom filme. Godard reclama realismo, Godard reclama verossimilhança, Godard reclama paixão cinematográfica"217

Caetano Veloso comenta o seu riso e o de toda a platéia envergonhados das "descaradas inautencidades que aquele cineasta francês se permitiu para criar um produto de exotismo fascinante"218 [grifo meu]. Não gostaram, principalmente, do que tomaram como visão exótica do Brasil; não viam no filme o que esperavam, enfim, não se reconheciam e não reconheciam os brasileiros ali. Por outro lado, o cantor e compositor de canções, como já vimos, também reconheceu o filme de Marcel Camus como a primeira grande expressão cultural do Brasil no exterior, depois do futebol e do Carnaval.

Para Vinícius de Moraes, o filme de Camus, como ele descreve:

${ }_{217}^{217}$ Amâncio, Tunico. O Brasil dos gringos: imagens do cinema. Niterói: Intertexto, 2000, p.70-1.
${ }^{218}$ Veloso, Caetano. Verdade Tropical. São Paulo: Companhia das Letras. 1997, p. 252. 
Foi uma das maiores decepções que eu já tive na minha vida. Eu não tinha visto o copião e estava em Montevidéo quando recebi a notícia de que o filme havia recebido a Palma de Ouro em Cannes. Aí eu pulei e vibrei, torci à beça, achei que eles tinham acertado na mosca. Depois, quando cheguei aqui, o [presidente] Juscelino [Kubitschek] me convidou para a primeira exibição privada, no palácio, junto com sua família, e dois ou três sujeitos da produção. Eu tive um choque tão grande durante a projeção que me esgueirei e fui embora. Senti que não poderia enfrentar aqueles franceses quando as luzes acendessem. Eu era capaz de partir pra porrada com eles. ${ }^{219}$ [grifo meu]

Mesmo concordando com seu parceiro, Antonio Carlos Jobim reconhece a beleza do filme:

O nome do Orfeu aqui é enorme e imortal, é estátua de bronze inoxidável, e o filme não podia ser mais ao gosto americano do que é. É uma fantasia (fantêijia), como dizem eles aqui. Noutro dia passou o Black Orfeus, na TV por aqui. Perdi porque saí. Mas eu vi o Orfeu três vezes na TV e é todo dublado em inglês da Jamaica. O nome do Orfeu é sagrado e quando, em conversa, eu disse que gostava mais da peça original do que do filme, porque este me parecia muito irreal e meio Brasil Exotique, a turma [...]disse: "It's not supposed to be real, it doesn't intend to be real etc.". Claro que uma certa irrealidade existe em qualquer obra de arte (e eu não sou contra ela), mas é uma irrealidade que serve para mostrar a realidade, e não as idéias do sr. Camus, que, para mim, são às vezes, de gosto duvidoso. ([...]Vina, juro que nunca escrevi tão mal [...]mas "desculpa". É só saudade de você e a necessidade de comunicação, nem esta é para falar de coisas que você sabe melhor do que eu, e o filme é bonito, principalmente no cinema, não na TV, em cores e sem dublagem. Mas, eu, pessoalmente (I, personally), prefiro a Realidade Real, a Realidade Irreal ou a Irrealidade Real. O Camus parece que prefere a Irrealidade Irreal. Mas que faz sucesso aqui, faz...

[Carta de Tom Jobim para Vinícius de Moraes. Los Angeles, 10 de dez. de 1966] $]^{220}$

Logo em sua estréia, em 1999, Orfeu, de Carlos Diegues logicamente provocou comparações, mas não com a peça de Vinícius. A crítica - que não se limitou àquelas publicadas em jornais, estendendo-se em ensaios de antropólogos, sociólogos etc. - voltou sua atenção, quase que exclusivamente, para os dois filmes, praticamente esquecendo o texto que Ihes deu origem.

${ }^{219}$ Morais, Vinícius. Cancioneiro Vinícius de Moraes. Op. cit., p. 42.

${ }^{220}$ Idem. 
As análises desenvolvidas aqui buscaram conhecer esse diálogo entre os filmes e a peça de Vinícius, verificar o significado que o conjunto formado por eles (as diferentes presenças de Orfeu) expressa.

Contrapostos à peça, o tom idílico de Orfeu negro e a busca pela expressão dos problemas sociais do filme de Diegues, comumente observados, talvez nos levem a compreender melhor tanto as ressalvas ao Orfeu de Camus - mesmo daqueles que não gostaram do filme, sobretudo, pelo caráter exótico que viam nele -, como também o fato de o filme de Diegues, que vinha para fazer justiça à peça, aparentemente não ter tido este reconhecimento.

Penso que existe o que vou chamar de uma qualidade, semelhante entre a peça de Vinícius e o filme de Camus, que talvez derive da quase contemporaneidade das duas encenações, mas também da opção, comum ao poeta/dramaturgo e ao diretor, de ter apenas atores negros - fato praticamente inédito no teatro e inédito no cinema realizados no Brasil até aquele momento, "o que pode ser considerado uma revolução dos padrões de relações raciais da época" 221.

A vitória do canto frente aos males do morro une o Orfeu da Conceição ao Orfeu negro, relacionando-os à vitalidade dos mitos na forma do cantor identificado ao morro. O otimismo percebido nessas expressões mescla-se a um clima de expectativas positivas do final da década de 50 , difusas depois em nova capital do Brasil, na imagem-síntese promovida pelo presidente Juscelino Kubitschek - os "cinco anos em um" - , por um lado, e na vitória da copa do mundo de futebol e no sucesso internacional da Bossa Nova, por outro.

Passados quarenta anos, o Orfeu, de Diegues acompanha um outro momento. Em 1997, dois anos antes da estréia do filme, o Brasil "tornou-se a oitava economia do mundo, permanecendo campeão das desigualdades sociais" ${ }^{\text {222 }}$. Nesse período, um outro aspecto é acrescido à representação das favelas. Se antes eram diretamente relacionadas à pobreza e marginalidade depois do massacre da Candelária e de Vigário Geral, principalmente, passam a

\footnotetext{
${ }^{221}$ Santos, Myrian Sepúlveda dos. "Orfeu negro: entre fantasia e realidade". Op. cit., p.33. A observação de Myrian relaciona-se apenas ao filme Orfeu negro.

${ }^{222}$ Valladares, Licia. A invenção da favela. Op. cit., p. 119.
} 
ser identificadas à violência urbana, implicando ainda a corrupção da polícia, o tráfico de drogas etc. ${ }^{223}$. Enfim, um dos aspectos de Orfeu negro que mais desagradara Carlos Diegues - a falta de "todas as circunstâncias familiares e sociais de Orfeu [da Conceição]"224 -, toma o lugar de tema central dessa segunda adaptação.

Em seu ensaio, "Orfeu negro: entre fantasia e realidade", a socióloga Myrian Sepúlveda dos Santos ${ }^{225}$, menciona a crítica de Caetano Veloso, quanto aos brasileiros não se reconhecerem no filme de Camus, observando que o cantor coloca em questão "a universalidade de sentido presente em uma obra cinematográfica" e o perigo que a consagração de padrões não prestigiados pelos artistas e pelo público brasileiro produz na construção de uma identidade nacional. Mas mesmo legitimando essa preocupação quanto a Orfeu negro, Myrian observa também no filme de Carlos Diegues o distanciamento da realidade. Para a socióloga, por exemplo, as "imagens de violência, pobreza e conflito urbano, mais do que um retrato fiel do que seja o Brasil, constroem um estereótipo de um país de Terceiro Mundo assolado por seus problemas sociais". ${ }^{226}$ [grifo meu].

Em seu contraponto, ela observa que:

nem o primeiro filme é apenas uma fantasia artística, nem o segundo, uma descrição fiel da realidade. No filme de Camus, a parábola da eternidade da arte, mais do que uma montagem bem construída, aparece como farsa aos olhos dos brasileiros. Mas o filme traz elementos poderosos, capazes de colocar em questão a sobrevivência da arte, da sensualidade e mesmo do romance em meio à miséria. Por outro lado, as imagens que aparecem no filme dirigido por Cacá Diegues sem dúvida caracterizam de forma mais correta os problemas sociais e culturais que envolvem os protagonistas. No entanto, acabam por oferecer um estereótipo de país de Terceiro Mundo e enfraquecer a trama entre arte e vida, que é bem narrada no primeiro filme. ${ }^{227}$ [grifos meus]

\footnotetext{
${ }^{223}$ Idem, p. 142.

${ }^{224}$ Entrevista concedida à Maria Lúcia Rangel. In: Bravo! (Rio de Janeiro, maio, 1992, ano 1, n.8, p.93).

225 "Orfeu negro: entre fantasia e realidade", in: Cadernos de Antropologia e Imagem. (Rio de Janeiro, Universidade do Rio de Janeiro, Núcleo de Antropologia e Imagem, n.11, p.36).

${ }_{226}$ Idem, p.37.

227 Idem, p. 45
} 
Ainda segundo Myrian, a aparência ingênua do filme de Camus traz uma "visão emancipadora do carnaval que se encontra completamente ausente no segundo filme", incluindo "um elemento central para a representação não só do carnaval carioca, mas da própria vida cotidiana do Rio de Janeiro". Na história do Orfeu de Camus o Carnaval "permeia todas as interações sociais apresentadas", ao passo que no filme de Diegues isso não acontece, a festa é "apenas um componente a mais para ilustrar a vida na cidade. Para Myrian o Carnaval apresentado por Diegues

não está longe dos nefastos resultados da indústria cultural denunciada por autores da Escola de Frankfurt (Adorno e Horkheimer, 1979). Há uma descrição dos aspectos econômicos e políticos que envolvem o carnaval carioca. Embora o carnaval do Rio de Janeiro já tenha surgido associado a interesses da indústria cultural, aspecto que não está presente no filme de Camus, diversas práticas de irreverência que observamos durante o Carnaval fazem parte do cotidiano do carioca, aspecto minimizado na segunda produção.

Os dois filmes trariam uma representação de forma unidimensional, pois "os fenômenos sociais são não apenas mais complexos que as narrativas produzidas, como também ambivalentes diversos e sem definições rígidas".

Concluindo o seu texto, a autora relaciona as suas análises sobre os dois filmes ao que Slavo Zizek aponta sobre duas versões cinematográficas da peça Children's Hour ${ }^{228}$. Apesar de a primeira versão ser considerada "mais ingênua e com menos dados da realidade" ela traria consigo "elementos que descortinam aspectos inconscientes que dizem mais sobre a realidade do que a versão 'politicamente correta'”. [grifo meu]

Em texto publicado no New York Times ${ }^{229}$, alguns dias antes da estréia do filme de Carlos Diegues, em uma de suas menções a Orfeu negro, Caetano Veloso expressa um tom diferente do registrado em seu livro que não só vem ao

\footnotetext{
${ }^{228}$ Apud. Santos, Myrian S. Santos. Op. cit. : Zizek, Slavo. "Da capo senza fine". In: Butler, Judith; Laclau, Ernesto \& Zisek, Slavoj. Contingency, Hegelony, Universality: Contemporaty Dialogues on the Left. Londres : Verso, 2000.

229 "Orfeu, ascensão da Caricatura", New York Times, 20.8.2000.
} 
encontro do que expõe Myrian Sepúlveda acerca do filme de Camus, como identifica a proximidade entre o filme de diretor francês e a peça de Vinícius:

Assistindo Orfeu negro novamente, eu fui persuadido pelo quão certo Vinícius de Moraes estava em conceber sua peça. Na verdade, ele revelou o Brasil como um país órfico, um país que expressa docemente aspectos trágicos de sua alma através da música. Quase inconscientemente, o filme de Camus, com a sua irrealidade e ingenuidade, conduz-se para conectar essa verdade inconsciente. O que me chocou, inicialmente, como marcante naquele filme - as atrizes Lourdes de Oliveira e Lea Garcia, para não mencionar as canções, as cores, insultuosamente extravagantes (tão diferentes das cores reais do Rio) e o voodoo geral para a ambientação turística - parecia para mim, agora, dar ao filme a qualidade como que de sonho da religião popular iconográfica, e isso me tocou.

Registrado este aspecto, Caetano discute depois as diferentes reações que os filmes produziram, principalmente no exterior. Ele critica as impropriedades do texto publicado no jornal francês Liberation e no "longo artigo" do historiador e brasilianista Kenneth Maxwell, publicado na Folha de São Paulo sobre o filme de Diegues.

A inclusão do rap na ambientação da favela, que é marca da proximidade entre o filme e a realidade, verificada também por Myrian Sepúlveda, é entendida pelo primeiro crítico como um recurso cinematográfico para a passagem entre as cenas e não como um registro documental.

O historiador, brasilianista manifesta sua perplexidade diante da cena na qual "um homem branco de classe média é executado por um grupo de traficantes de drogas predominantemente composto por negros"; decepciona-se ao ver Orfeu usando trancinhas no cabelo e é "cético em relação ao gorro usado por um traficante no filme [...], mais apropriado para o frio de Chicago do que para o clima quente do Rio". Três enganos: o homem executado era habitante da favela; o uso das trancinhas do cabelo são "quase tão comuns no Brasil como na Jamaica e, 
finalmente "todo mundo que mora no Rio sabe que é raro encontrar um traficante de drogas que não use gorro". 230

Caetano Veloso prossegue seu texto, de maneira pertinente, considerando, por opção, não a qualidade artística dos das obras, mas as diferentes reações provocadas pelos dois filmes que promovem a discussão sobre a democracia racial e identidade do Brasil.

A atenção à qualidade artística das três obras observadas aqui não provará se há ou não uma democracia racial no Brasil, nem se a forma com que os brasileiros lidaram ou lidam com sua miscigenação e convívio entre raças diferentes é melhor ou pior do que o que acontece no exterior, sobretudo nos Estados Unidos, nem se a idéia da positividade de nossa miscigenação, destacada originalmente, sobretudo, por Gilberto Freire, foi melhor ou pior para qualidade de vida dos negros e descendentes de negros neste país, mas ela vem como a expressão de uma confiança que ainda continua na forma artística como meio de resgate desta "humanidade básica", que todos devemos ter e usar, a qual Caetano Veloso chama atenção em seu texto.

Tanto a peça de Vinícius quanto o filme de Camus representam a favela e seus habitantes de uma maneira positiva, reagindo contra a imagem comum divulgada pelos meios de comunicação e mesmo pelos órgãos institucionais, sobretudo quanto à marginalidade, só contestada muito tempo depois por avaliações mais isentas de preconceito racial. Mesmo identificado como exótico por brasileiros, Orfeu negro é geralmente bastante aceito fora do país, onde acreditam ou se satisfazem com o que vêem representado, ainda nos dias de hoje; e aqui relembro a composição do filme cujo elenco é composto basicamente por negros. Não penso que confirmem uma democracia racial, pois o conflito entre o morro e a cidade existe nas duas obras, mas creio que, relacionado também a isso, registram o poder da qualidade do canto no meio desse conflito e a reverência a isso.

${ }^{230}$ Veloso, Caetano. Idem. 
O filme de Diegues, mesmo representando a favela da maneira como vimos, não deixa de comungar dessa mesma crença do valor do canto. A imagem de Orfeu e Eurídice (que no filme é índia, ou branca), acompanhada pelos créditos do filme, juntos novamente, parecem legitimadas justamente pela potência da música da escola de samba entrando na avenida.

A cena traz com ela o respiro como aquele provocado pelo nascimento do sol, no início do filme, numa demonstração de confiança no valor do canto como um meio de superação dos conflitos. A cena lembra, inclusive, a imagem grega recuperada, no filme de Camus, depois que o canto de Orfeu volta com as crianças. A incorporação do rap ${ }^{231}$ ao samba enredo é preciso registrar, além de ser um dado documental é também o registro desse poder de expressão do canto, que ao seu modo ajusta-se, como o próprio filme de Carlos Diegues, à época em que vivemos.

Nesse sentido, é interessante a observação do crítico A.O. Scott sobre o filme de Diegues. Ele credita justamente às canções, as "nuances emocionais que faltam" no filme. Para ele,

a melhor música brasileira representada tanto pelos sambas carnavalescos quanto pelas canções delicadas da Bossa Nova na trilha sonora - de alguma forma funde o sentimento puro com a claridade intelectual, uma fusão que o filme aspira, mas que quase nunca alcança. [...] No final da música, a cidade e o ardor do compromisso de Diegues com sua História, com todas as suas contradições e confusões, eleva Orfeu acima de seus defeitos. O filme não é bem sucedido por colocar a prumo a profundidade da vida brasileira, nem por se elevar às alturas da alegoria, mas ele encontra uma vasta controvérsia entre documentário e mito - um lugar que apesar de tudo pode ser o Rio verdadeiro. ${ }^{232}$ [grifo meu]

A observação final do crítico assemelha-se tanto à retomada de Zisek, no texto de Myrian, como à definição de Caetano Veloso, quando aproxima Orfeu negro e Orfeu da Conceição. Talvez, também de maneira inconsciente, o filme de

\footnotetext{
231 Sobre a qualidade artística do rap cf. "Ouvindo Racinais MC'S", in: Teresa: revista de Literatura Brasileira. São Paulo: Editora 34/ Universidade de São Paulo, 2003, n. 4/5, p. 167-80.

232 "Rebord in a less romantic Rio, Orpheus seasons samba with rap", in: New York Times, New York, 25. 8. 2000.
} 
Diegues expresse ${ }^{233}$ algo que vai além das informações que nos chegam por diferentes meios de comunicação.

No final de seu texto, Caetano Velos faz menção à outra crítica positiva a Orfeu, de Diegues, feita por Robert Stam que, por outro lado, pode ser estendida tanto a Orfeu da Conceição quanto a Orfeu negro:

As favelas, para Diegues, são lugares de uma criatividade e injustiça. Para os produtores do filme e platéia, é difícil igualar injustiça e criatividade. O Brasil, como um lugar onde ambas coexistem, tenta provar que os esforços valem a pena.

${ }^{233}$ Myrian Sepúlveda dos Santos também observa que mesmo apresentando "visões unilaterais de fenômenos sociais" e expressando "muitos mitos presentes nas diferentes épocas em que foram produzidos", os dois filmes "ainda assim, são capazes de transcender os limites das análises associadas a cada período histórico”. Op. cit., p. 45. 
6- Orfeu é Vinícius (“o branco mais preto do Brasil”)

A unidade entre Orfeu e o morro estende-se à unidade entre Orfeu da Conceição e a poética de Vinícius de Moraes.

A associação entre Cristo e Orfeu, tratada pelo músico com indiferença; o posicionamento particular frente aos temores de Eurídice quanto a pecado e perdão; o equilíbrio órfico, entre as forças "apolíneas" e "dionisíacas" (vindo pelas relações entre as linguagens culta e coloquial, entre o soneto, tragédia clássica, canção popular, cultura grega e a cultura do morro) e, sobretudo, a criação do novo canto lírico são alguns traços semelhantes entre a peça e o percurso poético deste outro Orfeu.

Esses espelhamentos refletem uma postura ética provinda de um processo contínuo de auto-formação, de uma "briga contra si mesmo", já apontada pelo próprio Vinícius, na sua primeira antologia de poemas, em 1949. ${ }^{234}$

Em sua "Advertência", texto que antecede seus poemas, o poeta divide sua obra em duas partes: "a primeira, transcendental, freqüentemente mística, resultante de sua fase cristã" que "termina com o poema 'Ariana a mulher', editado em 1936"; e a segunda, em que "estão nitidamente marcados os movimentos de aproximação do mundo material, com a difícil, mas consistente repulsa ao idealismo dos primeiros anos"235.

O paradoxal distanciamento apaixonado de Orfeu ao desconsiderar as noções de perdão e culpa, temidos por Eurídice, pode ser tomado como um dos exemplos dessa "aproximação do mundo material", que afasta o que o crítico Otávio Melo Alvarenga denominou "'consciência do pecado' ", uma "constante da primeira fase [representada, por O caminho para distância]", que, segundo Renata Pallotini, "já aparece um pouco diluída, como um sentimento de culpa afastado no tempo [em Forma e exegese]" até atingir o "equilíbrio entre erotismo e pureza" [em

\footnotetext{
${ }^{234}$ Moraes, Vinícius de. Vinícius de Moraes: In: Poesia completa e prosa: volume único/ org. Eucanaã Ferraz. - Rio de Janeiro: Nova Aguilar, 2004. - (Biblioteca Luso-brasileira ; Série brasileira), p. 364.
} 
Novos poemas ], "paradoxalmente" chegando "ao platonismo", ${ }^{236}$ que, penso, também está sugerido em Orfeu da Conceição, sobretudo pela canção Se todos fossem iguais a você, conforme mencionei na apresentação das canções da peça.

O início do distanciamento crítico frente a questões cristãs, presente na peça, está também, por exemplo, no poema "O dia da criação". Como podemos verificar a partir da conclusão a que chega o crítico Eucanaã Ferraz:

[...] sem recusar a cosmogonia, obra exemplar de Deus, o poema realiza-se como sua irônica correção. Apesar de sua temática religiosa, de seu desejo de harmonia e de absoluto, "O dia da criação", marcado pelo tom coloquial, pela ironia e metalinguagem, em tudo difere da atmosfera reverente, da gravidade e da angústia conformadoras de poemas como "O caminho para a distância" e "Forma e exegese". ${ }^{237}$

O desempenho órfico, ou seja, o equilíbrio pessoal entre a razão e sentimento, harmonia e paixão, espírito e vida, na obra poética de Vinícius de Moraes, merece uma análise detida, que, neste momento, vai além dos limites deste trabalho. Mas como alusão, valho-me de alguns exemplos sugeridos pelas análises, pontuais, de Eucanaã Ferraz, cujo enfoque visa a "questões ligadas aos temas essenciais e às opções formais da obra de Vinícius". [grifos meus].

Como o crítico observa:

[...] em seus primeiros livros - O caminho para a distância [1933] e Forma e exegese [1935] -, Vinícius empregou o verso livre conquistado e consolidado pelos modernistas, de modo antimodernista: retórico, empostado [...] e, adiante, quando adotou um posição francamente moderna, passou a fazer uso constante de expedientes bastante tradicionais, como metrificação e forma fixa. Além disso, nesse momento, permanecem algumas constantes temáticas, mas tudo surge renovado, tratado com grande liberdade.

\footnotetext{
${ }^{236}$ Melo Alvarenga, Otávio. Apud. Pallotinni Mitos e valores, Rio de Janeiro: INL,1956, p. 158. Pallotinni, Renata. "Vinícius de Moraes: Aproximação" in: Vinícius de Moraes: poesia completa e prosa: volume único/ (Org. Eucanaã Ferraz). Rio de Janeiro: Nova Aguilar, 2004. - (Biblioteca Luso Brasileira; Série Brasileira), p. 138-9.

${ }^{237}$ Ferraz, Eucanaã. Vinícius de Moraes/Eucanaã Ferraz. São Paulo: Publifolha, 2006. (Folha explica), p.18.
} 
A liberdade associada à métrica e à forma fixa, percebida pelo crítico, pode ser relacionada à fusão entre a paixão dionisíaca e a harmonia apolínea, onde se inclui, como vimos, a linguagem popular e culta, os diálogos em versos de diferentes métricas, a canção popular etc.

Servindo-me ainda das análises dos poemas de Vinícius feitas por Eucanaã Ferraz, penso que sua conclusão sobre "A bomba atômica" ilumina também a maneira pela qual Vinícius toca, em Orfeu da Conceição, as misérias humanas:

Se, em todo o poema, o lirismo parece exacerbado, este exagero é, sem dúvida, a sua medida justa: o lirismo deve estar em seu ponto máximo, ultraconcentrado, porquanto visa a neutralizar o seu contrário. Os versos parecem mesmo arregimentar forças, daí reconhecermos aqui e ali a presença de "aliados" como Castro Alves, Cruz e Sousa, Augusto dos Anjos, Manuel Bandeira, mas também todo o arsenal do cancioneiro popular, das quadras anônimas às valsas e modinhas da época. Desse modo, convertida em arma, a máquina ultralírica do poema transforma a "bomba atômica" em "deusa", "mulher", "flor", "arcanjo", signos tática e generosamente cercados de ternura. A força destruidora da "bomba atômica" acaba por ser imobilizada pelo amor, acionado como um expediente que destrói o ódio embutido no símbolo máximo do poderio bélico moderno. ${ }^{238}$ [grifo meu].

Nota-se aí o compromisso ético, a auto-formação constante, que compõe todo o percurso do poeta, continuando a "briga" em "si mesmo", briga de Orfeu contra a "cidade", adversária a isso.

238 Idem, p. 24 
[Vinícius de Moraes]

Presenças de Orfeu: Vinícius de Moraes e Carlos Drummond de Andrade

Como vimos, Orfeu harmoniza duas forças bastante diversas: apolíneas e dionisíacas. Seu comportamento em relação aos dois deuses é de proximidade e distância, também. Com Apolo, o deus da harmonia, o músico conheceu a lira, a qual acrescentou mais duas cordas; de maneira semelhante a Dionísio, desceu ao Inferno e foi despedaçado, e por causa desta experiência comum, modificou os rituais do deus do vinho, excluindo o sacrifício de animais. De forma bastante reduzida, como todo esquema, podemos associar as características apolíneas à contenção, e as dionisíacas ao transbordamento.

Se pedíssemos aos leitores de Drummond e Vinícius que relacionassem esses dois termos à obra dos dois poetas, provavelmente teríamos a contenção identificada à obra de Drummond e o transbordamento à de Vinícius, sobretudo porque obra e vida, em um procedimento genérico como este, confundem-se ainda mais: a expansão das praias cariocas misturadas ao costume de Vinícius de deixar as portas de sua casa sempre abertas, para que os amigos pudessem entrar sem precisar bater ${ }^{239}$; e a introspecção das montanhas mineiras refletindose no pedido de Drummond à esposa para que mentisse dizendo a amigos que ele não estava em casa, enquanto se escondia em algum canto ${ }^{240}$, ajudam a promover essas imagens, relacionadas também ao lugar de origem desses poetas.

Mas essa impressão ganhou para mim um novo movimento, depois de analisar as retomadas de Orfeu por Carlos Drummond de Andrade e por Vinícius de Moraes. Tanto em "Legado" - onde Orfeu caminha taciturno entre o "talvez e o se", enfrentando "esses monstros atuais" -, como em "Canto órfico" - onde ele também caminha, neste momento de modo subliminar, até ser evocado com

\footnotetext{
${ }^{239}$ Castello, José. O poeta da paixão: uma biografia. São Paulo: Companhia das Letras, 1994.

240 Cançado, José Maria. Os sapatos de Orfeu: biografia de Carlos Drummond de Andrade, São Paulo: Globo, 2006.
} 
euforia -, o que se evidencia é o pulsar da vida, a paixão que, latente, expressa-se em todo o seu vigor. O que se evidencia é o sentimento, que atravessa e compõe o saber apolíneo trazendo consigo as lembranças do poeta, efetivadas no poema.

As representações apolíneas são marcantes: em "Legado", a opção pelo soneto - com rimas e métrica constante -, principalmente a retomada do verso da época de seu "estilo mesclado"241, adaptando-o à forma clássica, assim como os decassílabos, em "Canto órfico", confirmam isso, mas a força contraposta ao mundo dos monstros atuais, verdadeiros rivais de Orfeu, não é a das "artes pétreas", apolíneas, mas a do "verso universo latejante" dionisíaco que desponta da experiência da morte, do amplo vazio, "que sabendo das trevas elementares, se dedica às obras do dia"242; que parte do reconhecimento do valor da memória para a vida do próprio poeta e das pessoas a quem seus poemas são dirigidos. Paradoxalmente, a introspecção do poema gera, no leitor, a identificação com o poeta e, nesse sentido, o que parecia um movimento para dentro, é percebido como extroversão, mesmo que latente (ou justamente porque é latente, comprovando a vida interior, do que não se mostra externamente). Ao fim e ao cabo, o que resulta está mais próximo à comunhão dionisíaca, identificada à vida na terra, do que à espiritualidade apolínea; está mais próxima ao esplendor sensível do que à idéia.

Na peça de Vinícius, por outro lado, é o desejo pela expressão da harmonia apolínea que parece mover o Orfeu da Conceição. Sua força não vem da constatação agônica da falta do canto órfico, drummondiana, mas do desejo idealmente forjado no próprio canto que se realiza, como canto de Orfeu. Os versos metrificados e as rimas desaparecem, quando o cantor perde Eurídice e deixa de cantar, quando ele desce para a cidade, identificada ao Clube dos

\footnotetext{
${ }^{241}$ A expressão é de José Guilherme Merquior,. Verso universo em Drummond; trad. Marly Oliveira. Rio de Janeiro: José Olympio, Secretaria de Estado de Cultura, Ciência e tecnologia, 1975.

${ }^{242}$ O trecho entre aspas é de Anathol Rosenfeld comentando o caráter binário dos heróis de Thomas Mann, identificados a Dionísio, que por extensão é tomado aqui como característica também de Orfeu. O crítico observa que: "Despedaçados pela crise, eles [ou seja, os heróis de Thomas Mann, binários como Dionísio]ressurgem da tumba hermética (que também pode ser a montanha mágica) para uma nova vida que sabendo das trevas elementares, se dedica às obras do dia". Texto e contexto. Op. cit., p.211.
} 
maiorais do Inferno. O seu intuito, ao compor as canções, é dirigido ao arranjo, à acomodação da emoção da vida pulsante do morro à harmonia da melodia.

Ambos, como Orfeu lidam com essas duas forças de Apolo e Dionísio

Os versos de Drummond, na sua própria expressão da falta ${ }^{243}$, evidenciam visceralmente a necessidade da procura constante de uma melodia - da "cifra" adequada, (identificada também ao Velocino de ouro dos argonautas) como buscava Orfeu -, que realmente seja capaz de vencer os "monstros atuais", transformando-se realmente numa "rosa trismegista aberta ao mundo". Sua alusão a Orfeu provém da inequívoca constatação do vazio.

A peça de Vinícius representa a celebração ("O morro é Orfeu") do encontro entre as forças apolíneas e dionisíacas contrárias ao mundo, embebida, por sua vez, na realização das canções que atravessam de maneira singular este adversário. O encontro entre Vinícius e a cultura popular do morro expressa a síntese do nascimento do poeta e cantor, um outro Orfeu, capaz de abraçar também as contradições e fazer o seu caminho particular.

Assim, tanto, a peça com suas canções produzidas por Orfeu, como os poemas de Drummond, tocam, cada um a seu modo, o mundo avesso aos mitos.

Tanto os Orfeus de Drummond quanto o Orfeu da Conceição de Vinícius resistem ao mundo dos "monstros atuais" indiferentes à expressão dos poemas e das canções. Essa resistência - enquanto característica que revela um comportamento ético frente ao mundo, expresso esteticamente pela poesia -, identifica-se à Aretê grega relacionada, por sua vez, à idade de ouro. Mesmo que, no canto, este princípio de auto-formação esteja em oposição aos valores consagrados pelo mundo das mediações, a poesia/obra identificada com este princípio, como as analisadas aqui, traz-nos aquela luz de Homero, que não se apaga nunca.

${ }^{243}$ Tão presente e tocante no poema "O elefante". 
Os filmes de Marcel Camus e Carlos Diegues expressam, também, cada um a seu modo, essa "cidade" da peça de Vinícius de Moraes, que identifico aos "monstros" sempre "atuais" sugeridos pelo poema de Drummond. Orfeu negro talvez nos aponte um dos grandes problemas relacionados ao Brasil: chegar aos avanços do mundo moderno, sem perder o que temos de origina ${ }^{44}$; em Orfeu, de Diegues talvez vejamos a urgência de responder essa questão.

Próximo de Apolo, mas de Dionísio também, forças cujo potencial pode ser encaminhado tanto para a beleza das artes, quanto para a perversão dos melhores sentidos, tanto para a harmonia fluida, quanto para a rigidez, Orfeu é o equilíbrio entre essas forças em constantes mudanças, em todas as épocas, que, combinadas a seu modo pacífico, torna-o capaz de encantar o que está a seu redor transformando os excessos do mundo, sensível à nota certa a ser ouvida por cada um que deve ou precisa ser tocado.

Orfeu dividido entre Apolo e Dionísio forja a sua própria escolha. Não se perde entre as diferenças, pelo contrário, se constrói nelas e passa a criar. Não é comandado, mas comanda, orienta o caminho dos argonautas, sem deixar que abandonem o desejo de recuperar o que perderam.

Produto do homem que sabe que vai morrer, mas não se mata, deixando o mundo para trás, o canto de Orfeu chega a nós como presente divino e conselho ao mesmo tempo, sensação de eternidade, que só quem passa pelo sentido total da perda ou pelo pressentimento dela pode sugerir; presente divino que continua como filtro do mundo transformado em palavras e melodia, que, juntos, chegam à harmonia.

Nos tempos atuais, das medalhas incertas (geradoras talvez, tanto da síntese do "fui" - daquele que ainda nem bem chegou -, como da expressão "da vez": jogador "da vez", cantor "da vez", poeta "da vez", o próximo a ser engolido pela caçapa), quando a vida íntima parece às vezes não existir, ou quando sem lugar, ela perde-se na multidão de desejos de outros, passando a não ter sentido para ninguém, quando as diferenças não produzem mais a troca, mas diferentes forma de morte, Orfeu precisa existir.

${ }^{244}$ Cf.: Hollanda, Sérgio Buarque de. Raízes do Brasil. São Paulo: Companhia das Letras. 
Tanto a atitude do Orfeu da Conceição frente a julgamentos de valor, como a mudança do sentido comum das palavras, do sentido estático do dicionário, ocorrida em "Legado" e em "Canto órfico", ou ainda a introspecção do "eu lírico", o voltar-se a si mesmo promovendo sua ação, apontam um nadar contra a corrente dos valores estabelecidos - ideológicos -, atitude possível só àqueles que contrariando a maré ainda conseguem ter vida em si mesmo, aqueles que têm paixão, principalmente.

Post scriptum

Drummond tinha apenas treze anos, no início da Primeira Grande Guerra; Vinícius, três. Em um dos poemas de Boitempo, ele recupera a lembrança da infância sobre esse período: "Desta guerra mundial/ não se ouve uma explosão/ sequer nem mesmo grito/ do soldado partido/ em dois no campo raso.[...] Vem tudo no jornal/ ilustrado, longínquo".

Depois da Primeira e Segunda Guerras Mundiais é impossível a quem quer que seja desconsiderar esse fracasso humano, é impossível aos poetas não questionar a validade de suas criações, não colocar em dúvida a validade de aludir a uma ordem dentro do caos ou de expressar uma ordem singular dos poemas, tão própria ao jogo metafórico (que não deixa de ser lúdico). Entusiasmados pelas reivindicações do Partido Comunista, tanto Drummond como Vinícius aproximaram-se dele, mas ambos tiveram suas expectativas malogradas. $^{245}$

O fundamental na atitude dos dois poetas ajusta-se muito bem à análise de Olgária Matos sobre um personagem do filme Amantes constantes, de Philippe Garrel,

\footnotetext{
${ }^{245}$ Cf., entre outros capítulos, "Nem Tomás, nem Stálin, nem Freud" e "O partido atrás da porta", in: Cançado, José Maria. Os sapatos de Orfeu: biografia de Carlos Drummond de Andrade. Op. cit. e Castelho, José. O poeta da paixão: uma biografia. Op. cit.
} 
Trágicas, as personagens do filme, em meio a ações consumadas, vivem os combates com a lúcida consciência que previne $o$ ato de ser ausência de pensamento. Assim, quando um dos jovens está fugindo da polícia, [em maio de 68] e um "ativista" repassa um coquetel molotov para que ele atire na viatura de polícia onde se encontram os CRS, ele pensa que seu gesto vai matá-los, abandona a arma e se abstém. Como em L'Espoir, de André Malraux, de nada vale a "ética da responsabilidade" - a do "político" e sua "razão de estado", a do aprendiz de assassino que deve matar em nome da causa e do partido -, mas vale a dos princípios, a da moral individual e subjetiva que é, melhor dizendo, a autonomia [grifo meu]. ${ }^{246}$

246 "Paris 1968: polis contemporânea: no filme Amantes constantes, o ano presente em todos os movimentos contrários ao status quo", in: O Estado de São Paulo, 15.10.2006,Caderno Cultura, "Cinema ensaio", p.7. 
Trechos de correspondências, entrevistas e relatos envolvendo os dois poetas: Carlos Drummond de Andrade e Vinícius de Moraes.

$1-$

Apesar das queixas e dos conselhos que lhe davam, por exemplo João Cabral de Mello Neto, insistindo para que ele se dedicasse mais à literatura, Vinícius voltava-se para a criação de canções. Já diabético e depois de algumas internações hospitalares por causa do excesso de consumo do whisk, volta e meia, ele comentava com os amigos mais próximos sobre o livro que preparava. Chegou a mostrar a Toquinho "alguns manuscritos de $O$ deve e o haver, seu testamento poético, em que trabalhava fazia quase vinte anos"247. Infelizmente, embora o parceiro tenha se empenhado em achar esses manuscritos, procurando-os por "todos os cantos da casa" de Vinícius, nada foi achado.

\section{2-}

Drummond expressou sua vontade de compor um poema musical, como Os sonhos de uma noite de verão de Shakespeare.

3-

"[...] Vinícius passou a vida preocupado a sua maneira, usando meios próprios de expressão, com o problema do destino e da finalidade do homem. Para ele, a princípio, essa finalidade consistia na identificação com o absoluto. Depois, com o tempo e para sempre, com o amor, que compreende uma vida social e individual fundada na justiça e na paz. A plena realização do amor era, a seu ver, a razão da vida. E a poesia era o meio de tomar conhecimento e de espalhar essa verdade. Sua vida foi a ilustração de seu ideal poético. Ele queria o mundo preparado para o amor, livre de limitações, pressões e obrigações sociais e econômicas. Ora, um ideal dessa natureza é certamente eterno.

247 Castello, José. O poeta da paixão. Op. cit., p.428. 
Vinícius defendeu-o com muita eficácia, quer na poesia pura, quer na poesia em forma de música.

Ele não teve uma vida regulamentada por padrões burgueses. Daí não se poder cobrar dele atitudes formais. Para mim, o grande mérito de Vinícius, foi conseguir conciliar a poesia erudita com a música popular. Sentiu que esse era o caminho para tirar a poesia do gabinete, do laboratório. Era uma pessoa encantadora, gentilíssima e não se considerava superior a ninguém, ao contrário de muitos artistas que se cultivam como mito.

Eu fui ao enterro por um dever de gratidão e amizade. Não gosto de enterros, gosto de ver os amigos vivos, dialogar com eles, trocar impressões, rir juntos. É um absurdo o desaparecimento físico de Vinícius de Moraes, o maior poeta de sua geração. Mas ele sobe para ficar como uma estrela no céu." [texto de Drummond de Andrade, transcrito em Vinícius, sem ponto final, de João Carlos Pecci. São Paulo: Saraiva, 1994, p. 95]. [grifos meus]

4-

"Mas mesmo essa condição meio esquisita de Barnabé em armas não impediu que Drummond experimentasse alguns momentos de emoção autêntica. Ele gostava de lembrar o surrado verso de Vinícius para referir-se aos acontecimentos. Aquilo tinha sido bom enquanto durou, costuma dizer. Principalmente nos dias em que esteve em Barbacena, na espera de um combate decisivo que se travaria numa garganta da serra da Mantiqueira entre as tropas revoltosas federais aquarteladas em Juiz de Fora.

Não houve combate algum, mas não foi tão ruim esperar por ele. 'A existência ficou sendo um poema bélico ligeiramente dançante', dizia ele, ao falar dos dias em Barbacena [...] 'Ali o ar cheirava a rosas, as noites eram calmas e dançantes...Barbacena é uma das boas recordações da minha vida de burocrata'" [José Castello.Os sapatos de Orfeu, op. cit., p. 142].

$5-$

"Mas o que mais o impressionou nos primeiros dias, gentileza pontilhando as suas noites cariocas de recém-chegado, foi o som de um cavaquinho, "modesto e criativo", que vindo do morro da Babilônia, que fica quase debruçado sobre onde era uma vila, descia 
até a sua casa. Ele registrou isso num de seus primeiros poemas escritos no Rio, "Morro da Babilônia" [texto sobre as primeiras impressões de Drummond ao vir morar no Rio de Janeiro. Os sapatos de Orfeu, op. cit., p. 151].

$6-$

"Caetano encontrou Drummond no casamento de Suzana de Moraes, filha de Vinícius [...] 'Caymmi é incrível, aquele homem dá sempre a impressão de estar sempre de bem com a vida", comentou Drummond [...]. Caetano então Ihe contou que o próprio Caymmi tinha dito para ele: 'Você sabe que o Caymmi, outro dia disse que sentava numa cadeira de balanço, vinha a brisa, batia, e ele ficava assim, só pensava em coisas boas'. Drummond respondeu: 'E nós, Caetano, que só pensamos em coisas ruins...'. Eles tinham chegado a Dorival Caymmi a partir do assunto inicial da conversa. Drummond via uma 'qualidade de felicidade' na música popular, na poesia cantada, e que não via na poesia escrita. Uma 'certa felicidade' que ele não reconhecia dada assim na poesia que poetas como ele faziam.

Era nisso, nesse primado da 'felicidade' na poesia, que Carlos Drummond de Andrade pensava quando foi ao enterro do próprio Vinícius de Moraes em junho de 1980. Foi o que tentou dizer, aturdido, à repórter de televisão (foi a sua primeira grande entrevista na televisão). 'Era o único poeta que vivia como poeta', disse. Para outras pessoas, ele já tinha dito: 'Vinícius é que está certo, faz essas coisas às claras'.

Drummond apareceu de barba no enterro. Barba branca. Antes que as pessoas Ihe perguntassem alguma coisa, ele ia dizendo a cada uma, rápido, de supetão: 'Estou com herpes, não pega'. Ele tinha sido atacado pelo herpes zoster, um vírus insidiosíssimo, que se aproveita da baixa resistência do sistema imunológico das pessoas para se instalar no organismo, e cuja ação, principalmente nos nervos da face, provoca dores horríveis (daí a impossibilidade de Drummond fazer a barba)." [José Castello. Os sapatos de Orfeu, op. cit., p. 325].

7-

"Ele tem o fôlego dos românticos, a espiritualidade dos simbolistas, a perícia dos parnasianos, (sem refugar, como estes, as sutilezas barrocas) e finalmente, homem bem 
de seu tempo, a liberdade, a licença, o esplêndido cinismo dos modernos" [Drummond sobre a poesia de Vinícius, in: O poeta da paixão, op. cit., p. 15].

$8-$

"Drummond disse dele uma definição inapelável 'Foi o único entre nós que teve uma vida de poeta'”. [José Castello. O poeta da paixão, op. cit., p. 15]

$9-$

“Já numa crônica que escreve em 1945 sobre o vermelhinho, o poeta destaca 'até os mais enrustidos, como Manuel Bandeira, Carlos Drummond de Andrade, Astrogildo Pereira e Aníbal Machado' freqüentam o Vermelhinho." [José Castello. O poeta da paixão, op.cit., p. 160-1]

$10-$

"Drummond estava certo: autor de alguns dos poemas mais belos da língua portuguesa, Vinícius de Moraes espalhou sua poesia pela realidade. Fez da poesia vida. 'Atuou' magnificamente, como poeta. Provou que a autenticação de um poeta não é dada somente pelos versos que escreve, mas pelo olhar poético com que é capaz de envolver o mundo a seu redor. Ampliou, assim, o conceito de poesia retirando-o do domínio do restrito dos gêneros literários e espalhando-o pelo mundo real." [José Castello. O poeta da paixão, op. cit., p. 17]

$11-$

"Um dia, nos estúdios da gravadora Continental, o poeta lhe diz, com a naturalidade de quem pede um objeto emprestado: 'Paulinho, estou precisando de um maestro, que me ajude numas músicas que vou fazer. Você tem algum?' Paulinho Soledade responde de pronto:'Tom Jobim', e daí se contém um pouco, mas prossegue: 'Tem um problema, ele é moderno. Bebe bonito, conhece poesia e passa a madrugada lendo Drummond. Pode ser perigoso...' Vinícius, feliz, não o deixa prosseguir : 'Mas é um 
sujeito exatamente assim que eu quero'. " [José Castello. O poeta da paixão, op. cit., p. 186]

$12-$

"Com seus amigos paulistas, se permite certos tipos de confidência que, no Rio, são impensáveis. Zequinha ouve dele um desabafo como esse "Cansei de falar para o Drummond que ele tem que se aproximar mais da vida". Lamenta. "Eu sei que ele inveja esse meu lado promíscuo com a realidade. Mas não consegue sair de seu casulo". Carlos Drummond de Andrade, poucas semanas depois, como que respondendo ao amigo, declara mais uma vez: 'eu invejo o Vinícius porque ele vive em estado permanente de poesia." [José Castello. O poeta da paixão, op. cit., p. 296]

$13-$

"Não gosta, porém quando os estudantes começam a tratá-lo como um 'poeta político'. Numa entrevista, explica: 'Não adianta você querer fazer poesia política de propósito. O poema tem que nascer da tua revolta'. Num momento em que está mais exaltado, reclama: 'Não vou fazer como o Drummond, que leva os poemas dos comunistas para casa e os corrige, para que fiquem mais bonitinhos. Não sou revisor de comunista'. E quase aos berros, revela: 'Eu fiz muita poesia política e rasguei tudo depois. Vi que elas não tinham verdade nenhuma. Eram só artifício. Quando Ihe perguntam sobre “O operário em construção' o poema radical concluído em Paris, em 1955, depois de três anos de trabalho, que chegaria depois a ser lido como homilia numa missa dos metalúrgicos petistas do $A B C$ paulista, explica: 'Esse não é um poema político, é um poema visceral. Poema político é aquele que você faz de encomenda'. E já tomado pelo mau humor, arremata: 'A razão pode ser a mais digna possível, mas não me peçam isso. Não faço poemas para fora" [José Castello. O poeta da paixão, op. cit., p. 355]

$14-$.

"No início dos anos 70, o chileno Pablo Neruda faz uma visita a São Paulo e se encontra com Vinícius num almoço [...] Depois de alguns drinques, Toquinho acompanha Vinícius ao violão. Neruda, num rasgo de sinceridade, confessa: 'Não tive a coragem do 
Vinícius. Era o que eu mais gostaria de ter feito: letras de música. Mas tive medo de que me desprezassem'. Vinícius não consegue esconder sua emoção, pois sempre considerou Pablo Neruda o maior poeta vivo de nossa época". [José Castello. O poeta da paixão, op. cit., p. 296]

$15-$

Trecho de Carta de Di Cavalcanti para Vinícius de Moraes:

"[...] P.S. Você perdeu uma macumba em Oswaldo Cruz terça-feira passada. Passamos a noite lá, eu, Carlos Drummond, Onestaldo [de Pennafort], Carlos Cavalcanti e um preto fabuloso chamado Heitor ["Pela descrição, o sambista e pintor naïf Heitor dos Prazeres"]"248 [4.10.37] [Querido poeta, correspondência de Vinícius de Moraes. Org. Ruy Castro. São Paulo : Companhia das Letras, 2003, p. 51.]

$16-$

Trecho de Carta de Vinícius para Drummond:

"Carlos,

Venho the amolar novamente com aquele meu velho protegido, o dr. Raimundo Lemos (o que tem uma cara trágica e uma cabeça quase branca), que levei uma vez a você. Este rapaz, coitado, velho amigo dos tempos de moleque de praia em Copacabana, está envelhecendo numa luta sórdida para se colocar 'em algum lugar do Brasil'. É incrível! Nunca vi ninguém tão desprotegido. Falta-lhe praticamente tudo - porque, além do mais, ele tem uma noivinha com quem quer casar, sem poder. [...] Enfim, você me desculpe a maçada, e este vício que eu tenho de lhe pedir favor. É uma espécie de irremediável confiança no seu espírito e no seu coração.

Seu, Vinícius [...]".[Rio, 20 de julho de 1942] [Querido poeta, op. cit., p. 105.]

$17-$

Trecho de carta de Drummond para Vinícius: ${ }^{248}$ Nota de Ruy Castro; organizador de Querido poeta : correspondência de Vinícius de Moraes.
Op. cit. 
"Vinícius, aí vão seus poemas [Cinco elegias]. Você é realmente 'o tal', pela pureza do lirismo e pela economia e força de expressão. Quanta coisa se aprende em seus versos! Certos arranjos de palavras são verdadeiros achados. E há em tudo uma limpidez que torna sua poesia como que transparente, fluida. Confesso a você que nada é mais belo para mim do que conseguir tirar todo o peso de uma palavra, torná-la aérea, diáfana. Você faz isso a cada instante. Fiquei cheio de admiração, de alegria e de inveja, numa mistura explosiva. Obrigado pela leitura prévia.

Anotei a lápis algumas coisas que me parecem descuidos de revisão. Se tiver dado algum palpite errado, desculpe. [...]

Um abraço do

Carlos" [ Rio, 14 de fevereiro de 1944] [Querido poeta, op. cit., p. 110.]

$18-$

"Carlos querido,

Notei com alegria, depois do poema pronto, uma saudável aragem de tua poesia correndo por ele. O Rubem [Braga] objetou ao 'espasmo do piloro'. Não sei. Foi feito depois de uma visita a um amigo que tinha acabado de perder o filhinho.

Um grande abraço.

Vinícius." [Rio, 16 de junho de 1944] [Querido poeta, op. cit., p. 111.] $19-$

Trecho de carta de Vinícius para Raul Bopp :

"[...]Gostei de Los Angeles de cara, apesar de ter chegado meio amarrotado [...]Mas foi bom porque [...] gravei um disco do Carlos Drummond de Andrade, no Poetry Room de Harvard e cedi ao paraísmo ["relativo ao 'exército do Pará' , mais uma categoria na classificação de Ovalle e Schimidt. Referia-se aos que vinham para o Rio (não necessariamente do Pará) dispostos a tudo para vencer.] ${ }^{249}$ [ Los Angeles, 19 de julho de 1946] [Querido poeta, op. cit., p. 116.]

${ }^{249}$ Idem. 
Trecho de carta de Vinícius de Moraes para Manuel Bandeira

"Escrevi, faz pouco, uma carta grande para o Rodrigo [Mello Franco de Andrade], mas acho que ele não recebeu, porque até agora, abacate. Nela eu, inclusive, pedia a ele para se comunicar com o Carlos [Drummond de Andrade] no sentido de uma autorização para transcrever o "Canto ao homem do povo Charles Chaplin", na revista de cinema que estou fazendo com o Alex Vianny, e que deve aparecer aí em fins de outubro[...]." [Hollywood, 14 de setembro de 1947] [Querido poeta, op. cit., p.128]

22-

Trecho de carta de Vinícius para Lauro Escorel,

“ Los Angeles, 7 de setembro (!) de 1949.

[...] A atitude dos que colocam a atividade criadora num plano tão alto como o da salvação da sociedade, ou a garfada na boca de um simples indivíduo, me é hoje totalmente estranha. Não entendo a atitude de Carlos [Drummond de Andrade], e de Manuel [Bandeira] e de outros - amigos muito queridos, que não quero ferir e cuja amizade não quero perder. Só me resta a malícia, que a vida em poesia me ensinou, até o momento do show-down, que se aproxima. Mas, até o show-down, não serei eu que levantarei a mão contra os que me amaram pelo que eu sou. No próprio show-down, não sei se levantaria a mão. Só sei ser violento contra fascista, contra homem que despreza seus semelhantes, contra o ser execrável que diz entre dentes: 'o negro...', ‘o judeu...' ‘o mexicano ....'

Não há nada que eu preze hoje em dia mais do que a cordialidade humana. Faço freqüentemente desculpas pelos erros dos outros, e sou capaz de chegar a extremos incríveis para ver um ambiente humano viver o seu curto contato, e contágio, sem ódio. Coisa difícil é relação humana e, no entanto, nada há mais importante [...]" [Querido poeta, op. cit.,p.159-61] 
"Carlos,

Por favor, vê se esse poema pode sair no suplemento de domingo, pois estou com gaita curtíssima. Se te for possível receber por mim, please...

O Vinícius." [Rio, 30 de Agosto de 1951.] [Querido poeta, op. cit., p.187]

24

Trecho de carta de Vinícius para Drummond

Soube que você falou para a TV Globo uma coisas simpáticas a meu respeito, no dia dos meus sessenta, que infelizmente não ouvi porque tinha uma repórter me entrevistando - sabe, uma dessas menininhas de redação, sempre de gravador em punho - e, quando me chamaram, já tinha terminado. Fiquei com ódio dela.

Quando escrever para Julietinha, dê-lhe um grande abraço meu. Gosto muito dela. Aliás, não sei se ela está por lá ou por aqui, porque me disseram que estava no show com você. Foi pena vocês não terem vindo até as coxias, gostaria muito de tê-la visto nem que fosse um pouquinho. E a você também, é claro, porque você é uma pessoa a quem eu quero muito bem. [...]".[Salvador (Itapoã), 24 de janeiro de 1973.] [Querido poeta, op. cit., p.339-40]

25-

Carta de Carlos Drummond para Vinícius :

"Poeta querido,

Quando você foi operado, eu iniciava uma estação de herpes zoster na cara que até hoje não terminou e que me chateia muito. Por isso não pude visitá-lo, mas pedi a Dolores que telefonasse para a Casa de Saúde, transmitindo os nossos votos de recuperação rápida e total. Continuo malacafento, mas tenho notícias boas de você, por amigos comuns, e isso me alegra. Aqui vai o meu abraço de antiga, funda e meio silenciosa amizade, com todo o carinho da turma - Dolores e Maria Julieta [mulher e filha de Drummond]. Você é tão importante para nós todos, desta casa e do Brasil verdadeiro, 
que ficamos ansiosos por vê-lo de novo em atividade poética e musical. Dê essa alegria pra gente, vamos!

Seu velho e fraterno,

Carlos". [Rio, 23 de junho, de 1980.] [grifo meu] [Querido poeta, op. cit., p.352] 
BIBLIOGRAFIA:

Sobre o mito de Orfeu e Mitologia:

BRICOUT, Bernadette. Olhar de Orfeu: os mitos literários do Ocidente.São Paulo: Companhia das Letras, 2003.

CAMPBELL, Joseph. O poder do mito com Bill Moyers. (Trad.Carlos Felipe Moisés), São Paulo: Associação Palas Athena, 1980.

Isto és tu.(Trad. Edson Bini), São Paulo: Landy, 2002. CARVALHO, Silvia Maria. (org.) Orfeu, Orfismo e outros heróis. São Paulo: Unesp, 1990.

CORRAL, Luis Diez. La funcion del mito clasico. Madrid: Editorial Gredos, 1957.

DEBS, Sylvie. Cinema et Litterature au Brésil : les mythes du Sertão émergence d'une identité nacionale. Paris: Harmattan, 2002. DETIENNE, M. A escrita de Orfeu. (Trad. Mário da Gama Kury). Rio de Janeiro: Jorge Zahar Editor, 1989.

DETIENNE, Marcel. Dionysos à ciel ouvert. Paris : Hachette Littératures, 1998.

Les dieux d'Orfée. Paris : Gallimard, 2007.

DIEL, Paul. Le symbolisme dans la mithologie grecque. Paris: Petite Bibliothèque Payot, p. 14.

DODS, E.R. Les grecs et l'irrationnel.. France :Flammarion, 1977.

DURAND, Gilbert. Introduction à la mythologie. Mythes et sociétés. Paris : Editions Albin Michel, 1996.

ELIADE, M. Aspects du mythe. Paris: Gallimard, 1963.

Mito e realidade. $6^{\circ}$ ed., São Paulo:Perspectiva

HAMILTON, Édith. La mythologie: ses dieux, ses héros, ses légendes. Belgique : Marabout, 1978.

JACQUEMARD, Simonne et BROSSE, Jacques. Orphée ou l' initiation mystique, Paris : Bayard ditions, 1998.

Orphée Poemes magiques et cosmologiques.(Collection: Aux sources de la tradiction). Posfácio : Luc Brisson. Paris: Les Belles Lettres, 1993. 
JAEGUER, Werner. Paidéia: a formação do homem grego. (Trad. Artur M. Parreira). São Paulo: Editora Herder [s/d]

SOREL, Reynal. Orphée et l'orphisme (Que sais-Je) $1^{\mathrm{a}}$. ed., Paris: Presses universitaires de France, 1985, p. 17.

TROUSSON, Raymond. Thèmes et mythes: questions de méthode. Bruxelles: Editions de l' Université de Bruxelles, 1981.

VERNANT, Jean-Pierre \& VIDAL-NAQUET, Pierre. Mito e tragédia na Grécia antiga I e II. São Paulo: Perspectiva, 1999 (Coleção Estudos: 163)

VERNANT, Jean-Pierre. O universo, os deuses, os homens: mitos gregos contados por Jean-Pierre Vernand. São Paulo: Companhia das Letras.

Sobre "Legado", "Canto órfico", Orfeu da Conceição e/ou seus autores:

ANDRADE, Carlos Drummond de. Reunião (10 livros de poesia). $3^{\mathrm{a}}$. ed. Rio de Janeiro: Livraria José Olympio Editora, 1973, p. 165.

O observador no escritório. São Paulo:

Record, 1985.

ANDRADE, Mario. Vida literária. São Paulo: Edusp/Hucitec, 1993.

O banquete. São Paulo: Duas Cidades, 1977.

A lição de amigo. São Paulo: Record, 1987.

ARRIGUCCI, David. Coração partido. São Paulo: Cosac \& Naify, 2002.

BOSI, Alfredo. História concisa de Literatura Brasileira, $42^{\circ}$ ed. , São Paulo: Cultrix, 2004.

CAMILO, Vagner. Drummond, da Rosa do povo à rosa das trevas. $2^{\circ}$ ed.,São Paulo:Ateliê Editorial, 2001.

CANÇADO, José Maria. Os sapatos de Orfeu : biografia de Carlos Drummond de Andrade, São Paulo:Globo, 2006.

CANDIDO, Antonio. O Romantismo no Brasil. São Paulo: Humanitas, FFLCHUSP, 2002.

"As inquietudes de Drummond", in: Vários escritos. $3^{\circ}$ ed., 
São Paulo: Duas Cidades, 1995.

CARPEAUX, Otto Maria. "O sol de Homero", "Poesia e ideologia", "Fragmento sobre Carlos Drummond de Andrade", in: Origens e fins. Rio de Janeiro: Casa do Estudante, 1943.

"Estúdios sobre la poesia brasilenã. (México)

Cuadernos americanos: La revista del nuevo mundo. Ano 5, v. $3^{\circ}$, n.6, nov-dez. 1946.

CASTELLO, José. Vinícius de Moraes : o poeta da paixão/ uma biografia.. São Paulo: Companhia das Letras, 1994

FERRAZ, Eucanaã. Vinícius de Moraes/Eucanaã Ferraz. São Paulo: Publifolha, 2006; - (Folha explica).

GLEDSON, John. Poesia e poética de Carlos Drummond de Andrade. São

Paulo:Duas Cidades, 1981.

LIMA, Mirella Vieira. Confidência Mineira: o amor na poesia de Carlos Drummond de Andrade. São Paulo:Edusp, 1994.

MERQUIOR, José Guilherme. Verso universo em Drummond; Trad. Marly Oliveira. Rio de Janeiro: José Olympio, Secretaria de Estado de Cultura, Ciência e tecnologia, 1975.

MICHELETTI, Guaraciaba. A poesia, o mar e a mulher: um só Vinícius. São Paulo: Editora Escuta, 1994.

MORAES, Vinícius. Orfeu da Conceição: tragédia carioca. $2^{\underline{a}}$ ed. Rio de Janeiro: Livraria São José, 1960.

O cinema dos meus olhos. $2^{\mathrm{a}}$. ed., São Paulo:

Companhia das Letras, 1991.

Querido poeta : correspondência de Vinícius de Moraes / seleção, organização e notas de Ruy Castro. São Paulo: Companhia das Letras, 2003.

Cancioneiro Vinícius de Moraes, Orfeu: songbook/ músicas de Antonio Carlos Jobim \& Vinícius de Moraes. Rio de Janeiro: Jobim 
Music, 2003.

Poesia completa e prosa. Rio de Janeiro: Nova

Aguilar, 1986.

Poesia completa e prosa. Org. Eucanaã Ferraz.

Rio de Janeiro: Nova Aguilar, 2004

PALLOTINI, Renata. "Vinícius de Moraes: Aproximação." In: Moraes, Vinícius de. Poesia e prosa completa. Op. cit.

PARANHOS, Luiz Tosta. Orfeu da Conceição (tragédia carioca). Rio de Janeiro: Livraria José Olympio, 1980.

PECCI, João Carlos. Vinícius sem ponto final. São Paulo: Saraiva, 1994.

PRITSCH, Eliana Inge. "Orfeu e Drummond", in: Revista Ciências e Letras, Revista das Faculdades Porto- Alegrenses de Educação Ciências e Letras, n. 20, 1977.

VILLAÇA, Alcides. Lendo poetas brasileiros. Trabalho apresentado para 0 concurso de Livre-docência na FFLCH- USP, 1999, p. 5.

Passos de Drummond. São Paulo:Cosac \& Naify, 2006.

Sobre os filmes Orfeu negro, de Marcel Camus e Orfeu, de Carlos Diegues

AMÂNCIO, Tunico. O Brasil dos gringos : imagens do cinema. Niterói: Intertexto, 2000.

"O estrangeiro Marcel Camus: olhares do afeto sobre algumas cidades brasileiras", in: Passages de Paris 1, (2005). www. Apebf.org/passages AUGUSTO, Sérgio. "Ópera negra virou 'Macumba para turista'." In: Bravo! (Rio de Janeiro, maio de 92, ano 1, n.8, p. 95.

AUGUSTO, Sérgio. "Ópera negra virou ' Macumba para turista' “ In: Bravo! (Rio de Janeiro, maio de 92, ano 1, n.8, p. 95.

BANDEIRA, Manuel. "Orfeu do carnaval". In: Andorinha, andorinha. Rio de 
Janeiro: José Olympio, 1966, p.139-40.

BENTES, Ivana. "Nelson, Camus, Diegues: Retóricas do Nacional e o Popular."In: Cinemais-Revista de cinema e outras questões audio-visuais. (Rio de Janeiro, 26. nov-dez.2000, p.83-97.

BRAZ, Camilo D’Angelo. As representações do Imaginário : uma análise crítica a partir de três leituras fílmicas de Orfeu. Tese de mestrado, Instituto de Artes, Unicamp, São Paulo, 2003.

CALLADO, Antônio. "Orfeu tirou Tom do piano e Vinícius do país". In: Folha de São Paulo, llustrada, p.6, 14 abr. de 1999.

DIEGUES, Carlos. "A segunda vinda de Orfeu". Entrevista concedida à Maria Lúcia Rangel. In: Bravo! (Rio de Janeiro, maio, 1992, ano 1, n.8.).

"A identidade do Brasil no Cinema de Cacá Diegues". Entrevista concedida a Hermes Leal. Revista de cinema, São Paulo: Editora Kraô, ano 1, n.5, setembro, p. 8-12.

DINIZ, Thaïs Flores Nogueira. "Três versões de Orfeu". "Orfeu negro em cores: mito e realismo no filme de Cacá Diegues. In: Aletria. Belo Horizonte: Centro de Estudos Literários da Faculdade da UFMG, Curso de pós-Graduação em Letras Estudos Literários (FALE/UFNG), n.8, dez.2001, p.34-40.

GODARD, Jean Luc. Cahier du cinema. (Paris) 1960, p. 59-60.

HANCHARD, Evaston Michael. "Legacy of domination", in: New York Times, New York, 3.9. 2000.

JARDIN, Reinaldo. "Consideração em torno da peça Orfeu da Conceição". In: Jornal do Brasil, Rio de Janeiro, 30 de set. de 1956.

LEITÃO, Luis Ricardo. "Dos veces Orfeo - entre Apolo e Dionísio: Vinícius de Moraes y su Orfeu de Conceição." In: Revolución y cultura. (Habana-Cuba, julioagosto, 2000, ano 42 de la Revolución, p.47-8).

MARTINS, Ana Lúcia Lucas. "Orfeu y la favela carioca de Cacá Diegues." In: Revolución y cultura. (Habana-Cuba, julio-agosto,2000, ano 42 de la Revolución, p.49,50.)

MENEZES, Paulo. À meia-luz: cinema e sexualidade nos anos 70. São Paulo: Usp, Curso de pós-graduação em Sociologia/ Ed. 34. 
NAGIB, Lúcia. "Orfeu negro em cores: mito e realismo no filme de Cacá Diegues. In: Aletria. (Belo Horizonte: Centro de Estudos Literários da Faculdade da UFMG, Curso de pós-Graduação em Letras - Estudos Literários [FALE/UFMG], n.8, dez.2001, p.15-24.)

SANTOS, Myrian Sepúlveda dos. "Orfeu Negro: entre fantasia e realidade." In: Cadernos de Antropologia e Imagem. (Rio de Janeiro: Universidade do Estado do Rio de Janeiro, Núcleo de Antropologia e Imagem, 2000-2, n.11, p. 33-47).

SCOTH, A. O. "Rebord in a less romantic Rio, Orpheus seasons samba with rap", in: New York Times, New York, 25. 8. 2000.

VELOSO, Caetano. Verdade tropical. São Paulo: Companhia das Letras, 1997. "Orpheus, rising from caricature", in: New York Times, New

York, 20.8. 2000.

Sobre teatro

PRADO, Décio de Almeida. "O teatro romântico: a explosão de 1930", in: GUINSBURG, J.(Org.) O Romantismo. 4ed., São Paulo: Perspectiva, 2002. RYNGAERT, Jean-Pierre. Introdução à analise do teatro. (Trad. Paulo Neves), São Paulo: Martins Fontes, 1996.

Ler o teatro contemporâneo. (Trad. Andréa M.da Silva),

São Paulo: Martins Fontes, 1998.

ROSENFELD, Anatol. Mito e o herói no moderno teatro brasileiro. $2^{\mathrm{a}}$ ed. São Paulo: Perspectiva, 1982 (Debates, 257).

Prismas do teatro. São Paulo: Perspectiva, Editora da

Universidade de São Paulo; Campinas: Editora da Universidade Estadual de Campinas, (Debates, 256), 1993.

O teatro épico. $4^{\circ}$ ed., São Paulo:Perspectiva, 2002. 
Texto/contexto. $3^{\circ}$ ed., São Paulo: Perspectiva, 1976. \& GUINSBURG, J. "Romantismo e Classicismo", in:

UBERSFELD, Anne. Lire le théâtre I. Paris : Belin, 1996.

Sobre cinema

ARNHEIN, Rudolf. $A$ arte e do cinema. São Paulo: Martins Fontes.

BAZIN, André. O cinema: ensaios. São Paulo: Brasiliense.

BENJAMIM, Walter. "A obra de arte na época de suas técnicas de reprodução”, in: Textos escolhidos (Trad. José Lino Grünnewald ...[et all]. São Paulo: Abril Cultural, (Os pensadores), 1980.

"A obra de arte na época de sua reprodutibilidade técnica".

In: Magia, arte e técnica. São Paulo: Brasiliense, 1986.

BERNARDET, Jean Claude. O que é cinema. 14ª ed. São Paulo: Brasiliense, 2004.

CASETTI, Francesco e DI CHIO, Federico. Cómo analizar un film. Barcelona/México/Buenos Aires: Paidós, 1996.

DEBS, Sylvie. Cinema et Litterature au Brésil : les mythes du Sertão émergence d'une identité nacionale. Paris : Harmattan, 2002.

TARKOVSKI, Andrei. Esculpir o tempo. São Paulo: Martins Fontes, 1990.

Sobre Cinema e Literatura

PENA-ARDID, Carmen. Literatura y cine: una aproximacíon comparativa. Madrid: Ediciones Catedra, 1992.

Sobre canção, rap, samba e carnaval 
CABRAL, Sérgio. Antônio Carlos Jobim: uma biografia. Rio de Janeiro: Lumiar. As escolas de samba do Rio de Janeiro. Rio de Janeiro:

Lumiar, 1996.

CASTRO, Maria Laura Viveiros de. Carnaval carioca dos bastidores ao desfile. Rio de Janeiro: Funarte, 1994.

CUNHA, Maria Clementina Pereira. (Org.) Carnaval e outras festas:ensaios de História Social da Cultura..Campinas: Editora da Unicamp, 2002.

MOURA, Roberto. Tia Ciata e a Pequena África no Rio de Janeiro. Rio de Janeiro: Biblioteca Carioca, 1995.

GARCIA, Walter. "Ouvindo Racinais MC'S". In: Teresa: revista de Literatura Brasileira. (São Paulo: Editora 34/ Universidade de São Paulo, 2003, n. 4/5, p. 167-80).

OLIVEIRA, Jane Souto \& MARCIER, Maria Hortense. "A palavra é favela" in: ALVITO, Marcos \& ZALUAR, Alba. (Org.) $4^{\circ}$ ed. São Pa ulo : FGV, 2004.

PARANHOS, Adalberto. "Os sambistas e a invenção do samba como "coisa nossa". www.samba-choro.com.br 24.10.2006.

SANTOS, Myrian Sepúlveda dos. Mangueira e Império: a carnavalização do poder pelo samba. In: ALVITO, Marcos \& ZALUAR, Alba (Orgs.). Cem anos de favela. Rio de Janeiro: FGV, 1998.

TATIT, Luis. Composições de canções do Brasil. São Paulo: Edusp, 2002. Semiótica da canção : música e letra. São Paulo : Escuta, 1995.

VIANNA, Hermano. O mistério do samba. Rio de Janeiro: Zahar, 1995. O mundo funk carioca. Rio de Janeiro: Zahar, 1998.

WISNIK, José Miguel. O nacional e o popular. São Paulo: Brasiliense, 1982. Sem receita. São Paulo: Publifolha, 2004.

Outras obras consultadas: 
ARISTÓTELES. Aristote : petits traités d'histoire naturelle. $2^{\circ}$ tirage. ( texte établi et traduit par René Mugnier) ; Paris : Les Belles Lettres, 1965.

APOLLINAIRE, Guillaume. Oeuvres poétiques. Paris: Gallimard, 1965.

ADORNO/HORKHEIMER. Dialética do esclarecimento: fragmentos filosóficos.(Trad.Guido Antonio de Almeida) Rio de Janeiro: Jorge Zahar Editor, 1985.

"Lírica e sociedade", in: Textos escolhidos (Trad. José Lino Grünnewald ...[et all]. São Paulo: Abril Cultural, (Os pensadores), 1980. ALIGHIERI, Dante. A divina comédia (em forma de narrativa). (Trad. Cordélia Dias de Aguiar), São Paulo: Publifolha, 1998.

BENJAMIN, Walter. Magia arte e técnica. São Paulo: Brasiliense, 1986.

Charles Baudelaire um lírico no auge do capitalismo. (Trad. José Carlos Martins Barbosa. e Hemerson Alves Batista). São Paulo: Brasiliense, 1995.

BLANCHOT, Maurice. O espaço literário. (Trad. Álvaro Cabral). Rio de Janeiro: Rocco, 1987.

BOSI, Alfredo. O ser e o tempo da poesia. São Paulo: Cultrix, 1983.

FAUSTO, Boris. Historia concisa do Brasil. São Paulo: Edusp, 2001.

FRIEDRICH, Hugo. Estrutura da lírica moderna. $2^{\circ}$ ed., São Paulo: Duas Cidades, 2001.

GUINSBURG, J.(Org.) O Romantismo. 4ed., São Paulo: Perspectiva, 2002.

HOLLANDA, Sérgio Buarque de. São Paulo: Companhia das Letras.

HOUAIS, Antônio. Dicionário Houais da Língua Portuguesa. Rio de Janeiro: Objetiva, 2001.

LEIRIS, Michel. A idade viril. (Paulo Neves). São Paulo: Cosac \& Naify, 2003.

Espelho da tauromaquia. (Trad. Samuel Titan Jr.) São Paulo: Cosac \& Naify, 2001.

MARCUSE, Herbert. Eros e civilização: uma interpretação filosófica do pensamento de Freud.(Trad. Álvaro Carvalho), $8^{\circ}$ ed. ,Rio de Janeiro: LTC.

SOUZA, Gilda de Melo. O tupi e o alaúde: uma interpretação de Macunaíma. São Paulo:Duas Cidades, 1979. 
NIETZSCHE, Friedrich. O nascimento da tragédia ou helenismo e pessimismo. (Trad. J. Guinsburg), 2ed., São Paulo: Companhia das Letras, 2005.

Ecce hommo : como alguém se torna o que é. (Trad., notas e pósfácio de Paulo César de Souza), São Paulo:Companhia das Letras, 2005.

Obras incompletas. $3^{\circ}$ ed., (Trad. e notas de Rubens Rodrigues Torres Filho), posfácio de Antonio Candido, São Paulo: Abril Cultural, 1983.

PANDOLFI, Dulce Chaves \& GRYNSPAN, Mario (Org.) A favela fala: depoimentos ao CPDC. São Paulo: FGV, 2003.

PESSOA, Fernando. Fernando Pessoa: obras em prosa. Vol. único, Rio de Janeiro: Nova Aguilar, 1986.

PLATÃO. O banquete. $2^{\circ}$ ed., São Paulo: Difusão Européia do Livro, 1970.

A República. (Trad. M.Helena da Rocha Pereira) Lisboa:G Gulbenkian, 1980.

ROUSSEAU, Jean-Jacques. Jean-Jacques Rousseau: vida e obra. (Trad. Lourdes Santos Machado) São Paulo:Nova Cultural, 1999 (Os pensadores), v. 1. SHILLER, Fridrich. Poesia sentimental e poesia ingênua. (Trad. Márcio Suzuki), São Paulo: lluminuras, 1991.

SCHOPENHAUER, Arthur. Métaphysique de l'amour, Métaphysique de la mort. (traduit de l'allemand par Marianna Simon), Paris : Editions 10/18, Département d'Univers Poche, 1964

Arthur Schopenhauer: vida e obra. (Trad. Wolfgang Leo Maar e Maria Lúcia Mello e Oliveira Cacciola), São Paulo:Nova Cultural, 1999 (Os pensadores).

STAIGER, Emil. Conceitos fundamentais da poética. Rio de Janeiro:Tempo brasileiro, 1974.

SEVCENKO, Nicolau. Literatura como missão : tensões sociais e criação cultural na Primeira República. $2^{\circ}$ ed., São Paulo: Companhia das Letras, 2003.

RILKE, Rainer Maria. Sonetos a Orfeu. (Trad. Emmanuel Carneiro Leão), $2^{\circ}$ ed. Petrópolis: Vozes, 1994. 
VALLADARES, Licia. "A gênese da favela carioca: a produção anterior às Ciências Sociais", in: Revista Brasileira de Ciências Sociais, v. 15, n.44. São Paulo, outubro de 2000.

A invenção da favela : do mito de origem à favela.com. $1^{\circ}$ ed. Rio de Janeiro: FGV, 2005

VALERY, P. Ouevres. Paris: Gallimard, 1957.

Filmografia:

Orfeu negro, de Marcel Camus (autor do texto: Vinícius de Morais; roteiro: Jacques Viot), 1960.

Orfeu, de Carlos Diegues (roteiro: Carlos Digues, Paulo Lins, Hermano Vianna, Hamílton Vaz Pereira, e João Emanuel Carneiro), 1999.

Os Bandeirantes, de Marcel Camus (roteiro, diálogo e adaptação: Marcel Camus; adaptação e diálogos: Jacques Viot).

Jorge Amado, de João Salles. Documentário, 1995. 